cos 
Digitized by the Internet Archive in 2008 with funding from Microsoft Corporation 
$2^{80}$

208 

MARRIAGE AND HEREDITY 



\title{
Marriage and Heredity
}

A View of Disuchological Evolution

\author{
BY \\ J. F. N I S B E T
}

THIRD EDITION

LONDON

WARD AND DOWNEY

I 903 



\section{PREFACE}

IT is hardly the Author's fault if this book appears to lay claim to being the Manual of a new Social Science. His primary object was to present in a compact form what history, philosophy, science, and even poetry and fiction have to teach on the subjecc of marriage. From the collation of the facts disclosed in many independent lines of inquiry certain leading principles are evolved which may be found to be worthy of attention. Hitherto the physical aspect of evolution has almost exclusively engrossed the attention of scientific men, and the important fact remains unexplained that while there is practically no difference in bodily form and structure between savage and civilised man, the numerous races of mankind exhibit much variety of mental capacity, and are consequently more or less fitted to carry on the struggle for existence. Physically, the savage is sometimes superior to the European, having greater 
muscular strength and greater powers of endurance. Yet the superior mental capacity of the European secures him an easy victory over the savage in whatever field he happens to be opposed to him. The European is the master of the world. By what means has he attained his superiority? Not by physical selection, for not only are the Englishman, the Red Indian, and the Zulu similar in point of physique, but even the evidence of the Egyptian tombs does not warrant us in supposing that within any measurable period of time man was ever physically less developed than now. These considerations prompted Wallace some years ago to put forward the speculative opinion that with the origin of mind in the human race selection with regard to physical form and structure ceased, man as an animal remaining stationary, because all changes in his environment were met by mental instead of corporeal adaptation - that is to say, he made clothes instead of growing fur to suit a particular climate, he learnt to cope with the strength and the agility of other animals by inventing weapons, when food was scarce he produced it artificially, and so on.

The results of an inquiry into the operation of marriage and heredity from the earliest times and 
all over the world seem to bear out Wallace's speculation, and to prove that although physically man now remains unchanged, mentally his development continues. In other words, it would seem that the evolution of the human race has passed from the physiological into the psychological field, and that it is in the latter alone henceforward that progress may be looked for. This fact is especially interesting at a time when the biological theories of Weismann seem to set great limitations upon the variability of species. Whatever may be the case with the bodily characteristics of man, his psychological condition would appear to be highly susceptible to the influence of his surroundings, and what we know of the law of heredity justifies the belief that a mental state comprising an elaborate set of social sentiments is more or less transmissible. The child of civilised parents does not come into the world with the same mental equipment as the little savage. $\mathrm{He}$ is not obliged to work out all social problems de novo. His mind has an hereditary bent which enables hin easily and naturally to fulfil his duties as a citizen. No doubt it is difficult to determine what features in the character of an individual are due to education and what to heredity. Until 
an English child is taken from his mother's breast, and brought up without any intereourse with his kind, we shall never know precisely in what respect he differs at birth, morally, from a little Hottentot. But the presumption in favour of the heredity of sentiment is overwhelmingly great, even in the case of sentiment which has been accumulated within a fewer number of generations than Weismann assigns to the continuity of his Keimplasma.

As regards the method in which the question of psychological evolution is treated in the following pages, objection may be taken to the frequent allusions made to works of fiction. No doubt the evidence furnished from this source as to prevailing currents of sentiment at a given period is inexact and unscientific. But psychology is as difficult to discuss as questions of taste, and an inquirer into the history of popular sentiment, be he as painstaking as he may, can only hope to arrive approximately at the truth. The drama is perhaps after all a more faithful reflex of the popular sentiment of a period than the pages of history; for while the historian may interpret events in the light of preconceptions and prejudices of his own, the dramatist is bound to study and to conform to the feelings of an audience of his contemporaries. The 
subject of the elective affinities is closely allied to that of sexual selection. By more than one authority it is questioned whether the importance of sexual selection was not overrated by Darwin; and there is in fact great difficulty in explaining upon the score of utility alone such variations of structure as the peacock's tail, while in all species, including man, the inferior types find partners without difficulty, and are, upon the whole, as productive as the superior ones. It would thus appear that sexual selection is swallowed up in natural selection. At the same time, mon may be trusted to reason about their own feelings more accurately than they can about those of any other species, and the existence of sexual preferences in the human race will hardly be denied. In connexion with a theory of psychological evolution, the elective affinities which are a form of mental selection acquire a new and scientific importance. 



\section{CONTENTS}

\section{CHAPTER I}

What IS Marriage? . . . . . . I

CHAPTER II

The Growth of the Tie $\quad . \quad . \quad . * 14$

\section{CHAPTER III}

Christian Marriage and Morality .,$\quad 35$

CHAPTER IV

Chivalry and Platonic Love $\quad$. $\quad$. 58

CHAPTER V

The Law of Heredity . . . . . 71

\section{CHAPTER VI}

Transmission of Physical and Mental Charac-

TERISTICS . . . . . 


\section{CHAPTER VII}

Throwing Back and the Metamorphoses of

PAGE HEREDITY

\section{CHAPTER VIII}

Relative Influence of the Male and Female

PARENT . . . . . . .

CHAPTER IX

Consanguinity

.

CHAPTER X

Blue Blood •

The Procreation of Genios .

\section{CHAPTER XII}

Beauty and the Elective Affinities

\section{CHAPTER XIII}

Polygamy

\section{CHAPTER XIV}

The Family Insmincts

\section{CHAPTER XV}




\section{MARRIAGE AND HEREDITY}

\section{CHAPTER I}

WHAT IS MARRIAGE?

IT may be said generally of marriage that although associated in Christian countries with a religious ceremony, it is subject to the same process of development as any other social or political institution, and is to be judged by the same standards, namely, those of usefulness and expediency. No fixed laws of morality or virtue are to be found in human nature. The Darwinian theory that all animal instinct is governed by physical conditions may not be so confidently accepted at the present day as it was a few years ago, but there is nevertheless strong evidence that many of the mental states of a given people-moods or dispositions loosely called instinctive-are induced 
by circumstances and then fixed by heredity. Because such psychological developments are unaccompanied by any physical changes of structure in man, it would be rash to conclude against the possibility of their occurring. So staunch a Darwinian as Wallace has assumed that the mental adaptability of man will henceforward enable him to meet all changes in his surroundings without the aid of physical selection; ${ }^{1}$ and the theory of a psychological process of evolution superposed upon the physical has certainly much to recommend it.

Such sentiments as the detestation of marriages between brother and sister, esteem for chastity, and the modern respect and deference shown to woman as the "weaker vessel," are all sufficiently deeprooted in the Englishman's nature to be called in-

I "From the time when the social and sympathetic feelings came into active operation, man would cease to be influenced by selection in his physical form and structure. As an animal he would remain almost stationary, the changes in the surrounding universe ceasing to produce in him that powerful individnal effect which they exercise over other parts of the organic world. But from the moment that the form of his body became stationary, his mind would become subject to those very influences from which his body had escaped. Every slight variation in his mental and moral nature which would enable him the better to stand against adverse circumstances would be preserved and accumulated."-Paper, "The Action of Natural Selection on Man," by A. R. Wallace. 
stinctive; but they are none of them to be found among primitive races, where the status of women is extremely low. They are the outcorne of social and religious influences falling within the range of history. It is certain that the important group of sentiments comprised under the term chivalry or platonic gallantry, for example, was but little known to the Greeks and Romans, and that it has in the main been developed under the influence of the purity doctrines of the Christian Church. By those doctrines, preached for so many centuries, our moral nature has been profoundly influenced. The modern European has the chivalrous instinct bred in the marrow of his bones, so much so that there are probably few roughs in Christendom so abandoned as not to make way for a lady on occasion-a mark of politeness unfamiliar alike to the noble savage and the polished Oriental; and the growth of this feeling has had the immensely important result of giving women a voice in the disposal of their affections. If the establishment of monogamous marriage did much for the welfare of womankind, that curiously complex sentiment of comparatively modern growth which demands that a man shall woo his wife and neither buy nor capture her has done still more. 
That habits of mind, induced by circumstances and fixed by heredity, are the true basis of morals, may be proved by a simple reference to facts. As the circumstances of one race differ from those of another, so do the prevailing standards of right and wrong vary all over the world. The morality of the East is not that of the West; and even neighbouring countries like France and England set up different standards of propriety. Nor is it merely a superficial set of sentiments that are affected in this manner, but some of the most deep-seated of our nature. Let us take, for example, the sense of shame. A Mahomedan woman who cannot be persuaded to unveil her face in the presence of men will think little of displaying the whole of her leg or bosom. Respect for property is always deeply engrained in a people who have been strictly policed for centuries; their honesty becomes innate. Subject races habitually resort to methods of warfare that would be repugnant to their conquerors. Lying is a despicable vice in England, but among the Bengalese little or no discredit attaches to it.

To return to marriage, there is not a single sentiment of the modern European bearing upon the relations of the sexes that has not been or is not habitu- 
ally violated by some section of the human family. Among the ancient Egyptians brothers and sisters were allowed to marry. The ancient Persians saw no harm in a son marrying his mother. In Babylon women were expected to sacrifice their virtue in the temples previous to marriage, and a modified form of this custom has been found in the Balearic Islands, where, on the occasion of a wedding, the bride used to belong for one night to all the guests. On the west coast of Africa a son generally inherits his father's wives, with the exception of his mother. The Krooman, however, goes further; he inherits his mother with the rest. The practice of husbands lending their wives to guests and friends exists among the aborigines of North and South America, also in Greenland, Siberia, Central Asia, Africa, Australia, and Polynesia. It was not unknown in Rome. Cato lent his wife Martia to his friend Hortensius, and upon the death of the latter took her back to his household. Certain New Zealand tribes meet at intervals and exchange wives.

Polyandry, or the custom of one woman having several husbands, exists in Thibet, Ceylon, New Zealand, and Polynesia. In Thibet the several husbands of a woman are usually brothers. In such 
promiscuous relationships jealousy, in the European sense of the word, appears to be unknown. Hepworth Dixon found it among the Mormon wives in Salt Lake City, but those unhappy women were all of English or European birth, and were therefore influenced by European training. A traveller who visited Thibet in the last century, and who found, to his surprise, that the natives "clubbed together in matrimony as in trade," says disputes occasionally arose as to which husband was the father of a particular child, but were settled by a judgment of the mother or by a comparison of the child's features with those of its supposed parent. Dr. Livingstone states that the women of an African tribe, on hearing that a man in England could only take one wife, declared that they would not live in such a country. The inmates of Mahomedan harems live together tranquilly, and think it a sign of neglect on the part of their husbands if they are not jealously guarded.

Another set of customs wholly at variance with European notions relates to what may be called marriage on approval. Balzac observes "that the idea of taking a wife on trial will make more wise men reflect than fools langh." He was not aware 
that experimental marriage has been very extensively practised. In one of the aboriginal tribes of India marriages take place at a fixed period of the year, when all the candidates, male and female, live together for six days and then pair off. The young Turcoman carries off a girl and lives with her for six weeks, at the end of which time, if she has found favour in lis eyes, his friends open negotiations with her parents for a marriage in regular form. In Ceylon marriages are provisional for a fortnight, and are then either annulled or confirmed. In the Andaman Islands marriage lasts only till a child is weaned, when each party seeks a new engagement. The Hussaniyeh Arabs have what Lubbock calls "three-quarters marriage," a woman being expected to be faithful to her husband for three days out of four, but on every fourth day being free to do as she chooses. Among the tribes of Southern India a young woman of sixteen or twenty is married to a boy of five or six, but lives with some other adult male, usually a relative. Her children are fathered upon the boy, but he in turn, when he grows up, has the privilege of begetting children for some other youthful husband. In Japan it is no stain upon a girl's name, or any impediment to her marriage, that she should hire 
herself out for a term of years to the keeper of a house of ill-fame, in order to retrieve her father's fortunes. The Hindu law does not recognise impotency as a bar to marriage. The wife of a Hindu eunuch is allowed to have a son and heir by a male friend of the husband's duly appointed to represent him.

Marriage by capture has been general all over the world, and traces of it survive among ourselves in the throwing of the slipper, originally no doubt a defensive action, and in the providing of a "best man," who was, of course, the bridegroom's stoutest supporter in his attempt to carry off the bride from her protectors. In its early form the capture is real, violence and stratagem being used by the bridegroom. Thus, among the Australian blacks, a would-be husband awaits his opportunity to pounce upon the unsuspecting object of his attentions. Then with a blow of his club he stuns her, and carries her off senseless to his tent. Or several men combine to capture wives from a neighbouring tribe. Stealthily approaching the camp by night, they twist their spears in the hair of the women sleeping by the fires, and under threat of instant death if they give the alarm, compel them to follow them. In Fiji the seizure of 
women in war is conjoined with cannibalism, the female captives being turned into wives and the men into food. Among the early Greeks and Romans wives were captured, and a similar practice obtained among the Jews.

It is only among the lowest races that actual violence in the capture of wives is now resorted to. From being real the process of capture has become feigned, and in this secondary form may be found in all quarters of the globe. The practice exists in a transition state among the Bedouins. After a marriage has been agreed upon, the bride offers a real resistance to the bridegroom. The more difficult she is to capture, the more she is applauded. Sometimes she escapes into the mountains and has to be hunted for for days, being secretly supplied with food by her relatives. Darwin finds in the practice of feigned capture examples of the process of sexual selection on the part of women as well as men, the women only allowing themselves to be taken when their pursuers are to their liking. Among the Calmucks a girl sought in marriage is mounted upon a horse and rides off at full speed, her lover pursuing, and whether she is caught or not depends entirely upon the state of her feelings. A similar practice is seen in Pata- 
gonia, the Malay Archipelago, and in North-eastern Asia. The girl in these cases is not put upon horseback, but hides or runs, or otherwise asserts her freedom of choice in the matter of a husband. Among the blacks of New Zealand the husband has to remove his bride by force. If she dislikes him, the task is a tremendous one; it is the work of hours dragging her a hundred yards. But if she has a partiality for her captor, her resistance is easily overcome. The feigned capture of brides existed in Wales until the last century, the bridegroom's friends and the bride's engaging in a mock scuffle. This ceremony is witnessed also among tribes inhabiting the plains of India. ${ }^{1}$

The process of transition from the primitive forms of marriage to that practised by Christian communities is a very slow and gradual one. Its earlier stages we can only guess. We may suppose that in tribes living promiscuously men would prefer certain women to others, and would try to hold them against all

1 The foregoing and other singular mamiage customs are described in MacLennan's Primitive Marriage; Sir J. Lubbock's Origin of Civilisation; Huth's Marriage of Near Kin; Wilkinson's Ancient Egyptians; Banerjee's Hindu Law of Mlarriage; Hepworth Dixon's New America; Lane's Modern Egyptians; Darwin's Descent of Man; and Kames's History of Mran. Gibbon and Herodotus also furnish examples. 
comers. A sense of ownership in wives, as in cattle, weapons, or other goods, would thus arise, and it would become necessary to stamp them with the seal of possession. Hence the adoption of a marriage ceremony of some sort, however rude. Purchase probably followed upon capture. Lubbock has invented the term "communal marriage" to express the order of things under which a woman is supposed to belong to her tribe and not to any individual, but the distinction between this and promiscuous intercourse is rather fanciful. The idea of communal rights may help to explain the Babylonish and Balearic customs above referred to. It may also have been at the bottom of a strange Peruvian notion that a husband was disgraced if his wife on her marriage day proved to be a virgin. MacLennan opines that marriage by capture in the form of exogamy, or the practice of one tribe raiding another and carrying off its women, was due to a scarcity of females. But later writers disagree with him upon this point. Lubbock believes that the system of capture was originally adopted by chiefs and others as a means of obtaining exclusive possession of a wife-as a form of marriage, in fact, which did not interfere with communal rights. Herbert Spencer thinks that the possession of foreign wives 
would be regarded as a mark of prowess in a tribe, and that it would become every warrior's ambition to capture women as a Red Indian captures scalps. Another inducement to the establishment of a form of marriage is probably the desire of men to know their own particular children. This feeling would grow up with the recognition of property. The pleasures of paternity are unknown to men living under the most primitive conditions. At first children are affiliated not to particular couples, but to the tribe; their kinship through females is recognised, children being sure of their mother although not of their father. In such circumstances we may suppose it is felt as a hardship that men who have accumulated property should not be able to leave it to their sons, and the next step towards the constitution of society, as we know it, is the exclusive appropriation of wives.

Some form of marriage is always well established before religion intervenes in the ceremony. Unquestionably, however, religion has profoundly influenced the marriage customs of the world, sometimes for good, more often for evil. The establishment of caste in India had the advantage of checking promiscuous relationships to begin with, but its unbending rules have since been productive of much abuse 
and oppression. Polygamy, as sanctioned by all the great religions of the East, is an undoubted evil, sapping the vitality of the races brought under its sway, and unfitting them for the task of holding their own in the world. On the other hand, the influence of Christianity, with its practical equalisation of the sexes, has been healthful and regenerative. Monogamy, upon which the progress of the human race so largely depends-we shall see in due time how -was not invented by Christianity, but it gained enormously from the support of Christian doctrine. That marriage is a "divine institution" is true only in the sense in which every institution, whether monarchy or universal suffrage, is divine. Its various forms, as the reader will have gathered, are essentially so many convenient arrangements for the distribution of wives and the rearing of children, and by keeping this fact before us we shall be able to appreciate not only the development it has already undergone, but that of which it is still susceptiblea matter of some importance to mankind. 


\section{CHAPTER IT}

THE GROWTH OF THE TIE

Is Greece and Rome were sown the seeds of much that goes to make up the civilisation of to-day, in letters, art, and law, and in the long stretch of centuries that elapsed from Homer to the Emperor Constantine marriage underwent great changes. The Greeks never fully attained to the modern conception of mutual fidelity on the part of husbands and wives; they made this enormous advance upon their barbarian neighbours, however, that marriage was intimately bound up with citizenship, and that great store was set upon matronly virtue, which was ensured by the seclusion of wives in pretty much the same fashion as that obtaining at the present day in Eastern countries. Love appears to have had little to do with marriage, for the few individual instances of conjugal attachment that have been handed down to us did 
not constitute a rule. Wives were kept for the procreation of citizens; the honours of society were reserved for the courtesan.

In Athens, at its most brilliant period, prostitution was the only career open to an ambitious woman. Marriage was a species of domestic slavery; it was the courtesan who was consulted by the philosopher, and whose beauty inspired the poet and the sculptor. The romantic love that enters so largely into our modern life was consequently unknown in Athens, and is not reflected in any degree in Greek literature. Homer's Penelope, for example, is a stately matron, faitlful to her lord throughout his twenty years' absence, but otherwise cold and statuesque. The return of Ulysses is not the signal for any outburst of pent-up affection or tenderness in the household. Penelope is calm and collected, and her duty is fulfilled in extending to her long-lost husband a dignified and submissive welcome. Imagine how a modern poet would treat such an event! With what emotion, what tears, what embraces, would the longseparated couple throw themselves into each other's arms! To Eschylus, again, love is a sentiment unworthy of a poet's attention. He lauds the eternal principle of fecundity; but his personages neither 
feel nor speak of love as a passion. The same austere views are expressed by Sophocles. Hæmon, it is true, dies upon the tomb of Antigone, but from his previous harangues it would be difficult to gather that he had any affection for that heroine. Indeed, when reproached by his father with being a woman's slave, he repels the suggestion as an insult. How differently Racine, as a modern poet, makes Achilles speak in defending Iphigenia! A still more striking proof of the divergence existing between the Greek and the modern view of love is to be found in comparing the Antigone of Sophocles with the Kabale und Liebe of Schiller. Ferdinand and Luise, like Hæmon and Antigone, die together, but whereas the Greek hero talks politics, the German lover proudly vindicates the claims of passion. "Father," says Ferdinand, "there is a region in my heart where your authority has never penetrated; do not dare to enter there!" Then after Luise's death, conducting his father to her body, he exclaims: "Look, balbarian! gloat over the results of your tyranny. Death has written your name upon that face, and there it shall be read by the destroying angels. ... May such a figure as this be by your tomb when you rise again, and on God's right hand when you 
are judged." No ancient addresses language of this kind to his father.

In Greek tragedy love is admitted only as a form of relentless fate. It is not allowed to enter into family life in the form of passion, nor is woman's modesty respected as the public sentiment of the moderns requires it to be. Both Euripides and Racine have treated the story of Andromache, each from the point of view of his own age. The Greek poet depicts the maternal love of his heroine, but cares nothing for her other womanly attributes. From being the spouse of the noble Hector, slain in battle with the Greeks, Andromache becomes the slave of Pyrrhus. But her past rank entitles her to no consideration; on the contrary, she is made to perform the most menial offices, and as a matter of course shares the bed of her captor. And her fate would seem to have been entirely agreeable not only to Greek notions, but to the spirit of Roman civilisation as well; for Virgil, while accepting the views of Euripides, represents Pyrrhus as afterwards marrying Andromache to one of his slaves, Helenus, another Trojan captive, and the brother of Hector.

Against such humiliating treatment of a noble woman it never occurred to the Greck or Roman 
public to enter a word of protest. Racine had to proceed upon different lines. His Andromache is a prisoner also, but an honoured one. Pyrrhus loves her, but he is discreet and respectful in his attentions, and shrinks from the thought of outraging her sense of delicacy. And to the French Andromache this submissiveness on the part of her conqueror appears perfectly natural. Had Racine followed his Greek model, and allowed Pyrrhus to exercise the rights of a master over his female slave, he would have raised a storm of indignation among his audience. The unchivalrous character of the Greeks is further exemplified in their treatment of the passion of jealousy. The growth of jealousy among a people is a sign of increasing esteem for the female sex. We do not mean the jealousy which prompts the lower animals to fight for the possession of their females, but that higher sentiment which concerns itself with a woman's honour. Among the lowest races jealousy of this stamp is unknown. There is atways some progress made when female virtue is guarded by bolts and bars and veils and a rigorons surveillance, but it is only in the most advanced communities that men are scrupulous about the fidelity of women, and at the same time willing to trust to their sense of duty. 
In the main the confidence which women now clain and receive is not misplaced. Chastity, like benevolence and other virtues, has been much discussed by rival schools of philosophy, the adherents of the Intuitive system believing it to be the outcome of an innate consciousness of right and wrong in the female nature, and the Utilitarians viewing it as a matter of prudential calculation on the part of the individual. Upon such questions the modern theory of evolution, which treats instinct as an inherited custom, has thrown a flood of light. We now know that the Intuitives and the Utilitarians alike had some grasp of the truth. Chastity has become instinctive among women in highly civilised races, and it has done so precisely in the same way as honesty becomes instinctive in a people who have been lawabiding for many generations. Both virtues, which are peculiar to the human race, grow up simultaneously with the notion of property, chastity being demanded of women as soon as men develop the desire to transmit property to their children.

From very ancient times men have been uncompromising upon the subject of the adultery of their wives, death being often the penalty attached to the crime; whereas it is quite a modern and academic 
idea that men should be punished for infidelity. And here we may observe that the modern enthusiasts who insist upon men being judged by the same standards of morality as women, especially with reference to breaches of the marriage vow, wholly mistake the fundamental conditions of the problem. That queen of France who threw in her husband's face the scathing taunt-"I can produce princes, you nothing but bastards," touched the matter, so to speak, with a needle. The purity of the family is bound up with the chastity of the wife. The husband's infidelity does not necessarily affect his home interests.

Had James I. been the son of David Rizzio, Queen Mary's fault would have been infinitely more farreaching in its effects than the profligacy of any of the Stuart kings. That women can be strongly jealous is true, but their jealousy springs from a different cause from that of men. It is analogous to the instinct of self-preservation. The wife is jealous because she feels the necessity of defending her position; and her sufferings can be assuaged, to some extent, by the assurance that her rival is inferior to herself in attractiveness, and has no chance of supplanting her in her husband's affections-a motive which cannot possibly weigh with a jealous husband. Most women are, no 
doubt, prepared to deny that their jealousy has so prosaic a basis as self-interest, and they are so far right that they are not consciously swayed by that motive.

The truth is that in both sexes jealousy has long become instinctive, and its true origin is consequently obscured or lost sight of. The jealousy of women remains none the less essentially different in its purposes from the jealousy of men. In the one case, the instinct is designed to ensure protection to the woman who is rendered dependent by child-bearing, and in the other its object is to regulate the paternity of children. The husband's infidelity can be repaired and forgiven ; the wife's, on the other hand, as regards its consequences, is irreparable. It is the merest sophistry therefore to argue that the offences of husbands and wives ought to be equalised before the law, and so truly is this felt by women that they themselves are the severest judges of an erring sister, while to an erring husband they are wondrous kind.

What we have said of the growth of the instinct of chastity explains the futility of the arguments advanced from time to time to condone the position of fallen women, and to secure their recognition in society as victims rather than sinners. The fallen woman is one who has swerved from a standard of right and 
wrong erected by society for its own protection. So long as this standard exists, the claims of the modern courtesan to consideration will stand upon no higher a level than those of the defaulting cashier.

The Greeks attained to that state of social advancement in which wives are secluded. They did not, like the Romans, rise beyond it. They never dispensed with the gynæceum-an institution closely resembling the Mahomedan harem. But we have no right to blame the men of that age for their treatment of their womenkind. The gynæceum was an educational stage in the experience of women the benefits of which we now enjoy, and it is very probable that if Greek husbands had trusted to the sense of honour of their wives, which was then only beginning to be cultivated, they would have leant upon a broken reed. ${ }^{1}$

In Greek literature jealousy is frankly represented in the initiatory stage that we have endeavoured to

1 Confidence in female virtue was of slow growth. In the fourteenth century French wives were not allowed to receive visits from men except in the presence of their husbands. Anne of Brittany introduced the fashion of ladies appearing publicly at Court. This faslion was afterwards carried into England, but even down to the time of the Revolution English women of rank seldom appeared in the streets without a mask. 'The modern veil or "fall " is probably a survival of the custom. 
describe. Whether among wives or concubines or courtesans, it is little more than a rivalry of interests. The Andromache of Euripides sententiously reminds Hector that for his sake she has loved the women that he loved, and even suckled the children they have had by him. Hermione's jealousy of Andromache is inspired less by Pyrrhus's attentions to his distinguished captive than by the threatened loss of her position as the head of his household. As much may be said of the jealousy of Dejanira in the Trachinice of Sophocles. It does not manifest itself until she learns that the captive Iole is not an ordinary concubine of her husband's, but one respecting whom he has special views. In the comedies of Menander, who flourished late, love and jealousy found fuller expression than in the ancient tragedies, judging by the fragments of his work that remain and the Latin adaptations of his plays by Plautus and Terence. But his stories deal chiefly with the amours of young libertines and courtesans, from which anything like elevated sentiment is necessarily excluded.

The supremacy of the courtesan in Athenian society is easily accounted for. The wife held her position by virtue of the law regulating the pure national extraction of children, and marriages were arranged 
upon the basis of the dowry, the man seldom seeing his bride until the day of the ceremony. Judging by the comedies, which then, as now, we may suppose, reflected the feelings of society with tolerable fidelity, the wife was often a scold and a shrew, apt to presume upon the accession she had brought to the family wealth. In any case, she was condemned to a narrow round of domestic interests, which she shared with her husband's concubines. The courtesan, on the other hand, lived an unrestricted life, and acquired a knowledge of the world that made her an interesting companion. Her house was a literary and fashionable resort. Socrates and Pericles frequented the society of Aspasia. Theodota, another famous courtesan, exercised great political influence, and was instructed by Socrates in the art of enslaving her clients.

The decay of the Greek civilisation has long been a standing wonder to the historian and the moralist. We believe that the mystery may to some extent be explained by the rigour of the Athenian marriage law, which produced, in a comparatively small community, a system of in-and-in breeding. With this subject we deal in a subsequent chapter upon "Blue Blood," where the evils of caste are exemplified, particularly in the case of royal families and aristocracies. 
That Athenian society was essentially a caste, and a most exclusive one, is proved by the well-known oration delivered by Demosthenes ${ }^{1}$ in the case of the girl Neaera, who, not being of pure Athenian birth, was denied the honours of citizenship. We need only add here that the comparison of Athenian society to a neuropathic family, which, receiving no sufficient infusion of healthy blood, wears itself out in a given number of generations, is supported by the strange fact of the prevalence among the most cultured Greeks, including public men of the highest eminence, of the vice of unnatural love. Upon this subject Lecky and other modern writers have speculated rather wildly, but there is now no doubt that the perversion of the sexual instinct is a disease belonging to the epileptic group, and denoting a considerable degree of nervous degeneration in the individual. ${ }^{2}$ In the case of Greece, probably,

1 There is some doubt as to whether Demosthenes was the orator of the occasion, but the point is immaterial to the present argument. The orator speaks of the license accorded to husbands in these terms: "We keep mistresses for our pleasure, concubines for constant attendance, and wives to bear us legitimate children, and to be our faithful housekeepers."

2 Cotard, "La Perversion du Sens Génital," Archives de Neuro. logie, 1884.

There is a striking passage in Ribot's Hérédité Psychologique with reference to the decadence of the Greeks. "The organic causes of 
the scarcity of free women was responsible in part for the evil, which in that event may still be regarded as Nature's penalty for a vicious law.

The Roman civilisation followed closely the lines of the Greek, the austere manners of the republic giving place to the grossest license under the empire. It is no part of our task to describe the frightful iniquities of Rome in the time of the Cresars-the public orgies of vice and the shameless obscenity of literature. We refer to this subject only to say that from these evils good resulted in a strangely unforeseen manner, and that they were the cause of what may be regarded as an important step in evolution as affecting marriage and the constitution of society. Roman marriage, like the Greek, began by being a civil obligation, a means of recruiting the population of the state with citizens of pure extraction. Two

this event," the writer observes, "the most astonishing in history, may long continue obscure, but in following step by step a degeneration which lasted a thousand years, in seeing in their works of art the plastic talent of the Greeks grow stiff and lifeless, their imagination become stunted, and their great men dwindle into mediocrities, we seem to feel beneath the visible and palpable facts with which alone historiaus concern themselves, the slow, steady operation of natural causes among these millions of human beings who deteriorated withont knowing it, each generation transmitting to its successor in an increasing measure the germs of decay." 
solemn forms of marriage were practised, Confarreatio and Coemptio, both partaking of the nature of the modern mariage de convenance, inasmuch as the inclinations of the parties were subordinated to considerations of duty or expediency. There was no pretence of affection in these unions, which were established upon the basis of the dowry and the maintenance of caste. The Roman matron, it is true, was treated with more consideration than the Greek. Although to some extent secluded, she was allowed to preside at her husband's table, and was taken to the public festivals. But the results of the system of political marriage were pretty much the same in both communities. In Rome, as in Athens, the husbands of dowered wives-wives qualified as to citizenship, but deficient, it might be, in personal attractions-sought consolation in the society of concubines and courtesans, and with the growth of luxury and of the practice of importing female slaves, the corruption of public morals went on apace.

All experience shows the evil influence of the mariage de convenance, whether in its ancient or in its modern forms, the case of the Latin races of to-day conveying the same lesson as that of ancient Rome. Whenever men are debarred from freely choosing their wives, morality is lax. Seeing how lightly the 
marriage tie is esteemed in Southern Europe, some writers have concluded that a hot climate stimulates the passions ; ${ }^{1}$ but it is impossible to maintain such a theory in face of the fact that the Red Indians of North America and the Esquimaux of Greenland, both living in extremely cold latitudes, are as licentious as Frenchmen, Spaniards, or Italians. The drama is a good index to the views of a people upon certain questions of morality. Authors may choose their heroines upon other principles than they choose their wives, but their popularity necessarily depends upon the fidelity with which they reflect the inner sentiment of the society of their day. In France, where the mariage de convenance prevails, the stage has never ceased to rail at matrimony, and to exhibit the freer relations of the sexes in a favourable light; whereas in England, where the dowry system is all but unknown, the dramatist has usually regarded marriage with a benevolent eye. ${ }^{2}$

1 This fallacy is an old one. It appears to have been first put forward by Montesquieu. Lecky, who has been singularly unfortunate in some of his speculations, adopts it in his History of European Morals.

${ }^{2}$ Legouve in his Histoire Morale des Femmes exposes the evils of the mariage de convenance as practised in France. The time of the engagement, he observes, is shortened as much as possible lest the young people should get to know and dislike each other. They are 
In the times of the republic, Roman sentiment had already declared itself against marriage. The dowered wife, with her arrogance and her shrewishness and with her man of business, whose authority is often opposed to that of the husband, is a constant subject of satire in the comedies of Plautus. Sometimes the unhappy husband is represented as scheming with a slave, in order to deceive his wife and procure money wherewith to buy a pretty concubine, while the vixen overhears the plot, together with sundry uncomplimentary references to her ugliness, her age, and her temper. Sometimes a noble character in the piece pointedly condemns the dowry system. Compared with the wife, the puella or concubine of Plautus and Terence is an estimable character, self-respecting and faithful to her master for the time being, despite the evil counsels of the meretrix or courtesan, or possibly of a calculating mother. In many cases, no doubt, the lot of the concubine was too shifting to allow of the growth of much tender sentiment either in her own bosom or in that of her successive masters, but there were exceptions to the rule. Terence makes

never allowed to see each other alone, and the young man fulfils his duty as a fiancé in paying a few ceremonious visits to his bride and sending her daily bouquets ordered once for all at the florist's. 
one of his courtesans say to a puella: "Our lovers care only for our beauty; when that fades their fancy passes to another. But with you it is different. Once you meet with a lover who resembles you in disposition he becomes attached to you, and thenceforward your happiness is assured."

This brings us to the great saving clause in the constitution of Roman society - the growth of a third form of marriage, called Usus, which was a contract without any formal ceremony, or, in other words, marriage by habit and repute. As a species of concubinage, terminable at the will of either party, Usus seemed little likely to exercise a beneficial influence, and it did certainly produce great instability in the marriage relation. There were women in Rome who could reckon, to their credit or discredit, as many as eight or ten past husbands, and St. Jerome tells us of one being married to a twenty-third husband, who had himself got rid of his twentieth wife. But like that slight variation in the habits of a species which in evolution leads to the most important metamorphoses, Usus was destined to revolutionise the morals of the world. Latterly it became the general form of marriage in Rome, and whatever its drawbacks may have been, it possessed certain great and incontest- 
able advantages. It implied free choice on the part of the contracting parties, which marriage by family arrangement did not; it secured the independence of women, who were allowed to hold property in their own right; it played a large part in the conversion of the empire to Christianity, throngh the influence of the female converts, who, under the old patrician systems of Confarreatio and Coemptio, would have been powerless; and it paved the way for the Christian doctrine of monogamy. To Usus were due those noble examples of conjugal love so conspicuous amid the general corruption of Roman society-wives who followed their husbands upon distant campaigns, and even refused to survive them, and couples so passionately attached to each other that their sarcophagi were adorned with a medallion representing them clasped in each other's arms.

Still, the Romans never fully entered into the sentiment known to the moderns as romantic lovethat ineffable captivation of the higher senses which prompted the remark of Proudhon: Chez les ames d'elite, l'amour n'a pas d'organes. Chastity was reverenced in theory but not in practice. There was a custom that a virgin should not be put to death, but it was deemed to be complied with if the 
victim was deprived of her virtue upon the scaffold by the executioner. ${ }^{1}$ The poets of the Augustan age sing of love, but their passion is certainly not entitled to rank with that of La Nouvelle Hélö̈s. Let us glance at the testimony they bear to the morals of the society they lived in. Ovid instructs his mistress Corinna in the art of deceiving her husband, but soon has the mortification of feeling that his lessons are turned to the advantage of a rival or rivals. Quarrels, reproaches, blows, tears, and forgiveness ensue. Then he reflects that he himself is as faithless as Corinna, but infidelities on both sides are no bar to a renewal of the lovers' transports. The poet's next grievance is that the lady's husband is not sufficiently jealous. Presently this hardship is remedied, but it soon gives place to another, which is that Corinna does not even take the trouble to disguise her numerous intrigues. And so forth. Corinna is supposed to have been Julia, the daughter of Augustus. The amours of Propertius are not less chequered. He sings the praises of Cynthia, who was a Roman lady named Hostia. Faithless himself, Propertius has speedy reason to reproach his mistress with the same failing. She goes off with a soldier; he weeps and trusts she may be happy. So much

1 This occurred in the case of the daughter of Sejanus. 
love deserves a recompense. The lady throws over the soldier and returns to the poet. He is delighted, and thanks Apollo and the Muses. But his bliss is of short duration; he discovers that he has rivals. He forgives Cynthia her infidelities, however, and raves about her beauty, her elegance, and her accomplishments. Soon he has reason to change his note. Cynthia's amours are the talk of the town. He leaves her, but resumes his chain. It is now her turn to be jealous, and Propertius recognises that he is in truth a sad dog. Once more the tables are turned upon the lover, who seeks consolation in the wine-cup. Another reconciliation is followed by further scenes, and the climax is reached when Cynthia makes the poet the laughing-stock of her numerous rivals, death then cutting short her follies. Tibullus confesses to three important attachments, all unfortunate. Delia, Nemesis, and Neaera vie with each other in venal or capricious excesses, constant only in their inconstancy. All due allowance being made for literary embellishment or exaggeration, the loves of the Augustan poets, it must be confessed, present a sorry spectacle. No modern writer would own to being inspired by, or would dare to vaunt the charms of, such women as Corimna and Cynthia. The Romans made an adrance 
upon the Greeks especially in admitting Usus as a form of marriage, and thereby acknowledging the individual rights of women. But sentimental regard for female honour, with all that that implies in the constitution of the family and of the community at large, was unknown in Rome, or existed only in the germ. Society has left far behind it the ideas of the Augustan age in regard to the relations of the sexes, and it now behoves us to trace the route by which it has travelled. 


\section{CHAPTER III}

\section{CHRISTIAN MARRIAGE AND MORALITY}

AMID the diversity of marriage customs in the world we can perceive a strong tendency in favour of the singleness of the union, due perhaps to the fact that the sexes are as nearly as possible equal in numbers. The statistics of civilised countries show a steady proportion of something like 104 male births to 100 female, the excess of the former being designed to repair the greater mortality of males occasioned by the struggle for existence.

In the prime of life the equilibrium of the sexes is fairly established, although, as the result of migration, there may be found to be an undue proportion of men in one part of the world and of women in another. Hence monogamy is the rule even where polygamy is sanctioned by law and religion. It is, in fact, a necessity. 
In polygamous and licentious communities the sensual appetites of men are ministered to by the transference of women from one master to another, but this custom is counteracted by the impulse of the mother to cling to the father of her child, and by the repugnance of men themselves to promiscuous families. The family instincts may of course be overruled, as they were in Rome, where, in the time of Augustus, it was thought expedient to pass enactments against celibacy and to offer special privileges to the fathers of three children. But the race that persistently disregards Nature's laws incurs the penalty of decay and extinction. It rarely happens that this drastic remedy is carried out to the full, as it appears to have been in the case of the Athenian civilisation. In the most abandoned communities there are never wanting philosophers and fanatics to plead for asceticism or moderation. Plato and Pythagoras preached in vain to the Greeks, but they exercised an important influence in the world by paving the way for the regenerative doctrines of Christianity. Other causes operated in the same direction. We have seen how Usus grew up in Rome as a corrective to the highly artificial and pernicious system of political marriage. Voluntary unions imply a certain freedom of choice on the part 
of women, and this is usually employed to strengthen the nuptial tie. The Roman wives, as soon as they were enabled to hold property in their own right, became their husbands' most inexorable creditors, and by that means secured the fragile bonds of Usus. It is true that Roman husbands sometimes repudiated a wife with a small fortune in order to take another with a larger one-Cicero is said to have done sobut the wife's property, for the most part, had a steadying effect upon marriage. This appears to have been the case also among the ancient Egyptians. In marriage settlements of the Ptolemaic period, discovered in the tombs, it is stipulated that if the husband takes a second wife he shall pay a fine to the first. And in polygamous countries at the present day, where a husband has the right to put his wife away whenever he pleases, the dowry is the woman's sole guarantee against divorce.

While Rome was preparing itself for the reception of the Christian doctrine of marriage, the barbarian peoples of the North were drifting equally into monogamy. History knows nothing of the influences that operated among them, but we may infer that they were similar to those we have traced among the heathen communities of the South. At all events, 
when Cæsar's legions carried the Roman eagles into Northern Europe, they encountered men who had nothing to learn from their conquerors in point of morality, but, on the contrary, had much to teach them. The German wife, according to Tacitus, was the helpmate of her husband, at home and in the field, in peace and in war. Heroines and priestesses were highly honoured. Each nation of antiquity, it has been remarked, attributed to the gods its distinctive national type, those of the Ethiopians, for example, being black. Northern mythology reflects accordingly much purer types of womanhood than the Greek. The Valkyries of the North were not voluptuous women, but stern and hardy amazons who could only be won by heroic deeds-battle-maidens who wedded none but their conquerors. Their power dwelt in their chastity, for once conquered by passion they became simple mortals. Not only was the German wife not bought or treated like a slave, but on the morning after marriage the husband made her a gift -a Morgengab, the origin of the English jointure. ${ }^{1}$ The self-respect engendered among Northern women appears to have been very great. When an army of the Teutons was overcome by Marius their wives

1 Laboulaye's Histoire Civile et Politique des Femmes. 
pleaded that their honour might be respected. They were given to understand that they must submit to the ordinary conditions of slavery, and that night they all perished by their own hands, preferring death to dishonour. By the uncivilised German and Gaulish warriors this honourable sentiment of their womenlind was reciprocated in full. The Romans discovered that the barbarian wives were the safest hostages, for at whatever sacrifice they were always redeemed. When in turn the barbarians overran the Roman Empire they carried their high ideals of morality with them, and thus the seed of the great doctrine of Christianity that a man should have but one wife, and should cleave unto her, fell upon fertile ground.

Whatever may have been or may still be the effects of the destructive criticism directed against the fabric of Christianity as a whole, there is no gainsaying the fact that Christian morality was promulgated at a singularly opportune moment in the world's history. The Jews had not previously distinguished themselves by the purity of their social life. If a divine law was laid down in the Old Testament for the regulation of marriage, it was very liberally interpreted. Polygamy was practised by the patriarchs and sanctioned by Moses. Gideon had seventy sons-the off- 
spring assuredly of a well-stocked harem; David denied himself nothing; Rehoboam had eighteen wives and sixty concubines; Solomon 700 wives and 300 concubines. The same system obtained until the time of Herod the Great, who, according to Josephus, had nine wives. But, alas for the blindness and the misdirected zeal of the early Christians! they wholly misconceived the value of the new faith as an instrument for the reorganisation of society. The potential good that dwelt in Christianity had to assert itself against the whole weight of the authority of the early Church.

There is no more painful spectacle in history than the attitude maintained by the Church towards marriage during the first ten centuries of the Christian era. We can hardly say, indeed, that the Church has ever touched this subject with clean hands, for its tardy adoption of the sacramental view of marriage appears to have been dictated, if possible, by less worthy motives than its previous hostility to the nuptial union. ${ }^{1}$ For many centuries after Christ

1 "The numberless ceremonial impediments that were invented, and occasionally dispensed with by the holy see, not only enriched the coffers of the Church, but gave a great ascendency over princes of all denominations, whose marriages were sanctioned or reprobated, their issue legitimatised or otherwise, and the succession of their thrones established or rendered precarious, according to the humour 
marriage was regarded as a purely civil contract. It was bitterly assailed in that form by the fathers of the Church, and there was a particularly nauseous element in the reforming zeal of these holy men. Chastity was preached not because it was a good thing in itself, but because man's fall and the necessity for his redemption were traced to an indiscretion committed in the Garden of Eden. The polluting influence of passion was not thought to be redeemed by marriage. All intercourse between the sexes was discountenanced. It was taught that to have children under any circumstances was a sin, as it only supplied food for death, and that woman was an instrument of Satan. Continence was declared to be the perfection of virtue. In pursuance of this doctrine, Origen, one of the fathers of the third century, did violence to his own person, and emasculation thereafter was not infrequently practised. Young people were enjoined to enter into vows of celibacy, and multitudes of them did so, nunneries and monasteries being established to receive them. Second or interest of the reigning pontiff; besides a thousand nice and difficult scruples with which the clergy puzzled the understandings and loaded the consciences of the inferior orders of the laity, and which could only be unravelled by these their spiritual guides."Blackstone's Commentaries. 
marriages were denounced as especially abominable. The mystic union of Christ and the Church-which probably would never have been insisted upon but for the fact that the Latin word for church was feminine-was held to be symbolical of marriage, and second marriages were therefore regarded as a sort of infidelity to Heaven. St. Jerome in the fourth century, while treating simple marriage as evil and vicious in itself, reserved the worst vials of his wrath for what was called digamy." This pious father considered that the "clean" animals in Noah's ark were those that had had no intercourse with their kind, the "unclean" being the remainder. Decrees were made forbidding married women to approach the altar or to touch the Eucharist, and it was even declared to be doubtful whether married persons cohabiting with each other could be saved. St. Chrysostom, in the fifth century, boldly averred that if man had not sinned the world would have been peopled by other means. All married persons were exhorted to pray for grace to keep themselves undefiled, and wives were commended for declining the embraces of their husbands.

1 In pagan Rome, and among the Germans also, second marriages were discountenanced, but on the higher ground of the devotion due by a widow to her husband's memory. 
As the result of these doctrines innumerable impediments were thrown in the way of marriage. The forbidden degrees of consanguinity and affinity were extended to a ridiculous length. Widows who had promised to live a single life were excommunicated if they married again. Any married woman who wished to be a nun was allowed to leave her husband and retire into a convent, and he was forbidden to take another wife. All married persons were asked to abstain from cohabitation three days before the Communion and forty days after Easter; next it was held to be as great a sin for a man to coliabit with his wife in Lent as to eat flesh; then marriage was forbidden during Lent and at sundry other specified seasons, until, as an old writer quietly remarks, "there were but few weeks or days in the year in which people could get married at all." As inducements to chastity, stories were circulated as to men who had won a crown of glory through resisting the blandishments of courtesans and other vicious women, and as to virgins who had been miraculously cured of diseases through refusing to uncover to doctors. No ordinance, in short, was too monstrous, no tale too extravagant, to serve the purpose of checking the legitimate intercourse of the sexes. 
Meanwhile the clergy married and unmarried themselves like other members of the community. Until the third century no restriction was placed upon the marriage of priests, but about that time the opinions of the fathers touching celibacy began to make it difficult for priestly unions to be entered into, and in the fourth century such unions, although common, were generally held to be inexpedient. In the fifth century priests were expected at least to abstain from the privileges of marriage, if not from marriage itself. Pope Innocent I. refused holy orders to any one who had married a widow, and commanded every priest to be deposed who should be guilty of the crime of having children by his wife. It was not, however, until the twelfth century that the wives of the clergy were driven forth for good, and that the Roman Catholic priesthood was permanently established upon a celibate basis. During all this time the greatest disorders, both outside and inside the Church, prevailed. Marriage was restrained, but not indulgence. Chassez la nature, says the French proverb, elle revient au galop, and the Church contrived to furnish a striking exemplification of the proverb. Some of the popes led scandalous lives, and the clergy who did abstain from marriage kept concubines, some- 
times in large numbers. A Spanish abbot was discovered in the year 1130 to have seventy concubines, and a bishop of Liège in 1274 was deposed for having sixty-five illegitimate children. Enactments had to be passed forbidding priests to live with their mothers and sisters, because of the prevalence of incest among them; nunneries and monasteries were hotbeds of debauchery; and congregations who had an unmarried priest to minister to them stipulated in some cases, with a view to the protection of their wives and danghters, that he should keep a concubine. ${ }^{1}$ In a similar spirit it was decreed by a council that no priest should be allowed to go out at night without a candle.

Despite the views of the fathers and the various enactments of the Church against marriage, many devout persons never lost faith in an institution which had been pointedly approved by St. Paul, and although marriage was a civil contract with which, for a thousand years at least, the Church, in its collective capacity, would have nothing to do, those exemplary Christians acquired the habit of calling in a priest to bless the nuptial union, which they very properly regarded as an important event in their lives. Ulti-

1 Lea's History of Sacerdotal Celibacy. 
mately this appears to have suggested to the Church the expediency of taking under its control a ceremony which it was powerless to prevent. Down to the eleventh century marriages were made without ecclesiastical interference. But in the twelfth century Peter the Lombard discovered the institution of the seven sacraments, or the sevenfold operation of the Spirit of God in baptism, the Lord's Supper, confirmation, penance, orders, extreme unction, and matrimony; and the Church soon afterwards adopted this view, with results that have profoundly influenced society down to the present time. In Roman Catholic countries there exists a general feeling that marriages contracted without the agency of the Church are not binding; and even in England many worthy people, ignorant of history, confound the divine origin of marriage with the performance of the nuptial rite by a clergyman.

The sacramental view of marriage commended itself to the Council of Trent, which at the same time decreed that adultery did not dissolve the nuptial contract, notwithstanding that divorce for much less weighty reasons had been freely recognised, and indeed encouraged by the Church in the preceding centuries. Since the fourteenth century the attitude of the 
Church of Rome towards marriage has remained unchanged. It is regarded as a ceremony which a priest alone can perform, while its essential uncleanness is asserted by the existence of nunneries and monasteries, to which women and men are invited to betake themselves for the purpose of leading a holy life. Nor did the Reformation essentially modify the ecclesiastical law in England beyond allowing the clergy to marry, and sanctioning marriage at all seasons of the year. After the pope's supremacy was overthrown, the doctrine and discipline of the Church with respect to marriage continued to be pretty much as before. Edward VI contemplated allowing divorce for "adultery, desertion, cruel usage, or perpetual contention." This would have been a very liberal measure, but unhappily its projector died before it was carried into effect, and the English Divorce Act was not passed till the year 1857. Other European countries have, like England, established civil liberty with respect to the marriage contract, but the ecclesiastical spirit remains everywhere opposed to divorce, and inculcates the impurity of an instinct which it identifies with "original sin."

It would seem that in the course of these many centuries the Christian doctrines of purity have prac- 
tically implanted a new instinct in our nature. For the conviction entertained in Christian communities as to passion being an unholy thing is now nothing less than an instinct, and one that has shaped our entire social life. The glimpses already given of pagan and savage customs enable us to judge of the extent of the moral revolution that Christianity has effected. Outside certain schools of philosophy, such notions of purity as now prevail were unknown to the ancients. Nor do they obtain among nations or peoples who have never come under the sway of Christianity. The stigma attached by the Church to all that relates to the reproduction of the species is a fact of which the most enlightened Englishman at the present day is more or less conscious. What other influence, we may ask, could betray a writer like Lecky into declaring it to be "an ultimate fact in human nature that the sexual side of our being is the lower side, and that some degree of shame may appropriately be attached to it"? It would surely be difficult to maintain upon strictly philosophical grounds that an instinct or an appetite upon which the very existence of the human race depends is essentially a degraded one. As well stigmatise eating and sleeping as

1 I.ecky's History of European Morals. 
shameful indulgences, or life itself as a discreditable thing. It is true that some of our most necessary appetites, besides the sexual one, are the subject of a very widespread moral reprobation, eating and sleeping being of the number. Many men boast of their love of art, for example, but few are prepared to boast of their love of beef or mutton. In these sentiments the influence of the Church is again to be traced, asceticism or the mortification of the flesh having been regarded from the earliest times as conducive to holiness.

These various influences have not been uniform in their operation throughout Christendom; they have been strengthened or weakened by the special circumstances of each country. Thus the public sentiment of England, with regard to certain breaches of the moral law, is much more stringent than that of France. Virtuous women are common in English literature, whereas in French they are exceedingly rare. ${ }^{1}$ In French society hardly any stigma attaches

1 Professor St. Marc Girardin, in his Cours de Littérature Dramatique, relates the following curious experience :-

"Quand je faisais à la Sorbonne, il y a ringt ans, la comparaison de l'expression des divers sentiments du cœur humain, j'allais cherchant partout dans le drame et dans le roman modernes. une femme lonnête; je priais même mes amis de s'associer à ma 
to a faux ménage, and although young girls are jealously guarded, married women are tacitly allowed an amount of freedom which in England would entail upon them a loss of consideration. We have already spoken of the evil results of the mariage de convenance in destroying the sanctity of the nuptial tie. It is beyond all doubt responsible for the laxity of French morals, in both a literary and a social sense. If we observe the disfavour with which the public in a theatre watch the efforts of a parent or guardian to marry a girl to some detested suitor, and with what delight they see true love get its way, we need not be surprised at the indulgence shown to the victims of a system of loveless marriage, which in France is sustained mainly by its connexion with the laws of property. The growth of Puritanism in England again has had effects which are felt to this day; whereas in France that movement, with its recherche; ils me répondaient en riant que les femmes honnêtes abondaient dans le monde en dépit de la médisance mais qu'elles étaient rares ou introurables dans la littérature. Je viens de recommencer pour l'amour conjugal la quête que je faisais d'une femme honnête et j'ai cherché si au 17eme siècle, au 18eme ou de nos jours, cet amour, soit dans son dérouement tendre et passionné, soit dans ses félicites innocentes avait été representé quelque part. J'ai à peine trouvé, ça et là, quelques esquisses de ce senti. ment." 
long train of moral and political consequences, was nipped in the bud.

If we turn to Russia, we find women still treated like slaves or cattle among the masses of the population. In novels and dramas of contemporary life in Russia the wife is represented as being in complete subjection to her husband, while among both sexes the loosest ideas of morality prevail. ${ }^{1}$ Russia, although ranking as a civilised country, brings us into touch, in fact, with the customs and instincts of savagery, due to the long existence of serfdom. Until the reign of Peter the Great, Russian women enjoyed no social or domestic authority whatever, and wives could be killed by their husbands with Impunity. ${ }^{2}$ Ireland, on the other hand, presents the exampie of a country where the purity doctrines of the Church have had the fullest sway. That Irish

See the popular dramas of Tolstoi and Ostrowsky.

2 Levesque's Histoire de Russie. Rulhière in his Histoire de l'Anarchie de Pologne relates that in the reign of Catherine the Court amused itself by celebrating "les noces d'un bouffon avec une chèvre." The morality of that Court is also reflected in an anecdote told by the same authority of a grand-duke, one of Catherine's husbands: "Il avait pris l'envoyé du Roi de Prusse dans une singulière faveur. Il voulait que cet envoyé avant son départ eût toutes les jeunes femmes de la cour. Il l'enfermait arec elles et se mettait, l'epée nue, en faction à la porte." 
women are exceptionally virtuous is no vain boast, and it is also an undoubted fact that among young Irishmen are to be found examples of continence unknown elsewhere. This state of things cannot be attributed to the custom of early marriages, which are just as prevalent among the working classes of London as they are in Ireland; it is unquestionably due to the influence of the priests, exerted both by precept and example.

Many specious arguments in explanation of chastity have been put forward by the utilitarians, whose system resolves itself mainly into this, that virtue is a wise and vice an unwise pursuit of pleasure, and that a person is moral or immoral in accordance with the calculation he may make as to where his interests lie. Mill discusses very ingeniously in this sense the case of a man who is tempted to commit adultery with his friend's wife. The obvious motive to the act he may disobey. In that case, says Mill, he obeys other motives that are stronger. "Though pleasures are associated with the immoral act, pains are associated with it likewisethe pains of the injured husband, the pains of the injured wife, the moral indignation of mankind, and the future reproaches of his own mind." Some men 
obey the first rather than the second motive. "In these," says Mill, "the association of the act with pleasure is from habit unduly strong, the association of the act with pains is from habit unduly weak. This," he adds, "is the case of a bad education." 1 Here Mill seems to overlook an important restraining motive, namely, the sense of honour, which under different forms exists in both sexes.

The sense of honour is similar to honesty, and grows up under like conditions. Suppose a man has the opportunity of stealing a five-pound note. He may be very hard up, he may know that the money will never be traced or even missed, and yet he refrains from taking it. Why? Evidently he enters into no selfish calculations with himself, but unreflectingly obeys an innate sense of honesty which springs up and becomes hereditary in a law-abiding people. So with the class of moral offences referred to by Mill. To men guilty of seduction or adultery a certain amount of blame is attached in a society where such acts are recognised to be contrary to the general interest, and the continued reprobation of such offences gives rise in time to an instinctive selfrestraint on the part of men which is not to be

1 Mill's Analysis of the Human Mind. 
confounded with pure selfishness. In the case supposed by Mill self-restraint may be dictated in part by selfish or utilitarian considerations, because men's sense of honour with reference to the indulgence of appetite is not at the best very strong, and may, like other virtues, such as honesty, love of fair play, compassion or benevolence, be wholly absent. But the incompleteness of the utilitarian theory will be seen if we pass from the case of men to that of women. From causes explained in a previous chapter men have exacted from women a much more rigid and uncompromising virtue than women have exacted from men, and the result is that a woman's sense of honour has become perhaps the strongest feeling of her nature. In the highest type of womanhood the sense of honour may certainly be said to have passed altogether out of the range of selfish considerations, and to have become a blind inexorable instinct, which is not to be reasoned with, and which not even the fear of death can overcome.

It is very fallacious in this connexion to set the experience of one age or people against that of another. Cervantes in Don Quixote quotes a popular saying derogatory to female virtue- 
Es de vidrio la mujer

Pero no se ha de probar

Si se puede, o no, quebrar

Porqué todo podria ser-1

and then proceeds to prove it by his story of "El Curioso Impertinente." This may have been an apt illustration of feminine weakness in the Spanish society of the sixteenth century, but it does not follow that it applies uniformly to the English womanhood of to-day. The sense of honour in both sexes is so essentially a thing of cultivation that we have only to consult the social history of a people in order to learn whether that virtue may be looked for in a general or in an exceptional form, or whether it will be entirely non-existent. The morals of a nation are determined by its experience. If among certain peoples of antiquity virginity has been prized, others have set a stigma upon it, the former being governed by a secret sense of the evils of unbridled commerce as affecting their social constitution, and the latter feeling more particularly the necessity of recruiting their population for warlike or other purposes. The licentiousness of England at the Restoration was a reaction against the pernicious straitlacedness of

1 "Woman is of glass, but it is unwise to try whether she will break or not, because anything may happen." 
Puritanism, and it resulted speedily in the establishment of an equilibrium between the two systems which has since been maintained. What we are pleased to call the immorality of the Latin races of the present day, in so far as it exists, is essentially a protest against a noxious system of marriage which it will inevitably modify.

We have traced the influence of Christianity in evolving not only the general European law of monogamy, but the moral sentiments connected with it. Christianity has certainly done much for the elevation of women, and that in opposition, for the most part, to the efforts of the Church. It has effectually abolished open concubinage, established monogamy upon the strictest basis, and released wives from a life of seclusion and bondage. Without it a reaction against the excesses of pagan society could not have been long delayed, but the movement might have taken a different and less beneficial direction. If certain schools of philosophy began a reform, the good work was immensely quickened by the fanaticism of the early Christians. The Church, it is true, has reimposed upon women many of the civil disabilities from which, under the Roman dispensation, they contrived to shake themselves free, but despite 
the worst efforts of bigotry and intolerance for the debasement of men, we can detect in much that Christianity has done the beneficent finger of evolution. In subsequent chapters it will be our duty to show in what manner monogamy operates to the advantage of the species. Meanwhile we have to inquire into the working of certain independent agencies which have co-operated with Christianity in furthering the interests of the female sex, and indirectly those of mankind. 


\section{CHAPTER IV}

\section{CHIVALRY AND PLATONIC LOVE}

That social and religious movements may work for good not only without the concurrence, but even in opposition to the aims and intentions of their promoters, is shown by the growth of the great mediæval institution of chivalry. Chivalry was an offshoot of Christianity, being in the first instance a device by the clergy to utilise for the defence of the Church the turbulent militarism of the feudal system. But if religious in its origin, it soon developed a spirit of its own which was not only foreign to ecclesiasticism, but ultimately became hostile to it. The hardships inflicted upon women by the Church in the shape of a general unsettlement of the domestic relations were mainly instrumental in effecting this change of purpose in chivalry. Not only did the mediæval Church declare that woman was in some sort an unclean thing, or at 
the best a necessary evil, but until the recognition of marriage as a sacrament the flimsiest pretexts for divorce were accepted by the clergy. The husband who desired to get rid of his wife had only to discover some distant degree of consanguinity or affinity between his family and hers, such as exists between almost any two people in a parish. This was suffcient ground for a divorce, and as women in the tenth or eleventh century had to a great extent lost the power of holding property in their own right, which had been the safeguard of the later form of marriage in Rome, much injustice and suffering was entailed upon the sex.

Chivalry first became an instrument for righting the wrongs of individual women; then it developed into a cult of womanhood in the abstract, its fundamental axiom being that a knight should honour and serve all women for the love of one. Theoretically this devotion was exempt from sensuality, and a curious system of metaphysical subtleties and refinements sprang up in consequence. Love was esteemed to be the principle of all virtue, all moral excellence. It had its etiquette, its obligations, its laws. Some of the rules laid down were of the most fantastic description, but their general effect was to invest woman 
with quasi-divine or angelic qualities. The virginity ideal of the Church had no place in the chivalric creed. The cavalier indeed generally selected as the object of his devotion a married woman, and the fact of the lady having already a champion or a dozen champions at her beck and call was no bar to the formation of new ties of the same tender kind. Women who enjoyed a reputation for beauty had knights in their service by the score. On the other hand, plain women, whose need of protection might be greater, were no doubt neglected or overlooked.

It was in the south of France, and chiefly in Provence, that the principles of chivalry found their earliest and fullest development. In other parts of France, and in Germany and England, feudality and chivalry remained legally distinct. The possession of feudal privileges was essential to knighthood in the North; it was only by royal favour that a northern "villain" or commoner could be elevated to knightly rank. But the cavaliers of Provence were recruited from all ranks of society; of 500 whose names have been preserved not more than one-half belonged to the feudal classes, many of them being simple troubadours, extremely poor, and depending for a livelihood upon their poetic faculty or the 
bounty of wealthy patrons. The songs of the troubadours were a characteristic feature of chivalry, and did much to foster the growth of the cult.

As one lady might have many attendant cavaliers, there was a regular ceremonial observed at their initiation, and various degrees of attachment were recognised. The ambitious neophyte who joined a lady's train of admirers might hope to rise through all grades of attachment to the enjoyment of exclusive privileges; but in the case of famous beauties there was necessarily much competition. It was customary for the cavalier at his initiation to kneel before the lady with his hands joined, and in that attitude to swear that he would faithfully protect her to the best of his power from all wrong or outrage until death. Upon this she handed him a ring in token of her acceptance of his service, and as he rose she gave him a kiss, which was often the first and the last he could boast of. Sometimes the bond between the knight and the lady was deemed to be of so important a character that a priest was called in to bless it.

For the settlement of metaphysical difficulties in connexion with the practice of chivalry Cours d'Amour or love-tribunals were established. These 
bodies were composed of ladies, and many of their decisions, as formal as those of a court of law, have been preserved by historians of the time. A famous problem proposed for solution was this: "Can love exist between married people?" It was solved in the negative, and the precedent so established was frequently referred to and acted upon. Indeed, marriage seems to have fared rather badly at the hands of the ladies composing the Cours d'Amour. If a lady married her cavalier she was deemed to have lost him as a lover, and was ordered to take another in his place. ${ }^{1} \quad$ Absurd as these sentiments appear, they had a raison d'etre in the fact that marriage at that period was too often a mere matter of business. In the feudal caste matrimonial connexions were

1 "Un chevalier aimait une dame qui, éprise de son côté d'un autre amour ne pouvait répondre au sien. Ne voulant cependant pas lui ôter toute espérance elle lui avait promis de le prenđre pour chevalier dans le cas où elle viendrait à perdre cet autre chevalier qu'elle aimait. Peu de temps après elle se maria avec ce dernier et alors, celui auquel elle avait fait la promesse, en demanda l'execution. La dame mariée affirma ne rien lui devoir, puisque loin d'avoir perdu le chevalier qu'elle aimait, elle l'avait pris pour mari. Ce fut un débat sur lequel la fameuse Eléonore de Poictiers fut appelée à prononcer. Elle condamna la dame à tenir la parole qu'elle avait donnée par la raison qu'elle avait véritablement perdu son premier amant en le prenant pour mari."-Fauriel's Histoire de la Pocsie Provençale. 
commonly formed for the purpose of furthering the husband's political ambition or adding to his wealth and influence. To those remote days, in fact, may be traced the sentiment so frequently to be met with in French literature that "Le mariage est le tombeau de l'amour."

How the Cours d'Amour enforced their decrees we are not told, but they probably exerted some influence upon public opinion. That the pretty maxims of the cult were carried out to the letter in all cases we can hardly suppose. Passion was understood to be wholly eliminated from the engagements entered into on one side and the other, so much so that wives made no concealment to their husbands of the fact of their having a cavalier." "Il ne sait d'amour vraiment rien," says a troubadour, "celui qui désire la possession tout entière de sa dame." The wives were equally complaisant towards their husbands, who acted as the cavaliers of other ladies.

Flourishing as they did for a hundred years, chivalry and troubadourism were something more

1 "Seigneur" (says the beautiful Oriunde to her husband in one of the romances of the period), "mêlez-vous de votre guerre et laissezmoi faire l'amour. Vous n'y avez nul déshonneur, puisque j'aime un si noble baron et si expert aux armes, que Roland, et que je l'aime de chaste amour."-Fauriel's Poesie Provençale. 
than a sentimental craze. The early Church did its best to throw women back into a state of serfdom, and succeeded only too well. It was in the Middle Ages and under clerical influence that they were loaded with the civil disabilities from which they still suffer in most Christian countries with respect to property; and chivalry, while professing sentimental aims, was in reality the first protest raised against this retrogressive policy. It was the beginning of the movement which within recent years has resulted in this country in the passing of the Married Women's Property Act-a measure conferring upon the Christian woman for the first time a right enjoyed by her pagan sister in Imperial Rome.

Whether chivalry was imported into Germany and England, or whether it arose spontaneously in those countries, is a debatable point. The evidence rather points to its indigenous growth. The German Minnesingers, the troubadours of the North, flourished a century later than those of Provence, but, on the other hand, the Niebelungenlied, although dating from the thirteenth century, was compiled by an anonymous Minnesinger from folklore of much earlier date. The Edda, or book of Scandinavian mythology, which vaunts prowess and love, and after a fashion inculcates 
respect for women, belongs to the seventh or eighth century. Then the English legends of the Round Table, although compiled by Geoffrey of Monmouth in the twelfth century, are traceable to an earlier period. As a social force, however, German and English chivalry, the keynote of which was rude heroism rather than gallantry and refinoment, may be dismissed from our present study. It was the chivalry of Provence that produced a lasting effect upon the relations of the sexes, and it did so mainly by inspiring the poetry of Dante and Petrarch, and thereby giving birth to a new and powerful factor in literature and art widely but erroneously called Platonic Love.

Among men the mention of platonic love commonly provokes a smile. The term has unfortunate associations, being often used as a cloak for flirtation of a more or less dangerous character. But platonic love has played no unimportant part in the shaping of modern ideas, and it may be well therefore to trace briefly its origin and development. The ancient Greeks idolised beauty of form. They beautified all they touched. The grotesque divinities of Egypt and Babylon lost their ugliness when transported to Mount Olympus; and what the sculptor did for those monstrosities, that 
did Plato for the passions of men-he refined and embellished them. The germ of the so-called platonic love is to be found in Plato's treatise of The Banquet, a series of dissertations upon love, supposed to be delivered by Socrates, Aristophanes, and other distinguished guests at the dinner-table. Here the contemplation of beauty of form leads to the contemplation of beauty of ideas; finally the mind is invited to pass to the pure conception of the beautiful, that is to say, to beauty divested of all perishable attributes, such as age, country, or sex,-beauty as an ideal, possessing neither form nor substance, and knowing neither growth nor decay. This sort of beauty is of course a mere abstract principle, and were platonic love concerned with nothing more practical than that, it would never have found a place in modern sociology. Plato's idea was discussed by other philosophers, but it never entered into Greek poetry or drama, and never influenced the course of Greek life. It needed a different soil from that of Greece in order to bear fruit; and the true sphere of its action proved to be Christianity and chivalry. The Christian fathers were admirers of the platonic philosophy, in which they discerned many of the elements of Christianity, this very conception of the 
beautiful being supposed to have some affinity to the godhead of the Church.

Chivalry was platonism applied to the conditions of medirval life. Plato took passion as one of the degrees in his ascending scale of the love of the bealltiful. He started with woman in order to conduct us to an abstract idea. Chivalry accompanied him half-way; it rose to the conception of womanhood as an object of veneration, and there stopped. By and by chivalry, as an institution, fell to pieces, but its spirit survived in the poetry of Dante and Petrarch, and is traceable throughout the fabric of modern society. When those writers were born the last strains of the troubadours were dying away, but they took up the burden of the troubadour poesy, each in his own key, and gave expression to what was really vital and enduring in the system of chivalry as distinguished from its metaphysical nonsense.

Platonic love as now understood dates from the raptures of Dante and Petrarch over the ideal Beatrix and the still more ideal Laura. Both poets take a woman as their text, and both lose themselves in adoration of what Goethe calls das ewig Weibliche. The power of beauty and the ideas of happiness and virtue associated with it in noble minds are the 
sources of their inspiration. What they glorify is not so much a woman as an idea. For, to tell the truth, the loves of Dante and Petrarch in their material aspect partake much more of the ridiculous than the sublime. Dante saw Beatrix as a child, and fell in love with her as a model of grace, beauty, and purity; but she never became his wife, his mistress, or even his friend. So far from reciprocating his sentiments, she hardly noticed the love-sick youth who dogged her steps in the streets of Florence. And by great good fortune she died young, remaining a beautiful memory to the poet, who thus never lost his illusions. In recounting the story of his love in the Vita Nuova Dante expresses the fervent hope that he may witness the glory of Beatrix in heaven among the blessed. Petrarch was less fortunate in his attachment. Laura did not die young. In fact, she lived to be another man's wife and the mother of a family. Thus the love of Petrarch for Laura is more literary than that of Dante for Beatrix; it springs more from his imagination than from his heart, ànd it is without regret that we find him in his dialogues De Contemptu Mundi owning to his interlocutor, the spirit of St. Augustine, that his lifelong passion has been a mistake. As exponents of unsensual love, 
however, both Petrarch and Dante strike a note which reverberates through all modern literature. ${ }^{1}$

It would be tedious to trace the platonic idea through its various phases down to the present time, but its results may be noted, and some of them are sufficiently curious. Modern forms of politeness as practised by men towards women have no other origin. The man who hastens to pick up a fan that a lady has dropped by his side, or who, being inside an omnibus, gets outside at some personal inconvenience to "oblige a lady," obeys unconsciously the

${ }^{1}$ Dante talks of Beatrix as he would of a divinity. "Ncar her," he says, "I forgot the existence of my enemies. My whole being seemed suffused with charity and all virtuous feelings. I would have forgiven any one who had offended me; there was no thouglit in my mind but love." In another passage of the Vita Nuova he congratulates himself upon the fact that nobody suspects the object of his adoration. This same feeling occurs in the beautiful lines of Alfred de Musset-

\section{Si vous croyez que je vais dire \\ Qui j'ose aimer! \\ Je ne saurais pour nn empire \\ Vous la nommer.}

Petrarch says of his love: "It is as pure as the beauty of Laura. It is to Laura I owe everything I am. It is her love that has caused the germs of goodness in my heart to blossom; it is she who has preserved my youth from the stains of vice, who has taught me virtue, who has given me the impulse to soar heavenwards. For love transforms a lover's nature, and makes him resemble the object of his love." 
dictates of medirval platonism. Such deference to womanhood is a characteristic of modern Europe alone; it is not to be found in any other age or among any other people. In a scientific sense this emancipation of the weaker sex from a state of real or comparative bondage can hardly be overrated, seeing that it has been the means of ensuring to woman a freedom of action, a power of initiative, the exercise of a right of selection, denied to her in a great measure during the long infancy of the human race. While the comfortable doctrine prevailed, as it did during the Hindu, Egyptian, Greek, and Roman civilisations, that the father alone determined the character of the child, the wife's preferences in the matter of a husband were counted as naught, and systematically repressed. That is still the rule in polygamous countries at the present day; and its results are seen in the backward condition of three-fourths of the human race. 


\section{CHAPTER V}

\section{THE LAW OF HEREDITY}

IT is a matter of common observation that children resemble their parents. They do so in varying degrees. Some members of a family are like their mother, others their father; very often the characteristics of both parents are combined in the offspring. Physically, these resemblances have always been undeniable, but, strange to say, it has been reserved for modern science to establish beyond a doubt the existence of heredity in the moral faculties. All the great schools of philosophy have treated the moral element in man's nature, that is to say, his disposition, his proneness to evil or to good, either as a fixed principle implanted in him without reference to his parentage, or as a thing to be monlded in the individual by his will and his surroundings. Both these hypotheses, we now know, were partly right and 
partly wrong. Hence the endless controversies maintained by the adherents of the Intuitive and the Utilitarian systems of philosophy, each party being able to support its views, to some extent, by unimpeachable arguments. The truth is that within certain limits utilitarian considerations sway the individual, and that these establish a bent in his nature which, becoming ingrained, is transmissible to his posterity. It was this hereditary tendency which constituted the Greek Nomos or custom having the force of law, as described by Grote-the established fact and condition of things which each new member of the community is born to and finds subsisting, the aggregate of beliefs and predispositions to believe, ethical, religious, æsthetical, social, respecting what is true or false, holy or unholy, honourable or base, in all the relations of life. ${ }^{1}$

Recently physiologists have begun to doubt whether the influence of circumstances upon the species is as immediate as Darwin assumed it to be, Weismann's much-discussed theory of heredity (Die Continuitait des Keimplasmas) appearing to exclude the transmission of acquired or accidental modifications of structure, and to greatly circumscribe the Darwinian theory

1 Grote, Plato and the Companions of Socratcs. 
that instinct is inherited custom. It is certain, however, that, by whatever means produced, congenital peculiarities of the moral character exist and are transmissible side by side with the physical.

The importance of this principle need not be insisted upon. Obviously many cherished beliefs, religious and philosophical, have to be sacrificed in view of the fact that men are born with their moral natures as deformed or as imperfect as their physical ones. Children may truly enough suffer for the faults of their fathers even to the third and fourth generation. We can no longer believe that there is such a thing as absolute free will, or that education has any but a relatively small part in the shaping of individual character. I Within certain limits the thief steals, as the duckling swims, by instinct; the murderer resorts to violence as naturally as a cat hunts a mouse. On the other hand, the good man acts to a great extent upon the impulses transmitted to him by his parents; virtue is inherited like land or money. And what of the mysterious "I" of our natures, it may be asked, the ego, the moi pensant? Modern biologists show it small mercy. Ribot in his

1 The famous Letters of Lord Chesterfield were written to mould the character of a natural son, who, however, turned out quito otherwise than his father intended. 
recent work on heredity observes that the intelligence, sentiments, instincts, and the organism generally, being all transmissible, the individual " $I$ " is obviously a resulting quantity and not a mysterious and separate creation. ${ }^{1}$

The last serious opponent of the law of moral heredity was Buckle, the historian of civilisation, whose philosophy has been proved to be more ingenious than sound. Buckle contended that proof of hereditary talent, hereditary vice, or hereditary virtue, could only be furnished by an untrustworthy method of induction. To point to the existence of certain qualities in a father and a son, and to argue that there was a necessary connexion between them, was a mode of reasoning, he declared, by which it would be possible to demonstrate any proposition whatever. No doubt! But if the particular qualities of a man reappear in his son with greater certainty and regularity than they do in the son of his friend, the presumption

1 "Si l'intelligence, les sentiments, les instincts, l'organisme, suffisent à expliquer la personalité, nous r'avons aucune raison d'admettre que l'hérédité est limitée par quoi que ce soit. Sans doute les earactères nous offrent une diversité infinie, mais les elements intellectuels, affectifs, vitaux, peuvent s'associer, de tant do manières, dans des proportions si variées, que les differences s'expliquent tout aussi bien par eux, que par l'hypothèse d'une entité mysterieuse et transcendante."-Ribot, L' Hérédité Psychologique. 
in favour of heredity is proportionately strong. While Buckle was enunciating his fallacy a French savant, Prosper Lucas, was collecting and collating an immense body of facts bearing upon and proving the truth of heredity, and his work, ${ }^{1}$ although published forty years ago, remains a text-book of this branch of science.

Hereditary resemblances extend far beyond the limits of a family circle. There is no difficulty in telling a Jew by his nose, which is as much a matter of heredity as the thick lip of the Imperial house of Austria. It was remarked a few years ago that the sister of one of our English dukes bore a strong resemblance to her ancestress Nell Gwynne, and there are few families possessing portraits of their members for a number of generations who could not point to similar examples of heredity. Not only is every organ and mental faculty transmissible, but the various successive phases of the parent's life, physical or mental, may be repeated in the child. "In the absence of any disturbing agency the son attains maturity, becomes gray or bald, acquires a stoop or a round belly, loses his teeth and memory, and finally

${ }^{1}$ Lucas's Traité Philosophique et Physiologique de l'Hérédite Naturelle. 
yields up his life at about the same age and after the same manner as his father." ${ }^{1}$ It is well known that life assurance companies take note of hereditary tendencies to disease or early death.

Among the different nations of Europe we can distinguish certain particular types. It is easy to tell an Italian from a Scandinavian or a Spaniard from a German. As we cannot suppose that there have been separate creations of Italians, Scandinavians, Spaniards, and Germans, we must look to local causes for an explanation of this fact. Ethnologists feel obliged to assign these divergences of race to food, climate, and other physical conditions. They are right, no doubt. At the same time, if a Spaniard and his wife migrated to Germany and there had a son, the latter, although living under German conditions, would indubitably grow up a little Spaniard, with not only the looks but also the temperament of the Spanish race. This would be a triumph of heredity over physical surroundings. If, on the other hand, a Spanish colony settled in Germany and remained there, we are bound to believe they would eventually conform to the German type; the influence of physical surroundings, steadily exerted, would gradu-

1 Sir Thomas Watson's Lectures at King's College. 
ally overcome that of heredity, although the process might occupy thousands of years. Thus we see that heredity and physical conditions work together in the moulding of a race. In each successive generation a certain amount of the physical influences to which the individual has been subjected is transmitted by him, and thus, the conditions remaining unchanged, the hereditary tendencies of a family or a people accumulate. Among the influences to be reckoned with, in this connexion, are similar habits of thought. A man and his wife often get to look alike in old age, and even men of the same trade or profession may acquire a general resemblance to each other. Is there not something characteristic in the family doctor and the money-lender, for example?

The case of the Jews is interesting from the heredity point of view. They are to be found in every country in Europe, and although they strictly intermarry, they are not everywhere identical in physique. The Portuguese or Spanish Jew differs from the German Jew. Notwithstanding that each may be of pure extraction, he conforms more or less to the type of the people around him. This is the result of the climatic and other physical conditions. It is mainly the hair and the complexion that are 
thus affected, for the shape and the expression of the features (depending perhaps upon moral causes) are everywhere significant of Jewish blood. Morally, the Jews of every country are subject to certain influences in common, and possess therefore a common character. Having no fatherland, they liave, as a rule, no faculty for self-government, no capacity for political life or military organisation, no patriotism, no concern with the questions of aristocracy, democracy, and feudality, upon which the history of the Indo-European peoples has turned. In place of courage, they have shrewdness; they devote themselves to trade and finance, and with the sentiment of race exclusiveness strong within them, they have developed a special code of morality in dealing with their Gentile neighbours. On the other hand, they excel in some of the pleasing arts, such as music and the lighter forms of literature.

The saying of Victor Cherbuliez that "every country has the Jews it deserves," is true only in part. Jews who have lived for several generatious under au enlightened government are not prone to underhand and treacherous practices like other sections of the race who upon religious grounds have long been oppressed; the English or French Jew is on the whole, therefore, a better citizen than the Jew 
of Eastern Europe. But religion and race sentiment will always make the Jew a different man from his Christian neighbour. Moreover, the migrating Jew brings with him to a free country like England the habits of mind appropriate to the less civilised community he may have left, and such moral peculiarities cannot be corrected in a single generation. Breeders of domestic animals know that it takes six or eight generations to fix or unfix a given quality by heredity, and men are hardly to be judged by a less exacting standard than horses or dogs. For these various reasons Macaulay's tirade in favour of the admission of Jews to all the privileges of English citizenship, not upon the ground of political expediency, but because of their inherent identity with Englishmen in civil instinct, may be set down as a piece of empty though brilliant rhetoric. ${ }^{1}$ Macaulay argued that it would be as reasonable to place all red-haired men under a political ban as Jews. If it could be shown that all the red-haired men of Europe were of one race, that they had had no fatherland for two thousand years, and that during most of that time they had been shamefully oppressed by their fair- or black-haired neighbours, the argument would hold

${ }^{1}$ Macaulay's Essay, "On the Civil Disabilities of the Jews." 
good, but not otherwise. Now that the civil disabilities of the Jews have been abolished in this country, we may assume that the English branch of the race will conform to English standards of morality more completely than they have hitherto done; the fallacy enunciated by Macaulay is none the less instructive.

Another example of the force of hereditary influence is furnished by the gipsies. Under a variety of names the Romany race are to be found all over Europe, and their practice of intermarriage has preserved their characteristics. Nomadic and acknowledging no civil authority, they have little or no sense of the sacredness of property. They thieve by instinct. From highly-policed countries like England and France they have almost disappeared, but they still flourish in Spain and the east of Europe. All attempts to get them to settle down to civilised life have proved fruitless. ${ }^{1}$ The Austrian Government once tried to form a regiment of gipsies, but they ran away at the first encounter. Gipsy children who have been put to school take to vagabondage at the age of twelve or fourteen.

National character, like animal instincts, persists through an endless number of generations. The 1 Rochas, Les Parias de France et d'Espagne, Bohemiens et Caguts. 
Gauls, described by Cæsar, appear to have had much in common with the French people of the present day; they were fond of revolutions, impulsive, easily led by false reports, ready to declare war without reason, and quickly discouraged in defeat. Ethnologists rely upon heredity in tracing out even the constituent elements of a nation. Without hesitation they can pronounce the population of one English county to be largely Danish, for example, or that of another Celtic, and so on, and the characteristics of the different races must have been maintained in such cases for over a thousand years. ${ }^{1}$

Leaving nations and coming to individuals, we discover curious irregularities in hereditary transmission. Physical or moral characteristics-using the word moral in its widest sense-sometimes skip a generation, passing from a man to his grandson; daughters may be like their fathers and sons like their mothers, or vice versa; and moral resemblance may accompany physical resemblance or it may not. Heredity thus appears to act capriciously in individual cases; but like the law of averages, its results, when observed over a sufficiently wide area, are pretty uniform. Darwin surmises that the germ of

1 Beddoe, The Races of Britain. 
a defect or a quality may be transmitted from generation to generation in a latent form, and suddenly revive under favourable conditions. Weismann now declares the transmission of germ-plasm, intact, from one generation to another to be a fact, his contention being that in each individual a portion of the specific substance derived from the parents is not used up in the construction of the body of that individual, but is reserved unchanged for the formation of the germcells of the succeeding generation. This theory seems to explain the curious principle of throwing back, and it tends at the same time to eliminate from the professional breeder's calculations the so-called principle of inneite. The horse or the dog that has been pure-bred for a sufficient number of generations may be counted upon to exhibit no reversion to inferior blood. But a flaw in the animal's pedigree within six or eight generations is always a source of danger. It may crop up at any time; in other words, the animal, although nominally pure, may throw back to some defective ancestor.

There is every reason to believe that human beings are subject to the same principle of reversion as the lower animals; but it is obvious that many generations must be closely studied before the law can be 
thoroughly understood. At present the materials for a comprehensive judgment upon the subject are lacking. Few of us know anything of the real character of our grandfathers or grandmothers, and remoter ancestors are quite beyond our ken. Even in the case of illustrious men, the facts that would be most useful to the student of heredity have not been observed or recorded. From this point of view very little existing biography is of any value. If anything is told us of a great man's father, his mother is often ignored altogether, and in any case the facts related are usually meagre. It is certain that many of our instincts are very deeply rooted. In menageries straw that has served as litter in the lion's or the tiger's cage is useless for horses ; the smell of it terrifies them, although countless equine generations must have passed since their ancestors had any cause to fear attack from feline foes. ${ }^{1}$

By the seemingly capricious action of the germplasm a curious element of uncertainty is introduced into heredity. This is the tendency of characteristics to become metamorphosed in passing from parent to child. Nervous affections are especially subject to this transformation. Convulsions in the parent may

1 Laycock's Orgunic Laws of Personal and Ancestral Mcmory. 
turn to insanity in the child; insanity may change into a tendency to suicide, and the suicidal tendency may become a mania for drinking. Given some brain or nerve defect in a family, its ramifications may be very widespread. Insanity in one member may be accompanied in another by paralysis, scrofula, rickets, or other irregularities. The present writer is acquainted with a man who, having softening of the brain, has a daughter addicted to drunkenness, who in turn has a child with a club foot. Baillarger insists upon the danger of insanity in all cases where one's blood-relatives (father, mother, grandfather, grandmother, aunts, brothers or sisters) have been affected with weakness of mind, oddity of character, great excitability, nervous affections, suicidal tendency, or drunkenness.

Möbius, Charcot, Féré, and other authorities of the present day, link together an extensive group of brain and nerve diseases, comprising insanity, with its milder forms of eccentricity and violent temper, paralysis, epilepsy, hysteria, neuralgia, scrofula, gout, diabetes, deformities and malformations, consumption, asthma, and dipsomania. All these affections may be found alternating with each other in a given family, one member suffering from one and another from another. 
In their various forms they are believed to be manifestations of a single evil, namely, the imperfect nutrition of the brain or nervous system. ${ }^{1}$ The earliest form of that evil is probably the depression or nervous relaxation produced by the worries of civilised life. It may first manifest itself in the simple guise of indigestion, sleeplessness, irritability, headaches, or general "lowness." By dint of double heredity, that is to say, by its occurrence in both husband and wife, the evil is aggravated in the second generation, and so on, the members of the affected family being finally either rendered unfit to live, or cured of their malady by a sufficient admixture of healthy blood. Upon how minute a scale Nature works Darwin shows in his description of the life-germ which is transmitted in generation. This life-germ is quite invisible to the naked eye. Yet, "we must believe," says Darwin, "that it is crowded with characters proper to both sexes, to both the right and the left side of the body, and to a long line of male and female ancestors separated by hundreds or even thousands of generations from the present time," and that "these characters, like those written on paper in invisible

1 Dejerine, L'Hérédité dans les Maladies du Système Nerveux, Paris, 1886. 
ink, lie ready to be evolved whenever the organism is disturbed by certain known or unknown conditions."

How little the law of heredity is regarded in the daily life of the community we all know; how important to the general welfare is a knowledge of its principles the foregoing considerations abundantly prove. Physical beauty is nearly always allowed to outweigh moral beauty. It is true that physical beauty is very often accompanied by goodness, but the rule has many exceptions which men and women habitually ignore. A man will decline to marry a hunchback, but he seldom or never hesitates to select as the mother of his children a pretty woman because her father is a confirmed drunkard, or because she has an aunt in a lunatic asylum. And having done this, he is surprised to find that his son in due time turns out to be a blackguard, or that his daughter, despite the most careful training, takes to the streets. Recently an ingenious writer, describ-

1 Darwin, Variation of Animals and Plants under Domestication. It is curious to compare this passage with one in Montaigue: "Quel monstre est-ce que cette goutte de semence de quoy nous sommes produits, qui jorte en soy les impressions non de la forme corporelle seulement mais des pensements et incliuations de nos pères!" 
ing a supposed journey to other planets, asked us to imagine a race of beings presenting two visible forms-a corporeal and a spiritual-as inseparable as the Siamese twins. To the student of heredity men and women wear something of this aspect. They walk double; their moral natures are distinct from their physical. Very often their component parts may correspond, but in not a few cases also they are dissimilar, a fine physical nature being accompanied by a dwarfish or deformed moral nature, and vice versd. Could we all see each other in this double character, how different would be our judgment of our friends and acquaintances! The man standing high in office or in the world's esteem might appear a moral pigmy, while another, obscure and unconsider d, might be conspicuous as a moral athlete. Just as the faculties of the body may be cultivated, so unquestionably may those of the mind. Therein lies the value of education, example, and all the other influences that are recognised as beneficial to youth. But the capacity for moral improvement is limited by heredity to a degree little suspected as yet by the majority of mankind, and undreamt of by great thinkers of the past like Bentham, Locke, or Hume. 


\section{CHAPTER VI}

TRANSMISSION OF PHYSICAL AND MENTAL CHARACTERISTICS

Physical heredity extends far beyond those family likenesses so apparent in feature, stature, strength, colour of the hair and eyes, complexion, and so forth. There is not a fibre or a nerve of our bodies, however small or insignificant, or a faculty depeudent thereon, which is not transmissible. The size and shape of the head, bones and teeth, the circulatory system, the muscles and nerves, the digestive apparatus, the richness or poverty of the blood, diseases of the "constituticnal" order, a tendency to early baldness or gray hair, longevity and shortness of life, long and short sight, and malformations, are all matters with which heredity is concerned. Probably all these characteristics are subject not only to direct transmission, but to trans- 
mission in a latent form, although the fact may be apt to escape notice. Such complaints as deafness and dumbness may certainly skip a generation or two. Of this there is an example in the records of the lunacy commissioners of Scotland. A deaf mute man married a woman of normal faculties, and by her had two children, namely, a deaf mute son, who died childless, and an apparently sound daughter, who married a sound man. This woman had two danghters and a son. In the daughters their grandfather's infirnity reappeared. The son escaped it, and married a sound woman. But his son was a deaf mute, inheriting thus the infirmity of a great-grandfather.

Transnitted disease is perhaps more liable to break out in the children who most resemble the affected parent, but this is not a universal rule. Sir Thomas Watson says in his King's College Lectures: "I am acquainted with a gentleman who has lost several brothers and sisters by phthisis. The fatal disposition is known to exist on his mother's side, while his father's is believed to be quite free from it. All the children who have hitherto become consumptive have resembled the mother in bodily configuration and features, except this gentleman, who is like his father's family, but who nevertheless labours 
Imder unequivocal consumption." Haller, the Swiss physiologist, gives an account of a web-footed family descended from a mother in whom that configuration existed. The American calculating boy, Zerah Colburn, belonged to a six-fingered and six-toed family, the peculiarity having in this case been transmitted through at least four generations. Sir Thomas Watson cites two cases of the kind occurring in his own practice-one that of a musical composer, who, like his father, grandfather, and great-grandfather, was web-footed; the other that of a gentleman who, having six fingers, was constrained to admit the paternity, otherwise doubtful, of an illegitimate child similarly deformed. It is impossible to treat such cases as coincidences. Suppose the proportion of web-footed men in London were as high as 1 in 20,000! Against the recurrence of the malformation in the same family, the arithmetical chances would be-for a grandson 20,000 times 20,000 , or $400,000,000$ to 1 , and for a great-grandson 8,000,000,000 to 1 . In point of fact web-footedness shows a marked tendency to run in the blood.

Peculiarities affecting one or two members of a family, and not traceable to either father or mother, have probably come down from some ancestor in a 
iatent form. This must have been so in the case of tie twins mentioned by Darwin, who, unlike their parents, had both their little fingers crooked and a tooth in the upper jaw misplaced. The "latent germ" indeed is one of the most important features of heredity. It is known that a game-cock may transmit his courage through his female to his male offspring, while diseases such as hydrocele, necessarily confined to the male sex, may be transmitted by a man through his daughter to his grandson. Farmers, it may also be noted, take care to employ for breeding purposes a bull descended from a good milling cow. Lucas quotes cases of hereditary fecundity in families existing sometimes on the mother's, sometimes on the father's side, and proves the existence of a similar law in regard to longevity and short life. There are persons extremely sensitive to contact with silk, cork, the skin of peaches, and other objects. This peculiarity is not the result of caprice or fancy; it is hereditary. So also is sensitiveness to tickling, which in some persons may produce syncope. Short sight, when caused by overwork, is said to pass from parent to child. It is alleged that an eye affection, from which watchmakers and engravers suffer, repeats itself in their children, notwithstanding that these may be brought 
up to a different trade. Colour-blindness is well known to be hereditary, and to continue through as many as five generations. Similarly, keenness of vision exists among savage tribes to an extent unknown among Europeans, as the result, no doubt, of cultivation and transmission. Smell and taste are also hereditary senses.

Innumerable illustrations of physical heredity may be found in the works of specialists. Suffice it to say that the transmission of all congenital characteristics, in health or disease, is now an established fact. It is doubted whether accidental peculiarities tend to be transmissible, and Weismann has raised this question in a very crucial form. Circumcision has certainly not been "fixed" among the Jews, nor are smallpox marks hereditary. On the other hand, there are recorded cases of cats and dogs whose tails have been cut off having offspring with short or deformed tails, though the evidence on this point is not conclusive.

More remarkable than the heredity of the individual functions of the body is the alleged transmission of manual dexterity in handicrafts, of what is called an ear for music, of voice and of personal habits depending not upon one organ of the body, 
but upon many combined. The skill of the workers in jet at Whitby is said to be hereditary; Bach was the head of a great musical family, whose talent was probably not all acquired; there have been many families of painters who must have had some hereditary disposition to art. Brothers or a father and son may have voices exactly alike. In Parliament a few years ago there were two brothers who by their voices might have been mistaken for each other; the same may be said of two actors, brothers, well known at the present time on the English stage; and of a father and son who are distinguished journalists in London. By the Countess Walewska Napoleon I. had an illegitimate son who had exactly his father's voice. ${ }^{1}$ Girou de Buzareingues records the case of a man who in bed was accustomed to lie upon his back, and to cross his right leg over his left, and whose infant daughter constantly took the same position in the cradle, despite the resistance of the swaddling clothes. Heredity is also said to affect handwriting.

Naturally the battle of heredity has had mainly to

1 The Duchesse d'Abrantès remarked on this subject: “J'ai retrouvé la voix de Napoléon, de manière à me faire tressaillir toutes les fois qu'elle parvient a mon oreille : c'est dans le comte Walewska. Cette ressemblance d'origine est quelquefois d'une telle force qu'elle fait mal."-Livi, Napoleone all' Isola d'Elba. 
be fought out in the field of moral characteristics. There it has encountered, and still encounters, more prejudice than any scientific doctrine enunciated since the time of Galileo; and there is certainly no question as to its subversive effect upon many of our social institutions. The line of demarcation between physical and moral characteristics is one extremely difficult to draw. In what category are we to place suicidal and homicidal tendencies, drunkenness and sensuality, for example? The truth is, that although we adopt a classification of physical and moral attributes in speaking or thinking of this subject, nature recognises none, the operations of the body and mind being intimately, nay indissolubly, bound up with each other. If physiologists have not yet succeeded in assigning all mental functions to a definite set of physical causes, they have gone far towards doing so, and our knowledge of the subject, thanks to the labours of specialists in England, France, Germany, and Italy, may be said to be daily widening.

At the head of mental characteristics, whose hereditary nature is apparent, we may place idiocy and insanity. The idiot is born with an undeveloped brain, and he transmits his imperfections either drectly or indirectly. Whether in the case of mind 
or body, maladies are liable to skip one or more generations. Haller noticed the recurrence of idiocy in a noble family in the fourth or fifth generation after its first appearance. It is also apt to appear collaterally, an uncle or an aunt of a particular patient being frequently affected. This would seem to show that the germ of the malady existed in a previous generation, although its presence may not have been suspected. It is highly improbable indeed that an idiot should be born of perfectly sound parents. Of the heredity of idiocy medical literature furnishes abundant proof. Insanity, which is a derangement of the functions of a brain more or less perfect in appearance, is similar in its manifestations, except that the patient may have lucid intervals, or even appear to be cured. It may follow the direct line of descent, or may appear collaterally. The fact that insanity, unlike idiocy, may exist without any perceptible deterioration of the brain tissue has led some to doubt whether it was invariably connected with physical causes, but the argument that no physical cause exists because none happens to be visible does not hold water. Our knowledge of matter is bounded by the powers of the microscope. Every increase made in our magnifying apparatus reveals the exist- 
ence of new phenomena in nature, and we have reason to believe that many of the so-called lower animals possess powers of perception, in sight, hearing, and smell, far in excess of our own, with all the assistance that science gives us. If the causes of insanity are not always to be detected by the eye, the hereditary character of the malady is incontestable. As Ribot remarks, every work on insanity is a plea for heredity. Insanity may be bred by worry, though whether a perfectly sound brain ever becomes wholly disorganised from that cause is a moot point. More likely the disease is gradually developed in one or two generations before it declares itself. Once developed, its heredity is unquestionable. As to the proportion of hereditary cases of insanity, Maudsley says "the most careful researches agree to fix it as certainly not lower than one-fourth, probably as high as one-half, possibly as high as three-fourths." 1 The variety of the statistics given by various writers arises from a difference in their methods of observation, some excluding and others including cases of indirect transmission.

Insanity takes many forms. One of the most frequent is a tendency to suicide, the hereditary nature

1 Maudsley's Pathology of Mind. 
of which was long ago remarked by Voltaire. The verdict of "temporary insanity," so often returned by coroners' juries, is generally looked upon as a euphemism for self-murder or felo de se, but there is reason to believe that in many cases it is strictly correct, even where the suicide has carried out his purpose with the utmost deliberation. Voltaire notes the case of a man of a serious profession, of mature age, regular in his conduct, sober in his passions, and well-to-do, who committed suicide, leaving a written declaration to the effect that his death was voluntary. "Strange to say" - we now quote from the Dictionnaire Philosophique - "it was found that his brother and his father had killed themselves at the same age as he." The writer would not have been astonished had he known as much of suicide as a modern mad doctor. Since Voltaire's time hundreds of such cases have been placed upon record. In fact, they are one of the commonplaces of medical science. Not only a tendency to suicide, but a recurrence of the act in families at a particular age, and even in a particular manner, is frequently noted. ${ }^{1}$ Hallucinations follow the same

1 One recorded case will serve as an example of many. "Un monomaniaque se donne la mort à trente ans. Son fils arrive à peine a trente ans qu'il est atteint de monomanie et fait deux tentatives 
course. Cases are known of father and son both given to seeing phantoms; and in the Middle Ages "possession by devils," which was no doubt a form of hallucination, was said to run in families. One of the commonest experiences of the mad doctor of the present day is to find people possessed by an idea that somebody is going to kill or poison them; and a large proportion of such cases are hereditary-according to Esquirol, nearly one-third. In a still greater degree are the violent forms of mania hereditary, the proportion as given by the writer just quoted being nearly one-half. The royal families of Europe, who are extensively allied by marriage, have unfortunately contracted the taint of insanity, and a large proportion of cases have occurred among them since that of our own George III. And what is true of insanity in the main is of course true of all the minor morbid affections to which the brain or the nervous system is liable.

Let us now see what part heredity plays in the sentiments and passions, and in the mental capacity generally. The Borgias, the Stuarts, the family of Charles-Quint, the houses of Condé and Guise, to rede suicide. Un autre à la fleur de l'âge est pris de melancholie et se noie volontairement; son fils d'uue bonne santé, riche, père de deux enfants bien doués, se noie volontairement au même âge."Moreau's Psychologie Morbide. 
call well-known instances in history, bore each a distinctive character. It would be easy to compile examples of heredity from the pages of historians alone. "The whole line of the Guises," says Voltaire, "was marked by boldness, insolent pride, and at the same time by a seductive politeness." Of the Condés Saint-Simon remarks that side by side with courage and military aptitude they possessed the most odious vices-malignity, baseness, avarice, and insolence. Such generalisations, however, are open to the objection that they are of little scientific value. It is more to the purpose to note, as Buffon does, that a kicking horse produces foals of the same character.

Whether among the lower animals or in man, the transmission of moral characteristics is a fact that meets the inquirer at every turn. Lucas and other writers cite cases to prove the existence of a tendency not only to crime, but to particular classes of crime. The individual who inherits a disposition to crimes of violence may be inoffensive with regard to crimes against property. The criminal's usual plea that "something drove him to it" would therefore seem to have some foundation. In fact, he murders or thieves almost without a motive; he is possessed by a demon that impels him to a breach of the law. 
How many philanthropists have acted upon the conviction that the children brought up in a thieves' quarter are ruined by evil associations alone, and that a course of moral precepts will reclaim them! There could be no greater error. And what are we to say of the misguided people who adopt from workhouses and foundling hospitals children of whose parentage they know nothing?

As Maudsley points out, there are three classes of criminals-(1) those who are driven to crime by want or adversity; (2) those who have in their natures a taint of crime which may be corrected by favourable circumstances; and (3) those of a radically bad organisation. ${ }^{1} \quad$ The last are practically irreclaimable. They are born criminals, their predisposition to crime being the outcome of morbid conditions like insanity. Gall cites cases of a predisposition to theft in which the influence of example or necessity was nil. In view of such facts, the Chinese law that punishes for treason the son and the grandson of the actual culprit is no more ridiculous than the European system of loading withincreasing terms of penal servitude the unhappy wretch to whom punishment is no deterrent. Sensual passion is hereditary, as Lucas shows, and so is gambling.

1 Maudsley's Pathology of Mind. 
The most important because the most general vice dependent upon the law of heredity is drunkenness. Every writer on physiology furnishes proofs of the existence of hereditary dipsomania, and there are few private individuals who could not point to cases of the kind within their own circle of acquaintances. Like every other physical and mental peculiarity, alcoholism is capricious in its choice of a subject, attacking some member of a family and passing over others; it must be borne in mind, however, that it assumes various forms, all traceable to a deterioration of the brain and the nerve-system.

To pass to a more agreeable aspect of the subject, Galton's laborious work on Hereditary Genius proves, to some extent, that just as mental weakness is transmissible, so also is mental power. The one case, indeed, implies the other. If vice is hereditary because of a deterioration of the physical structure, it follows that talent or genius, as the result of a superiority of brain-fibre or nerve, is equally so. Unfortunately Galton has pushed his theories to an extreme, and has thereby prejudiced the cause of moral heredity with many who are already too prone to reject it. It is twenty years since Hereditary Genius was published, and during that time a great 
advance has been made in our knowledge of the subject, especially on its pathological side. Heredity does not, in point of fact, manifest itself in the regular mathematical order which Galton's tables of eminent men would lead one to suppose. The direct transmission of mental qualities seldom extends beyond a single generation. At every stage of the male line of descent female heredity intervenes, and both the male and the female lines are liable to reversion for an unknown number of generations, while a further element of uncertainty is thrown into the case by the principle of metamorphosis. And not only are a large proportion of Galton's eminent men mediocrities, but in his mistaken zeal for making out a case that writer seems to have ignored the influence of family patronage and other fortuitous sources of social or official distinction.

Lumping together judges. statesmen, commanders, literary men, men of science, poets, painters, musicians, and divines, Galton finds that the chances of an eminent man having eminent relatives are in the case of fathers 31 per cent; brothers 41 per cent; sons 48 per cent; grandfathers 17 per cent; uncles 18 per cent; nephews 22 per cent; and grandsons 14 per cent. These totals are imposing, no doubt, but they 
are entirely fallacious. Examining them in detail, we find this strange anomaly, that whereas a statesman's chances of having an eminent grandfather are 28 per cent, a poet's chances in the same direction are only 5 per cent, and an artist's 7. Galton himself is struck by the fact that the eminent kinsmen of poets, painters, and musicians are mostly of the first degree. Could the influence of patronage be eliminated from his tables, the apparent ramification of talent in the official classes would probably diminish to a considerable extent. Even in the case of literary and artistic talent there are dangerous pitfalls awaiting the statistician. Sons have a tendency to adopt their father's calling, and even to achieve distinction in it with the help of their father's name. Family circumstances always help to determine a young man's career. There have been many families of actors, but it would be rash to conclude that their members had, all of them, an hereditary bent for the stage; example and opportunity would count for something in the shaping of their lives.

Still Galton has unquestionably a case, although he attempts to make too much of it. It is difficult to deny the existence of hereditary talent when we find that among the Bachs there were twenty eminent 
musicians, and that Landseer, Rosa Bonheur, Teniers, and Titian all belonged to painting families. Of fortytwo old masters, chiefly Italian and Dutch, no fewer than eighteen appear to have had eminent relativesa large proportion. It is certainly safer to take literary, scientific, and artistic talent as a test of heredity than official position, and Galton's statistics under that head furnish a striking proof of hereditary influence. Thus the chances of sons of eminent fathers becoming themselves eminent are shown to be, in the case of literary men, 51 per cent; men of science, 60 per cent; poets, 45 per cent; and painters and musicians, 89 per cent. Eminent brothers are somewhat less numerous than eminent sons, but still they are a very large class, showing a percentage in the above cases of $42,47,40$, and 50 respectively. By a very different process M. de Candolle in his Histoire des Sciences et des Savants has arrived at analogous results. The proportion of eminent sons of eminent fathers occurring among the foreign associates of L'Académic des Sciences during the past two hundred years would, in the absence of hereditary influence, be extremely small. Nevertheless M. de Candolle finds it to be as high as 10 per cent. 


\section{CHAPTER VII}

THROWING BACK AND THE METAMORPHOSES OF HEREDITY

Among members of the same family there is sometimes a total absence of family likeness. Brothers and sisters may resemble neither their father nor their mother nor each other, the difference extending to their moral as well as to their physical nature. Dull parents may liave clever children, and clever parents dull ones; a well-grown couple may have puny offspring; a vicious father and a colourless mother may have a most exemplary son. In fact, no limit can be set to the diversity of physique and character that may exist within a family circle. The question then arises, To what is this diversity due? We are assuming, of course, that the children between whom the dissimilarity is noted have been brought up amid the same physical and moral influences, for although 
the effect of a child's surroundings upon its character is much overrated, it is not altogether to be despised. The phenomena in question may be attributed to two causes-first, the principle of reversion or throwing back, and secondly, the metamorphoses of heredity.

The stud-book has demolished the once accepted theory of "innateness," or the spontaneous generation of virtues and vices in the individual, the breeder who has made sure of an animal's pedigree for the requisite number of generations being able to tell to a nicety what its character will be. But with men and women no such guarantee of perfection is obtainable. It takes six or eight generations to fix character in a thoroughbred horse or dog; and applying the same law to human beings, we are brought face to face with this startling fact that men derive their characteristics from an ancestry spreading out fanlike over some three hundred years, and numbering perhaps 2000 individuals. Every good quality and every defect that may have existed in any of our forefathers since the reign of Queen Elizabeth is liable to be revived in ourselves, subject to the principle that ancestral influence, as a rule, is fainter in proportion as it is more remote. Fortunately there is a 
steady average of virtue and of capacity in mankind that precludes any general deviation from "honest Nature's rule"; but it is strange to reflect that independently of fortune and of education, every man's character is evolved by a haphazard process, over which he has no control. It was indeed a sapient remark of Heine's that a man ought to be very careful in the selection of his parents.

Owing to the imperfect nature of all family records, proofs of reversion in the case of human beings are difficult to find. The recurrence of physical character after the lapse of centuries is attested by portraits, but moral character of a normal kind, except for the uncertain light thrown upon it by history, can scarcely be traced beyond the third generation. Occasionally an old family nurse is heard to declare that a boy acts just like his grandfather, whom he has never seen, but, there, direct testimony on the subject commonly ends. Yet by the analogy of the lower animals the reversion of moral characteristics after many generations may be regarded as a certainty.

Instinct is nothing more than fixity of character induced by heredity. The domestic dog, when he buries food that he will have no occasion to dig up 
again, takes after his savage progenitor, who lived in the woods. So he does also when on the floor of a room he turns round and round on the same spot before lying down, as if to make a bed in the grass. Darwin gives curious examples of this kind. Many of our acts in daily life, apparently dictated by reason, are in reality the survival of habits contracted by our savage forefathers. Nothing appears more natural to us than to open and extend the hand as a sign of frankness; but this gesture is merely a testi. mony that we carry no weapons, and have no intention of making an attack. Naturalists tell us also that to uncover our teeth in anger means that we have inherited an instinct to bite. The military spirit of civilised peoples, so deplorable in its effects, is probably inherited from savage ancestors with whom war was a necessary condition of existence!

The effects of throwing back are frequently seen in the likeness existing between nephews and uncles, nieces and aunts, cousins and other more distant relatives. The similarity of feature or of sentiment in such cases is no doubt derived from a common ancestor of the parties concerned. No other explanation seems to be possible, seeing that the individuals resembling each other have, as a rule, been brought 
up unler different conditions, and in some instances have never seen each other at all. Ribot in his Hérédité Psychologique says: "I know a nephew who bears a striking resemblance to an uncle on his mother's side. The resemblance is even more mental than physical. Both parties had an early mental development which ceased at the age of fifteen; and both subsequently fell into an inactive state that unfitted them for any sustained effort. They have tried various professions without being able to settle down in any. What makes the case the more striking is that the uncle and nephew had never come under each other's influence. The former had spent the greater part of his life in Algeria; the latter lived in France in a very respectable and industrious family. They had never, in fact, spent ten days of their lives in each other's company. Their resemblance they derived from a common ancestor, their father and grandfather." In all such cases the "latent germ" plays a part. The son does not derive his qualities from his father, but from an ancestor whose characteristics have been transmitted in a latent state through intervening generations.

Of the latent germ Darwin remarks: "What can be more wonderful than that the minute ovule of a 
good milking cow will produce a male from whom a cell in union with an ovule will produce a female, and that she, when mature, will have large mammary glands yielding a good supply of milk, and even milk of a particular quality " ? 1 The existence of the latent germ is manifested in that strange phenomenon called "secondary sexual character," female birds in old age, or after their ovaries have been removed, being known, for example, to take the habits of the male. In every individual there necessarily exists the nature of the opposite sex in a latent form, and this occasionally manifests itself in other ways than by transmission, as when a woman assumes a masculine manner or a man a feminine one. Usually these peculiarities are accompanied by certain physical indications of virility or effeminacy, the masculine woman having hard features and the rudiments of a beard, and the feminine man the smooth face or the rounded form of a woman. We cannot doubt but that latent heredity, or at least the principle of the metamorphoses of heredity, is at the bottom of all strongly marked divergences from a family type, whether physical or moral. In this way we may account for the appearance of a "black sheep" in a

1 Darwin's Variation of Animals and Plants. 
respectable family or a poet among brothers and sisters of an unimaginative cast.

The question of the metamorphoses of heredity is, if possible, still more difficult to treat than reversion. It has, in truth, been little studied, except in connection with disease, but observation, so far as it has gone, points unmistakably to the existence in this, as in other branches of science, of the great principle that "nothing is lost" - that peculiarities of body or mind, when they are not transmitted directly, become transformed in passing from one generation to another. "To look in each new generation for a return of the identical phenomena observed in the preceding one," observes Moreau, "would be to misunderstand the law of heredity. . . . The family of a man who dies insane or epileptic do not necessarily suffer from the same malady; they may be idiotic, paralytic, or scrofulous. What the parent transmits is not his insanity, but a constitutional defect which may manifest itself under different forms."

This is particularly noticeable in the case of drunkards. "A frequent effect of alcoholism," says the Swedish physiologist Magnus Huss, "is the partial or general atrophy of the brain ; this organ is reduced in size to such an extent as no longer to fill the 
cavity of the skull. Whence a deterioration of the mental faculties, which in the offspring may produce lunatics or idiots." In Carpenter's Physiology, a well-known text-book, it is stated that of 359 idiots whose parentage was investigated, 99 were found to be the children of confirmed drunkards.

No doubt there is a limit to the transmission of abnormal characteristics, either in an original or in a disguised form. Always striving after perfection, or rather uniformity of type, Nature either purifies a race of its physical and moral defects, or, if the type be too vicious, exterminates it, as in the case of the Cæsars, the Stuarts, and many other historical families.

As an example of family degeneration, Doutrebente gives the following case :-

First Generation. Father intelligent, but hypochondriac, and suffering from delusions. Dies insane. Mother nervous and emotional.

Second Generation. Ten children of the above. Three die in childhood. Daughter A is hypochondriac and emotional; daughter $B$ becomes insane at twenty; daughter $\mathrm{C}$ is weak-minded; daughter $\mathrm{D}$ has delusions and commits suicide; son $\mathrm{E}$ is weak-minded; son $\mathrm{F}$ hypochondriac; son G hypochondriac.

Third Generation. Ten children of A. Five die 
in childhood. Of the remainder two are intelligent and marry, but are childless. The third is deformed. The fourth is eccentric and extravagant. The fifth has fits of insanity. B leaves no issue. $\mathrm{C}$ has one child who is imbecile and hermaphrodite. D has a son who dies of apoplexy at twenty-three; another child of D's is imbecile, and a third is an artist, described as "extravagant." $\mathrm{E}$ has a son who dies insane, and a daughter who disappears and is supposed to commit suicide. $\mathrm{F}$ is childless. $\mathrm{G}$ has one child who is semi-imbecile. ${ }^{1}$

It is to be observed that this radically unsound family, although prolific to begin with, becomes extinct in the third generation. Another point of interest in the case is that deformity, hermaphroditism, and apoplexy are among the evils developed from insanity. Doutrebente's observations lead him to the belief that insanity introduced into a family by one parent may be worked out of it by the infusion of healthy blood, but that the offspring of two affected parents is doomed to extinction. There is no doubt but that suicide is Nature's great remedy for insanity when death by other means does not supervene, and it is a question whether the philanthropy is well

1 Annales Medico-Psychologiques, 1869. 
directed that deprives the poor maniac of this resource, and that sometimes sends him forth from an asylum, nominally cured, to propagate his imperfections.

Another instructive case of this kind is givem by Maudsley, as follows :-

First Generation. Man excessively depraved and addicted to alcoholic excess. Killed in a tavern brawl.

Sccond Generation. Son a drunkard, subject to maniacal attacks, ending in general paralysis.

Third Generation. Grandson sober but hypochondriacal, subject to delusions of persecution and homicidal tendencies.

Fourth Generation. Great-grandson born with defective intelligence, attacked by mania at sixteen. Transition to idiocy, and probable extinction of the line. ${ }^{1}$

Galton's researches show that while a particular form of talent is often inherited, especially among musicians, many great men have sons and relatives distinguished in walks of life that they have struck out for themselves. This fact may be explained in two ways. First, clever men having no particular bent towards art, science, literature, commerce, or

1 Maudsley's Pathology of Mind. 
government, are able to succeed in whatever occupation they may turn their hands to. In the second place, we may assume that there is a metamorphosis of talent as there is of disease. The family capacity that raised Heine's uncle Solomon to the position of a millionaire, by dint of metamorphosis made Heine himself a poet. Milton's father was a musician. Jeremy Bentham's brother Samuel was a general, and his nephew George a distinguished botanist. The famous Swiss family of the Bernouillis numbers among its members mathematicians, naturalists, chemists, and mineralogists. Darwin's family includes two medical men of note. Galileo's father was a musician. Examples of this kind might be indefinitely multiplied.

It is true that not a few great men could be cited who have had no distinguished relatives, Shakespeare, Cervantes, Rabelais, Scott, Voltaire, and Newton being of the number. But great ability may exist without becoming historical. Literary and artistic capacity probably finds a means of asserting itself under the most adverse circumstances. On the other hand, great commanders and administrators have to await their opportunities, and in many cases probably their opportunities never come. Clive and 
Warren Hastings began life as clerks in the service of the East India Company. The dangers and diffculties in the midst of which they were cast brought out their military and administrative talents. But what youngster in the Indian Civil Service of to-day can hope to emulate their example?

Opportunity makes the great man as it makes the thief, especially the great man who is born not to create but to rule.

The American Civil War was rich in improvised generals of a high order of ability. General Grant's chief of the staff, Rawlins, was a young lawyer who was destitute of military training, but proved perfectly equal to his position. Butterfield, a pure civilian when the war began, ended by commanding an army corps and acting as chief of the staff to Meade at Gettysburg. Sheridan's military genius was developed on the battle-field, never in the study. Grant himself gave little promise as a student, and for seven years before the outbreak of hostilities was an obscure civilian. But for the accident of the rebellion of the southern states, what would have become of this latent fund of American military capacity? If the "mute inglorious Milton" is a myth, because pens and paper are always within reach, we may conclude that there are 
possibly not a few village Napoleons and fireside Washingtons, condemned, despite their gifts, to a life of obscurity.

The transmutation of character through heredity is not always of a favourable kind. Maudsley, who regards insanity as a disease largely engendered by the worries of civilised life, observes: "There is no more efficient cause of mental degeneracy than the mean and vulgar life of a tradesman, whose soul is entirely taken up with petty gains, who, under the sanction of the customs of the trade, practises systematic fraud and theft, and who thinks to outweigh the iniquities of the week by a sanctimonious observance of the Sabbath. The deterioration of nature which he has acquired will, unless a healthier family influence serve to counteract it, be transmitted as a family heritage to his children, and may result in some form of moral or intellectual deficiency, perhaps in extreme duplicity and vice, perhaps in outbreaks of positive insanity." To put the matter concisely, "the absence of moral sense in one generation may be followed by insanity in the next," and vice versa. The existence of all forms of mental power or weakness is probably a question of brain nutrition, which would necessarily depend upon heredity. 


\section{CHAPTER VIII}

RELATIVE INFLUENCE OF THE MALE AND FEMALE PARENT

Although throwing back is a fact to be reckoned with, hereditary influence is generally strong or weak in proportion to the nearness or the remoteness of the ancestor concerned. The parents having thus to be credited with the largest share in the moulding of the physical and moral character of their children, the important question arises, In what proportion, as between the father and mother, is that influence exercised? In ancient times it was held that the father was predominant in the child, but modern physiologists, although perplexed by the singular diversity of the facts observed, have come to the conclusion that the influence of each parent is about equal, not in individual cases, but in the main. All characteristics transmissible by the father are trans- 
missible by the mother likewise. It rarely, if ever, happens, however, that an exact balance of the paternal and maternal qualities is struck in the child. One or other influence preponderates-it may be the father's or it may be the mother's; and this is not to be wondered at when we reflect that in every act of generation the rival heredities of the parents, so to speak, are brought into conflict, and that the offspring is a more or less fortuitous combination of the two.

As Lucas puts it: "There is no individual who can be said to bear in his organisation or in his mode of life the stamp of one of his parents alone. In one part of his system the mother, in another the father, predominates ; certain organs or faculties may be derived from the mother, others from the father, and in others, again, the parental influence may be equal." Girou de Buzareingues, whose book, De la Generation, is a curious storehouse of facts and experiments, declares that physical configuration, including will and intelligence, is transmitted more frequently and more perfectly from father to daughter, and from mother to son, than otherwise; but that the mechanism of the vital functions, including the sentiments, passes usually from parent to child of the same sex. ${ }^{1}$

3 Baillarger, analysing 571 eases of hereditary insanity, found 
Without gainsaying Girou's observations, later writers, taking a wider survey of the facts, are disposed to think that no absolute rule on this subject can be laid down. Even when a mother's or a father's characteristics are not apparent in a child, they are probably present in a latent form, and capable of being revived in the succeeding generation. A Newfoundland dog breeding with a retriever may have a mixed litter, some of the pups being Newfoundlands and others retrievers to all appearance. But these pups are neither genuine Newfoundlands nor genuine retrievers. The apparent Newfoundlands, if crossed by genuine Newfoundlands, are apt to throw a litter containing a strong admixture of the retriever, and vice versa. And so with the moral nature. Darwin quotes a case showing that a breed of harriers, crossed with a bull-dog, retained the bull-dog's qualities of

that 225 fathers transmitted the malady to 128 sons and 97 daughters, whereas 346 mothers transmitted it to 197 daughters and 149 sons. Official statistics presented to the French Government in 1860 yield similar results. Of 1000 male lunatics, 128 derived their insanity from their father, 110 from their mother, and 26 from both parents; while of 1000 female lunatics, 130 derived their insanity from their nother, 100 from their father, and 26 from both parents. In these figures it will be seen there is a slight tendency in favour of direct transmission from father to son, and from mother to daugliter. 
courage and tenacity long after the physical traces of the crossing had disappeared.

A curious case of crossing in the human species is recorded by Ribot. Lislet-Geoffroy, a civil engineer in the Isle of France, was the son of a Frenchman and of a negress of the lowest order of intelligence. Physically he was a perfect negro, having the features, colour, hair, and odour of his mother's race. But morally he was so much of a European that he was able to overcome the prejudices of caste, to raise himself to a professional post of distinction, to be upon terms of intimacy with the most exclusive families, and to be elected a corresponding member of L'Académie des Sciences. It is seldom that the physical and moral natures of a child are so evenly apportioned between its parents. For the most part, no line of demarcation can be drawn between the paternal and the maternal influence. Consequently the hybrids known as mulattoes, quadroons and octoroons represent a far from uniform admixture of white blood, one such subject taking largely after his father, another after his mother, and so on.

There is a prevalent opinion that the crossing of distinct races of mankind is beneficial. The majority of physiologists do not favour this view. Crossing 
appears to have a special effect in reviving latent qualities, but these of course may be bad as well as good, and there is nothing to warrant the supposition that when a superior race is crossed with an inferior one the product can be better than the best elements composing it. While the offspring of a white man and a negress may be morally or physically equal to the white man, experience shows that as a rule the father's qualities in such cases suffer deterioration in the child. Crossed races are more or less inferior to their best original stock. Many travellers have noted this fact, from Humboldt downwards. The Pitcairn islanders are sometimes cited as an example to the contrary. In that large family group, however, there was a pretty equal admixture of European and Polynesian blood, inasmuch as the four mutineers of The Bounty and the ten native women who were the real founders of the community lived promiscuously together; and although their offspring were subsequently found to be superior to the native stock, they could not be said to be better than their white progenitors. The hybrid Jews of the east of Europe have an evil reputation, arising probably from the fact that they spring from the dregs of their respective races. 
From time to time the English public have been amused by reading of young negro barristers and missionaries, mostly half-bloods, who, after being educated in London or at Oxford, have returned to their native place and relapsed into a state of savagery - "gone fanti," as the saying is. This has been humorously referred to as a proof of the inferiority of civilisation to barbarism in the estimation of those who have tried both. In reality it attests the preponderance of hereditary instinct over education, the instinct in the case of mulattoes being derived from the negro parent. The French mis. sionaries in China have experienced the truth of this principle also in the case of young Chinese converts.

When wolves and dogs are crossed, some of the resulting litter resemble the mother in outward appearance, others the father. But this curious fact is noted, that the whelps looking like wolves frequently have the dog's nature, and those looking like dogs the wolf's. The offspring of the stag and the cow have the male parent's timidity, and also his agility in clearing fences. Girou mentions the case of two shrewish sisters who married men of quiet and gentle disposition. Of the offspring in each instance all the sons were like the mother in 
character, while the daughters had the temperament of their father. It is certain that even when outward resemblance is absent, and when there is no possibility of imitation, children will take after one or other of their parents in peculiarities of thought and feeling, and proneness to certain constitutional disorders.

The mule, the offspring of the he-ass and the mare, is essentially a modified ass in appearance, while the hinny, the offspring of the stallion and the she-ass, is essentially a modified horse. A monster engendered by a bull and a mare being dissected at the Ecole Vétérinaire of Lyons, some curious physiological facts were disclosed. The case is quoted by Lucas. The animal had the muzzle and the eye of the bull, the teeth and stomach of the horse-it did not chew the cud-the tongue and spleen of the bull, and the womb and viscera of the horse. From this strange example it is clear that physical structure may be derived in pretty equal measure from both parents. The fact is, moreover, attested by anatomists both with regard to animals and human beings. Lucas observes that a father may transmit to a child the brain and the mother the stomach, one the heart, the other the liver, one the kidneys, the other the bladder, and so on. 
Certain individuals, male and female, exercise a preponderating influence in generation. They have the faculty of overcoming the influence of the other parent, and stamping their own peculiarities upon the offspring in all circumstances. This Darwin calls prepotency, remarking that but for the existence of the principle it would be difficult to explain the transmission of characteristic traits in certain families, notwithstanding the marriage of the males with women of the most diverse origin. The emperors of Austria furnish an example in point, and so, according to Niebuhr, did certain Roman families. Sometimes the father's prepotency is manifested in all his children; at other times in the sons alone or in the daughters alone. And what we call prepotency in one parent may be only the excessive weakness of the other, so far as the power of transmitting qualities is concerned. Michelet in his History of France observes that the French kings during the most dissolute period of the monarchy seemed to be incapable of engendering sons in their own likeness. "The heir to the throne," says that writer, "invariably took after his mother. Like her, he was essentially a foreigner. The succession almost always had the effect of an invasion. Catherine and Marie de Médicis gave us pure Italians; 
so did La Farnèse. Louis XVI, on the other hand, was a true Saxon, more German than the Germans themselves."

The age and the health of parents have an important effect upon the offspring. Many authorities assert that a child conceived in drunkenness is likely to be epileptic, insane, obtuse, or idiot. Quatrefages remarks: "At Toulouse in the course of my medical career I met with an artisan and his wife, both sound of mind and body, who had four clildren. The two elder children were quick and intelligent; the third was half idiot and almost deaf; the fourth was like the two elder. From the statements of the mother, who was distressed beyond measure at her third child's condition, I learnt that it had been conceived while the father was under the influence of drink." Dejerine not only supports this view, but states that any temporary perversion of the cerebral state of parents, however caused, at the time of conception, affects the child. He instances the case of the children conceived during the siege of Paris, who from their weakly condition are called les enfants du siege. ${ }^{1}$

Twins usually bear a closer resemblance to each other than to their brothers and sisters born at a 
different period; and the reason generally assigned is that they are conceived under precisely similar conditions. If so, it follows that the difference existing between ordinary members of a family is due to their being born at considerable intervals of time, and therefore under changed conditions on the part of their parents. At the same time, while physically alike, twins sometimes differ in disposition. The last years of the fanous Siamese twins, it is said, were made miserable by the quarrels arising from the different tastes of the brothers, and the opposite views they took of the American war.

One of the most curious forms of heredity presents itself in the case of a widow who, marrying again, has children by her second husband strongly resembling her first, although the latter may have been dead for years. The fact is unquestionable, and it was long a puzzle to physiologists, who were inclined to believe that the woman's imagination exercised some influence upon her offspring. Goethe adopts this view in his Wahlverwandtschaften, where Charlotte, a virtuous wife, gives birth to a child resembling not her husband, but the captain with whom she is in love, and also Ottilie, her rival in her husband's affections. The idea thus expressed of the influence of the mother's 
imagination continues to be very prevalent at the present day. But it is erroneous. It did not even accord with the facts ascertained in Goethe's time, for the manifestation of heredity by influence, as this class of phenomena is somewhat ineptly called, is frequent in the case of certain of the lower animals, such as pigs, which are not supposed to be governed by imagination. A domestic sow having bred once with a wild boar, or a boar of a particular breed, continues in subsequent litters to produce young exhibiting a greater or less admixture of the strange blood. Breeders of animals are well aware of the danger caused to the purity of a stock by a single case of promiscuous crossing. No work on breeding is complete without a reference to the famous quagga colts. An English mare was crossed in 1815 by a quagga, a spotted ass of Africa. The mule so bred was spotted like its father. Its parents were never again brought together. In 1817,1818 , and 1823 the same mare was crossed by Arab stallions, and in each case she produced a colt spotted like the quagga. Breeders have never forgotten this case, which was an epochmaking one in their craft. For a long time they were unable to explain it. Darwin, however, discovered the key to the mystery in studying the fertilisation. 
of plants. He observed that foreign pollen not only affected, in accordance with its proper function, the germ, but also the tissues of the mother plant, and that by this means crossing had an effect upon the subsequent generation. "The analogy from the action of foreign pollen upon various parts of the mother plant," Darwin remarks, "strongly supports the belief that with animals the male element acts directly upon the female, and not through the crossed embryo." 1 A wife becomes inoculated, so to speak, with her husband's qualities. Apart from Darwin's hypothesis, it is reasonable to suppose that the circulation of the mother's blood through the foetus should, in process of time, affect the mother's physique. We need no longer be astonished at the fact, therefore, that a child born of adulterous intercourse may resemble its legal as well as its actual father.

1 Darwin's Variation of Animals and Plants under Domestication. 


\section{CHAPTER IX}

\section{CONSANGUINITY}

THE marriage of persons nearly related in blood is generally believed to be hurtful to the species. Malformations, scrofula, blindness, deafness, sterility, paralysis, and insanity have long been supposed to be entailed upon the unhappy offspring of consanguineous unions; and by the great Hindu, Mosaic, Roman, Christian, and Mussulman codes such unions are rigorously condemned. In its origin this idea of the evil effects of the alliance of near kin was probably religious; it can hardly have been scientific. A repugnance to consanguineous unions has grown up in civilised communities, but the natural instincts, whether of man or of the lower animals, do not forbid them. Among many primitive peoples, including the Persians, the Spartans, and the Egyptians, brothers and sisters were allowed to marry. A son of the 
notorious Ninon de l'Enclos made violent love to his mother until she disclosed her identity, of which he had been ignorant, whereupon he shot himself dead; and Huth mentions the case of a Turkish pasha who discovered by chance that one of his wives-originally, like himself, a Circassian slave-was his own sister.

Of recent years the question of the effects of consanguinity in marriage, supposed to have been settled by the collective experience of the world, has been reopened by scientific men, notably by George Darwin, son of the eminent naturalist, and A. H. Huth, the latter of whom has sought to demonstrate by the most exhaustive research that the reputed evils of consanguineous unions are fanciful. ${ }^{1}$ George Darwin calculates that in England the proportion of consanguineous marriages to marriages in general bears no excessive relation to the number of afflicted children. Pursuing a more extended line of inquiry, Huth declares that small and isolated communities in which consanguineous unions abound are not specially subject to physical or mental disorders; and that as regards sterility, marriages between cousins are actually more prolific than others, the parties being usually married young.

1 Huth's Marriage of Near Kin. 
Where then does the truth lie? A study of the general principles of heredity solves this as it does many other social problems. In theory consanguineous unions may be harmless enough; practically it is well to avoid them. We have seen that diseases and other physical peculiarities run in the blood. If a family could be pronounced absolutely perfect in mind and body, the intermarriage of its members would probably be an advantage. Raisers of prize stock have found the process of in-and-in breeding in some cases to be distinctly beneficial. But what family is perfect? We have all a constitutional weakness of some sort, and heredity warns us that when two persons having the same complaint marry each other, the evil is intensified in their children. Double heredity is notoriously disastrous, for example, in cases of insanity, and by analogy we may conclude that it is no less so in heart disease, consumption, and other constitutional maladies. All family characteristics, good or bad, are unquestionably accentuated by consanguineous marriages.

The harmlessness of such unions in certain cases does not imply their harmlessness in all; cousins who are fond of each other can never be certain that their marriage will not foster some latent family im- 
perfection. Even where no positive evil exists on either side, heredity by metamorphosis, as we have seen, may produce a distinctly neuropathic condition, the preliminary to insanity, and other troubles, and this is a matter which would naturally escape the notice of the statisticians. Moreover, we must bear in mind that such terms as cousin cover many different degrees of actual relationship. $\mathrm{X}$ has a son, we will say, resembling his mother. The brother of $\mathrm{X}$ has a daughter also resembling her mother. The young people are first cousins, but they are physically and morally as unlike each other as strangers. On the other hand, X may have a daughter taking after himself, and his brother a son who likewise takes after his father; these cousins will be as closely allied as brother and sister. It is manifestly unsafe, therefore, to conclude that this or that class of marriage is innocuous from bare statistical returns, conveying no information as to particular cases.

The statistics of insanity in connection with consanguineous marriages in different localities vary enormously. Huth, remarking upon such discrepancies, considers the higher figures to be worthless as evidence, on the ground that they are obviously compiled by biassed persons. But they are just what 
heredity teaches us to look for. The population of a certain island or district acquires the taint of insanity, and consanguineous marriages then tend to aggravate the evil. In the primitive communities cited by Huth, such as the island of St. Kilda, Pitcairn Island, Iceland, etc., and indeed among all savage races, we should naturally expect consanguineous unions to be more or less harmless, because of the rarity of disease which is so largely bred by the conditions of civilised society. Insanity, for example, is a disease of civilisation, arising from the excessive wear and tear of commercial, literary, and artistic life, or from the enervating influences of wealth and luxury. Were insanity in all its forms to be swept out of the world to-morrow, says Maudsley, it would at once be bred again in civilised communities. Other classes of disease that may be said to dog the steps of civilisation are those arising from overcrowded and unsanitary dwellings and long hours of work. The puny lads and the flat-chested girls swarming in great towns and cities are essentially the product of civilisation; and as each family group suffers from a particular defect, which would be aggravated by the intermarriage of its members, it is mathematically certain that consanguineous unions, if as common, for example, in 
London as in St. Kilda, would lead to frightful evils. We are therefore driven to conclude that the great lawgivers of mankind have been wise to discourage the marriage of near kin, and that it might be well even to place first cousins within the forbidden degrees of relationship.

We are speaking from the point of view of morbid heredity alone. What effect in-and-in breeding would have in developing superior qualities of body or mind it is impossible to state, for the simple reason that the experiment has never been made. Such an experiment of course would have to be continued over many generations before its results could be clearly ascertained; but an intensification of the good as well as of the bad qualities of parents of the same blood might confidently be looked for in the offspring. Thus two first cousins of strong musical talents marrying would be likely to produce children having an exceptional capacity for music. The numerous family of the Bachs, as organists or music teachers freely intermarried, and were very prolific in musical talent, which may depend in part upon the structure of the ear and of the fingers, as a painter's perception of colour does upon the apparatus of the eye. But as the morbid germ is always present in our constitu- 
tions, while a particular talent may not be, it is certain that the experiment of in-and-in breeding in the human race would be attended with considerable risk to the individuals concerned. 


\section{CHAPTER X}

\section{BLUE BLOOD}

HEREDITY is the corner-stone of all the aristocracies of the world, but various influences have combined to nullify the claims of any families or classes now existing to what may be called purity of stock. Whatever their pretensions may be, modern aristocracies freely admit plebeian blood on the female side. And it is well for them that they do, for we have every reason to believe that privileged classes existing upon any other basis are doomed to decay and extinction. History abounds in examples of the pernicious effects of privilege, extending from the Citizenship of Athens and the Patrician Order of Rome to the curious corporation of Free Burgesses of Newcastle mentioned by Doubleday. Privilege means exclusiveness, and exclusiveness means deterioration. The more exclusive a class becomes-that is 
to say, the more its members are given to marrying within their own circle-the briefer is its existence. As the result partly of luxurious living, partly of the in-and-in process of breeding, social castes develop in course of time a neuropathic condition, which classes them among the unfit, and they die out like a family which has contracted too strong a taint of vice and insanity. Consanguineous marriages, although more prevalent in aristocracies than in the masses of the people, are not sufficiently so to materially influence the vital statistics. But the effect of privilege is to induce men and women to choose consorts brought up under the same influences as themselves, living the same life, cast in the same mould, suffering from the same functional and intellectual troubles, and thus a species of artificial consanguinity is established which in the end is as disastrous as the real. History shows us this principle at work in aristocracies, but exclusiveness in any class of the community, however humble, would no doubt be productive of similar evils.

The most exclusive caste in the world is that of royalty, and it is among reigning families accordingly that we find neuropathic conditions most highly developed. From an exhaustive inquiry into this 
subject, extending from the Cæsars to the Georges, Dr. Paul Jacoby has felt justified in laying it down as a principle that the assumption of power by one class over another is a crime unfailingly resented and punished by nature. ${ }^{1}$ The degeneration of the Cæsars was terribly rapid and complete, beginning unmistakably with Augustus. Roman society as a whole was at that time so corrupt, however, that the Cæsars may be taken rather as an example of family than of class degeneracy, the conjunction of the gens Julia and the gens Claudia in Caligula being an illustration of the worst effects of consanguinity in promoting weak-mindedness, depravity, and downright mania. In dealing with the modern dynasties of Europe, Jacoby finds abundant material for supporting his theory. The subject being one of some novelty and importance, it may be well to indicate in a few words the French writer's line of research, which has been pursued with striking results by W. W. Ireland in the case of the Russian dynasty of the Romanoffs. ${ }^{2}$ No reigning family would appear to be sound. Passing over Jacoby's analysis of the various Savoy, Spanish, and Portuguese dynasties-a uniform record 1 Jacoby, Études sur la Sélection dans ses Rapports avec l'Hérédité chez l'Homme.

${ }^{2}$ W. W. Ireland, The Blot upon the Brain. 
of vice, insanity, and sterility - we come to the royal families of England.

In the Plantagenet period the rival houses of Lancaster and York, Jacoby declares, were both degenerate, the former being a family of fools and imbeciles, the latter of knaves, including Richard III, whose paralysis and deformities indicated the neuropathic nature of the family villainy. The Tudors were in similar case. Henry VIII was cruel, sanguinary, and lascivious; his son Edward VI died at eighteen,--and a tendency to early death as well as sterility, be it remembered, is an unfailing sign of family degeneracy,-while his daughter Mary was fanatical and childless, and his other daughter Elizabeth eccentric, avaricious, cruel, and malformed. Among the Stuarts insanity declared itself as early as the time of James V, and through Mary Queen of Scots the taint was communicated to James I. of England, who was foolish, fanatical, cowardly, slovenly, and given to stuttering. To the daughter of James I, Elizabeth, who married the Elector Palatine Frederick V, and who served ultimately to bring the Crown of England to the Hanoverian dynasty, we shall presently return. Charles I.to follow the direct line of the Stuarts-was perfidious and cowardly; Charles II depraved, epileptic, and 
without issue; the brother of the latter, James II, was treacherous, vindictive, mendacious, cruel, and ridiculous to boot; Mary, daughter of James II, was weak-minded and childless; and Anne, although prolific, had not a healthy or long-lived family. Finally Charles Stuart the Pretender, the last of his line, was illiterate, drunken, paralytic, and died insane.

The Hanoverian family fares no better at Jacoby's hands. Elizabeth from her marriage with the Elector had many children. Several died young. Of the remainder one left a daughter who died without issue; two others were childless; and yet another died insane at thirty-nine. Sophia, the youngest daughter of Elizabeth, and sister of the unhappy lunatic, became heiress to the English throne. Did she leave the family taint behind her when she quitted Germany in order to take up her ancestral heritage in this country? Jacoby finds an answer to this question in the debaucheries and excesses of the four Georges, in one of whom the positive insanity of the Stuarts reappeared. Since then, happily, the English Crown has passed into a healthy line. It is inadvisable for obvious reasons to pursue our inquiries as far as the present condition of the royal caste in Europe. Suffice it to say that not a few examples of the truth of 
Jacoby's argument could be drawn from the history of the past ten years alone. ${ }^{1}$

There can be no doubt that the wider the basis of selection adopted in all cases the better. The most degenerate and worthless aristocracy in the world was that of France prior to the Revolution, and it was also the most exclusive. In mediæval times French nobles who had married plebeian women and their heirs to the third generation were adjudged unworthy to take part in the tournaments. Benoiston de Châteauneuf, in his Mémoire Statistique sur la durée des familles nobles en France, proves the average life of a French noble family to be about three hundred years. At the end of the seventeenth and the beginning of the eighteenth centuries the haute noblesse d'etat frequenting the French Court looked like une societe de malades. The bourgeoisie of Berne was formerly a caste; and of 487 families admitted to it between 1583 and 1654, there remained in 1783 only 168, or about one-third. The English peerage has been justly described by Macaulay as the most democratic in the world. For that reason it is probably the most robust

1 "We have seen a list of more than twenty princes and princesses [of the royal families of Europe] under medical care for brain affections, and the number displays a perilous tendency to increase." -The Economist, 9th February 1889. 
and influential. Yet although constantly refreshed with plebeian blood, either by the marriage of peers outside their own circle, or by the ennobling of commoners, the English peerage has not escaped the degenerating influence of caste. Burke states that all the English dukedoms created from the establishment of the order down to the accession of Charles II are extinct, with the exception of three merged in royalty, and that only eleven earldoms remain out of the many created by the Normans, Plantagenets, and Tudors. Galton believes intermarriage with heiresses to be a notable agent in the extinction of noble families. We believe, on the contrary, that the free alliance of English nobles with commoners has been the salvation of the English aristocracy. As an indirect proof of the operation of the neuropathic principle in the privileged classes, it may be remarked that, while unquestionably prone to degenerate, those classes live under conditions apparently conducive to vigour and longevity. Members of noble families, for example, are exempt from much of the wear and tear of ordinary life, and in the event of illness obtain the best medical advice and treatment. Moreover, they are under little or no temptation to limit the numbers of their children. 
From these facts it would appear that the popular belief in the virtues of blue blood, per se, stands in need of revision. Social caste is not without its advantages, establishing as it does a certain esprit de corps which has given rise to the proverbs Noblesse oblige and Bon sang ne peut mentir. It has often been observed that young officers of good family, animated by pride of birth, are exceptionally brave on the battle-field, and the existence of a leisured and wealthy class tends to promote culture and refinement. But unfortunately blue blood, in the form of class exclusiveness, signifies not the improvement but the deterioration of the type. The ablest men, of all ages and countries, even in statesmanship, have been commoners, and not a few of them, like the elder Herschel and Faraday, have risen from the humblest ranks. The existence of an aristocracy may supply a social want by ministering to our innate and wellfounded conviction that men are not born equal. But the various races of the world have not so far been able to create and maintain an aristocracy upon a logical and scientific basis. Heredity has been recognised only to be misapplied, succession througl males ignoring the important element of female influence in generation. Probably this form of succession has been 
adopted, as Herbert Spencer supposes, because of the greater cohesion and discipline it ensures in ruling families by means of the personal authority of their clicefs, and also because it favours ancestor-worship. But clearly an aristocracy which asks no questions as to the origin, the capacity, or the disposition of its female recruits cannot pretend to be made of much finer clay than the rest of humanity. That this fact is advantageous to the class is our contention. Logically, however, it destroys the basis of all class privilege whatever. What is the usual origin of a noble family? A man distinguishes himself in the field or in the council chamber, and is rewarded for his services with a title. His wife is a woman, we may suppose, of an inferior type. Do the offspring of this ennobled couple inherit exclusively their father's qualities? By no means; we have shown in a preceding chapter that heredity is practically as powerful on the female as on the male side, and it follows therefore that the transmission from father to son of title and prerogative implies no corresponding transmission of physical or moral qualities. As a matter of fact, hereditary nobility, especially when carried beyond the second generation, is an affair of names and titles merely. 
Of this fact the world is becoming dimly conscious. Otherwise what means the growing deference paid to men of ability by all social castes, even the highest? The distinguished man of letters or science now meets the head of the house of Vere de Vere upon equal terms. At a Belgravian dinner-table a poet may wrest the place of honour from a duke. It has not always been so. It was not so when Shakespeare humbly solicited the patronage of the Earl of Southampton, or when the denizens of Grub Street grovelled at the feet of any nobleman who deigned to throw them a crust. It is not so even now in those countries which bring up the rear of civilisation. Neither in France nor England would any social caste dare to assert the privilege still exercised, say, by the nobility of Russia or Spain. It is true we continue to be saddled with an hereditary House of Lords, but it has long been deemed expedient that its benches should be filled up by more or less distinguished commoners. This system of democratising the peerage is of course a compromise. Like all compromises, it can only be transitional. It mitigates the evils of caste, but it leaves their root untouched, seeing that the distinguished commoner who is made a peer to-day transmits his privilege 
to possibly, nay, probably, unworthy descendants to-morrow.

Assuming social grades to be a necessity, two methods of constituting what we may call nobility suggest themselves. The first is the creation of an hereditary nobility which shall be noble not only in name, as at present, but in fact. Theoretically this course is feasible. Practically, it can never be more than a speculative thesis. It is impossible to conceive that any class of men would consent for generations to have their wives chosen for them and their lives controlled by some permanent Scientific Committee, and no means but this would ensure the development of a special race. The other method of maintaining a peerage is election pure and simple, without reference to heredity. This has already been tried successfully enough. Life peerages, created at present for legal purposes, are the thin end of the wedge which will ultimately destroy hereditary privilege. When our hereditary legislators accepted the principle of life peerages they signed the death warrant of their order. 


\section{CHAPTER XI}

THE PROCREATION OF GENIUS

MaNy writers, from Spurzheim to Galton, have deemed it possible, by means of judicious marriages practised for several generations, to create a race of highly gifted men. The analogy of the stud-book certainly seems to favour that idea, but the feasibility of the experiment, we believe, depends entirely upon what special qualities are sought to be developed. That nature is progressive we know. The mental capacity of the average European is now much higher than that of his primitive ancestor, and no limits can be set to his advancement. If, therefore, progress is possible, it may obviously be hastened or retarded by circumstances, and the point to be settled is how advantage may best be taken of this principle.

Possibly it will be found that Nature's notions of fitness and ours are essentially different, and that pro- 
gress does not exactly lie in the direction commonly supposed. If by a specially gifted race the theorists mean a race of inspired poets and painters, we can unhesitatingly tell them that their dream is not to be realised. So much the study of heredity places beyond doubt. Dryden's saying that "great wits are sure to madness near allied" expresses a sober scientific fact, pathology proving conclusively that what we call genius is an unwholesome or at least an unbalanced condition of mind. "In families where there is a strong disposition to insanity," says Maudsley, "one member may sometimes suffer from one form of nervous disease, another from another form; one perhaps has epilepsy, another severe neuralgia or hysteria, a third may commit suicide, a fourth may become maniacal or melancholic, and it sometimes happens that the fifth evinces remarkable artistic talent." The same authority further observes: "There is a third-rate artistic or poetic temperament altogether wanting in sobriety, breadth, and repose, and manifesting itself in intense but narrow idealisms of an extravagant and even grotesque character, or in caterwauling shrieks of emotional spasm put forth as poetry, which closely resembles the phthisical temperament, and which is 
likely to breed insanity." Writing as a mad doctor, Maudsley selects extreme cases in illustration of his views, but the type of genius upon which he looks with suspicion is clearly indicated in the foregoing passages. In current speech the term genius is so loosely employed as to cover a great many forms of natural ability. Thus both Byron and Bismarck may be indifferently spoken of as geniuses, although the poet is of a wholly different order of intellect from the statesman. Many men achieve distinction by dint of sound judgment, hard-headedness, self-confidence, and perseverance. These are hardly to be reckoned geniuses, however great a place they may take in the world's history. The word is more fitly applied to men of that intensely susceptible artistic temperament which in art or poetry works by "inspiration" rather than by reason. The difference between talent and genius is well defined by the saying that "talent does what it can, genius does what it must." The man of talent, who by skill, shrewdness, penetration, and untiring energy, combined it may be with refinement and taste, commands the admiration of his fellows, may be a very noble animal, a creditable and efficient product of evolution; it is highly probable that such a nan would distinguish himself in more than one walk 
of life. But the inspired poet or painter is essentially narrow in point of general capacity; the whole force of his nature is exerted in one direction. His genius is the result of a disproportionate development of some particular faculty; in other words, it means a disturbance of his mental equilibrium, and therefore belongs to the order of neuropathic phenomena.

Let us take the three great European poets of the last generation-Byron, Goethe, and Victor Hugoand see what instruction their history yields, from the pathological point of view. Byron's eccentricities are well known; they manifested themselves in unbridled passion and melancholia. The tumultuous state of his feelings is well indicated in a passage of his diary: "This journal is a relief. When I am tired, as I generally am, out comes this and down goes everything. But I can't read it over ; and God knows what contradictions it may contain. If I am severe with myself (but I fear one lies more to oneself than to anybody else), every page should confute, refute, and utterly abjure its predecessor." And this from a young man who, as he himself put it, had awoke one morning and found himself famous-a poet who had the world at his feet and to whom apparently no element of human happiness was 
lacking. The young wife, who left him after a year of wretched married life, declared that Byron was insane, and offered to furnish no fewer than sixteen evidences of his insanity. But the details of the quarrel were hushed up. Byron was not a lunatic; he was merely a poet of an extraordinarily fervid imagination, and singular as it may seem, the law of heredity enables us to couple his deformed foot with the disorders of his mind. Society judged him harshly. In reality his faults were not his own, but those of his family stock. His proud, strange, impetuous, impracticable nature was a heritage. On both sides his ancestry was corrupt, his father, Captain Byron, being notorionsly licentious and prodigal, and his mother a woman of passionate extremes. It was impossible that a child of normal or healthy constitution could be engendered by such parents. Fortunately the poet had no brothers or sisters; they would probably have been doomed to insanity, crime, or early deathto all the evils, in short, which, together with genius, are the recognised outcome of the neuropathic condition.

The case of Goethe is peculiar. We select it because of its very difficulty, for the theory is valueless which breaks down in the face of facts. Admittedly science has not yet mastered all the laws of 
the variation as well as the reproduction of species, but in its search for truth it has unquestionably found a clue, and Goethe's life and parentage are at least full of suggestion to the inquiring mind. Goethe, we may observe, if a genius at all in the proper sense of the word, was not one of the Byronic type. He was much more of a philosopher than a poet. Common sense was his main characteristic. As his biographer Lewes has remarked, "His naked vigour of resolution, moving in alliance with steady clearness of intellect,produced self-mastery of the highest kind." Well, how came this master-mind into existence? On his father's side Goethe had an ancestry of tailors. His grandfather, Frederick, the son of a furrier, was a tailor, and married a tailor's daughter. All the children of this union died young, and their mother soon followed them to the grave. Then Frederick married Frau Schellborn, the daughter of another tailor, but a widow and the keeper of a hotel. Of this union was born Johann Caspar Goethe, father of the poet. Johann Caspar was a lawyer-a cold, stern, formal, pedantic, but truth-loving, upright-minded man. He had a well-built frame and an erect carriage, and was greatly respected if little loved. He married a girl much younger than himself-Katharina Textor, the 
descendant of a long line of civic functionaries and lawyers. This was Goethe's mother, and sle was a woman of a simple, hearty, joyous, affectionate nature, at the same time possessed of much of that shrewdness and knowledge of character which goes by the name of mother-wit. Nothing could be more eminently respectable or middle-class than Goethe's parentage. What there was in the union of the hard, unsympatheticlawyer and the bright, expansive, sunny-natured girl, his wife, that it should produce one of the greatest intellects of the world, it is hard to tell. Goethe himself believed that he had inherited his father's physique and judgment, in conjunction with his mother's happy disposition and love of storytelling; and his biographers have affected to trace nearly all gifts to one or other of his parents. The fact remains that Goethe was the offspring of a couple whose union could not per se be regarded as especially advantageous. Certain abnormal circumstances in the case claim attention. The natures of the poet's father and mother were wholly distinct. Were they complementary or antagonistic to each other? Goethe's mother was married at seventeen to a man whom she did not love, her distinguished son being born a year after. What 
was the precise effect of this apparently ill-assorted relationship upon the constitution of the child's mind? These questions we might have been able to answer had the poet's five brothers and sisters lived to furnish us with an opportunity of comparing their dispositions and aptitudes. Strange to say-and this is a fact of some significance-they all died young. Cornelie Goethe saw her twenty-seventh year, but another sister succumbed at two years; and of Goethe's three brothers, Herman Jacob died at seven, Johann Maria at three, and George Adolf at twelve months. Was this extraordinary mortality of the family the result of certain abnormal conditions of mind or physique which by a happy and fortuitous combination in his one case made Goethe the man he was? Perhaps. Cornelie, the cause of whose sudden death is not recorded in the family letters, was peculiar in manner and appearance. Goethe in his autobiography describes her as an "incomprehensible being," with wonderfully brilliant eyes, while "the lineaments of her face, neither striking nor beautiful, indicated a character which was not and could not be at union with itself." Finally we have to note that Goethe's mother died of apoplexy-a common accompaniment of the neuropathic condition. 
In dealing with Victor Hugo we tread upon surer ground. The French poet had not a few of the characteristics of the neuropathic subject. His genius developed itself in his boyhood; he was flighty, unteachable, self-centred, and wholly incapable of calm judgment. Of his two brothers, Abel showed literary talent; the other brother, Eugène, became insane at twenty. It has pleased the poet himself and his biographers to conclude that he inherited much of his individuality from his mother, née Sophie Trébuchet. Between mother and son there existed certainly a strong likeness of feature, judging by their portraits. But of moral resemblance there was little. The published letters of Madame Hugo, written about the time of her marriage with Major, afterwards General Hugo, and during the poet's boyhood, exhibit her as an orderly, thrifty, and industrious housewife, and as a good mother also, bright in disposition and solicitous for the welfare of her children. Happily there are many mothers of that stamp in the world. Sons like Victor Hugo, however, are rare; and we have to look further into the family history to understand what prompted the youthful Victor to write in his scrap-book, "Je veux être Chateaubriand ou rien," and what furnished him, above all, with the means of 
eclipsing his literary model. We believe the poet owed his genius to his father. Major Hugo, although a soldier by profession, appears to have been a somewhat erratic personage, with a taste for music and drawing, and especially for dabbling in literary work. As a soldier he contrived to lose the confidence of his chiefs. While stationed at Marseilles, shortly after the birth of Victor Hugo, he fell into disgrace of some kind. "Il eut des ennuis" is Victor Hugo's own record of the incident. What these diffculties were we have no means of knowing. They resulted, however, in Major Hugo's retirement, and although subsequently made an honorary general, he never recovered his military credit. Not many years after their marriage. mrreover, Madame Hugo was constrained to apply for and obtained a separation from her husband. It is not uncharitable to suppose that the poet's father was one of those persons who are said to have a bee in their bonnet. At his death a large number of manuscripts were found in his desk, in the shape of stories, plays, and memoirs, proving him to have literary aptitudes of a somewhat extravagant kind.' The cacoethes scribendi of the father became the brilliant poetic genius of the son.

1 Les Ascendants de Victor Hugo, by Macé de Challes. 
Such are the mysteries of Nature's crucible! The same elements that constitute the illustrious Victor Hugo go to the making of his poor demented brother Eugène, who also in his boyhood was a poet of considerable promise. ${ }^{1}$ In Victor Hugo's daughter Adèle the insanity of the family reappeared.

Among English poets and men of letters it may be noted that Swift, Southey, and Cowper became insane, that Walter Scott was paralysed, and that Milton, Dryden, Addison, Coleridge, and Campbell had deformed, insane, or imbecile children. Enough has been said to prove the danger of assuming that the man of genius is necessarily a sample of Nature's finest handiwork. Genius borders so closely upon insanity in many cases that any endeavour to transmit it artificially would probably defeat itself. Indeed the crossing of one gifted family with another of the same mould would almost certainly result in a species of consanguinity and in consequent degeneracy. Every man of genius, says M. Renan, represents the accumulated mental capital of several generations. The capital is dissipated-transformed into literature or art-and the family line is impoverished for a time

1 Victor Hugo. Raconté par un Témoin de sa Vie (who is sup. posed to have been Madame Hugo). 
like a field from which a heavy crop has been taken. This is a pretty figure to look at on paper, and seems to harmonise with the observed fact that men of genius have frequently either a mediocre offspring or none at all. Unfortunately M. Renan's simile does not hold water. A man who dissipates the money accumulated by his ancestors impoverishes his family no doubt; but to say that a man of letters who commits his ideas to paper deprives his heirs of some tangible benefit is a near approach to nonsense. A flower is none the poorer for the perfume it sheds. The writer's view is that genius arises from the undue stimulation by means of nerve nutrition of certain functions of the brain at the expense of others, and that this departure from the normal course is liable through the principle of metamorphosis to lead to functional disorders among the blood relatives of the person affected. Of the morbid character of some forms of genius there is no doubt. ${ }^{1}$

That all-round natural ability which may be called talent falls into a different category. We are bound to admit that Nature is not averse to a general levelling up of ability. The Englishman has

I Moreau, La Psychologie Morbide; Radestock, Genie und Wahnsinn. 
a larger skull and a more highly developed brain than the Hottentot. The European child is born with a greater capacity for knowledge than the little African. It is even alleged by a French writer that the cranial capacity of the modern Parisians, according to his measurements of skulls, is thirty-five square centimetres greater than that of their ancestors of the twelfth century. ${ }^{1}$ As a process of elevation goes on in entire races, it is highly probable that within certain limits the crossing of talent would be advantageous. Without a rigorous adoption of the in-and-in system of breeding, with its multiform dangers, we must be prepared, however, to see all wide departures from the general rule of development repressed by the operation of natural laws. In heredity, tout se paye. Nature appears to have a horror of exceptions, and whether they occur in the direction of plus or minus, she takes immediate steps to restore the equilibrium. The mental peculiarities of an individual, whether good or bad, are not traceable in his offspring beyond the fourth or fifth generation. Every generation has its inequalities, which Nature steadily counteracts by the dual influence of the sexes.

1 Broca, Mémoire de la Société d'Anthropologie, 1873. 


\section{CHAPTEP XII}

BEAUTY AND THE ELECTIVE AFFINITIES

IN view of the great diversity existing among individuals of the human species, Nature has wisely provided us with a clue to the better types. Every man and woman prefers, more or less consciously, certain individuals of the opposite sex to certain others. Tastes may differ upon minor points of physique and character, but there are broad lines of preference common to entire races, and by this means a standard of beauty is arrived at. Here of course we touch upon the very keystone of the Darwinian theory, for beauty, practically considered, is nothing but fitness. That man or woman is beautiful who is best fitted for the conditions of life in which he or she is cast, and the preferences implanted in us are merely a device of Nature's for furthering the interests of the species by the elimination of the worst types and the reproduction of the best. 
With the question of beauty in general-beauty in art or beauty in the abstract-we are not here concerned, though it would no doubt be possible to sweep away many of the metaphysical subtleties of Plato by a breath of utilitarianism. The beautiful in nature is the suitable-that which is best adapted to a given purpose. When we look at the working of some complex machine performing its functions with precision and rapidity, we are filled with an admiration which is closely allied to a sense of the beautiful. But in art it is necessary to allow for the growth of what may be called formula- that is to say, an abstract notion of the beautiful, originally based upon fact, but subsequently divorced from it. Nothing is more common than the remark that the modern steamship is an unsightly object compared with the old sailing frigate. In the ship with its spreading sails the nice adaptation of means to an end is more obvious to the vulgar mind than it is in the case of a mass of floating iron moved by invisible machinery. Hence, long after the superiority of steam to sails has been established in practice, the sailing ship maintains its original position as a thing of beauty. A certain artistic formula grows up in connection with it, and to dissent from this is believed for a time to be 
evidence of bad taste. To the eye of the practical engineer, however, the steamship is more admirable than the old three-decker-in other words, it is more beautiful because he can see much in it that is not apparent to the popular understanding. The curve, again, is commonly spoken of as "the line of beauty." Why? Because in a great many positions-the arch of a bridge, for example-the curve is the more suitable line, and it becomes by this means the basis of an artistic formula.

In considering this subject we have to divest our minds of the idea that there is any such thing in the universe as intrinsic beauty. Beauty exists only in the eye of the admirer, who is unconsciously governed by a sense of utility or fitness from his own point of view. For this reason what is beautiful to one species is not necessarily so to another. Probably the belle of a London ballroom would leave but an indifferent impression upon the mind of a baboon. The adoption of utility as the basis of beauty prepares us for the curious fact that among mankind at large various standards of beauty prevail, according to climate, mode of life, and other circumstances. Among European races a clear skin and red cheeks are considered beautiful, because they are the ordinary signs 
of good health. Negroes, however, think differently. The tropical climate of Africa renders a black glossy skin desirable, and the darker a negro's complexion, therefore, the better-looking he is thought to be by his fellows. A pale negro is despised, because his pallor is unhealthy. The same influences prevail in men's conceptions of the supernatural. Contrary to European notions, negroes picture demons as white and celestial spirits as black. White is also the colour associated in their minds with sadness.

In savage races the jaws are strong and prominent. The savage uses his teeth for many purposes for which the European uses a tool. With his teeth he tears and grinds his coarse food, whereas a European softens his victuals by cooking, and then cuts them with a knife. To the savage, therefore, the small European jaw appears a deformity. Other characteristics of the savage are great width between the eyes and spreading nostrils, signifying aptitude for judging of the distance of objects and keenness of scent, qualities more essential to a barbarous than to a civilised life. Most races consider sound white teeth a point of beauty, the reason being that these are good for mastication. Among the Japanese and other 
Orientals the custom exists of staining the teeth black. This, however, is only a caprice of fashion, arising from the idea that it is not becoming to have one's teeth white "like those of a dog."

In physical beauty, as in art, formula plays its part. That is best in men's eyes which most resembles themselves. As a French writer has wittily observed, if the Triangles had a god, he would be three-sided. Every race fixes its standard of beauty in accordance with its own characteristics, which are apt to be pushed to an extreme; and we can always discover the prevalent conception of beauty in a given people by the efforts of individuals to beautify themselves. Thus, the Hottentots blacken their skins ; flat-nosed races flatten their noses to an unnatural degree by art; the Sioux brave having naturally little beard, makes a point of plucking his chin bare; the Chinese, who have small feet, try to make them still smaller; the Red Indian squaw reddens herself with coloured earths; the white woman whitens her skin and tints her lips and her cheeks. The ancient Greeks had a more open facial angle than their barbarous neighbours, and in their works of art they exaggerated that feature. It is in a similar spirit that Englishwomen, naturally tall and slender, subject them- 
selves to the tortures of tight-lacing, which among short squat races is unknown.

As the great function of women is to bear children, a full development of hips and bosom, meaning easy accouchements and plenty of nourishment for the offspring, is everywhere an accepted element of female beauty. At the same time excessive stoutness is abhorred, because it implies sterility, or at least a decline of activity or muscular power. The fashionable lady of London or Paris who artificially adds to her figure obeys an instinct that she would blush to acknowledge. She has probably never realised the meaning of the "padded hips and bosoms" that inspired Schopenhauer with one of his bitterest sarcasms at the expense of the sex. A red nose is fatal to a woman's charms, because it signifies some constitutional defect of a transmissible character, but a lover has no difficulty in reconciling himself to the temporary disfigurement of his mistress arising from illness or accident.

While some of the constituents of male and female beauty are necessarily unchanging, others are subject to modification by circumstances in a pretty marked degree, not merely as between one race and another, but among the members of a given race within a historical 
period. Among primitive peoples the best hunter or the best warrior is the most attractive man, inasmuch as he is the best able to hold his own and to provide for his family. Intellectual gifts are of small account in a savage community. The Government of Virginia in 1744 offered to educate some of the young men belonging to the Iroquois Indians, and a deputation of the tribe replied in the following terms: "We thank you for your kind attention. We have already had some experience of your education. Some of us whom you educated in all your science came back bad runners, ignorant of all woodcraft, unable to trap deer or to build a wigwam. Of what good was their education?" The Iroquois took a very sensible view of their position.

The ancient Greeks developed an art more congenial to savage notions than to the intellectuality of modern civilisation. The most cultured Athenian was but little removed in point of time from barbarism, and his instincts were strongly influenced by the conditions of savage life, as known to his immediate ancestors. Hence the tendency of the Greeks to extol the purely physical. "It was an artistic law in Greece that no victor in the games could have a portrait statue of himself set up unless he had been 
successful in all the five forms of contest, since anything short of success in all the five would leave open the possibility of certain parts of his body having been developed at the expense of others, owing to which it could not at the first glance present, as a perfect figure ought to present, that perfection of adaptability in all its parts to work harmoniously towards one end.... The grand characteristic of Greek art was the pursuit of beauty of form, to the neglect of all the varied beauty that may lie in moral expression." 1 Physical perfection was so important to the Greeks, indeed, that goodness and beauty in their tongue were expressed by the same word.

Are we nowadays prepared to accept the Greek estimate of beauty as absolutely true? Hardly. Art is still profoundly influenced by the Greek ideal; that is the inevitable effect of formula. But if a cultivated woman of the present day had to choose between a Greek Apollo and some less physically perfect but more intellectual-looking man, the god would probably be slighted. The truth is that manly beauty is no longer a matter of thew and sinew exclusively. Men do not now depend upon muscle even in the battlefield. Intellect is the ruling force of civilised society.

2 Iurray's History of Greek Sculpture. 
No doubt the savage respect for strength and courage is deeply engrained in our nature, so much so that few men, however intellectual, would refrain from showing off their physical prowess before ladies if the opportunity arose. Nor could the most intellectual woman deny the force of such a bid for her admiration.

But the man of strong mind nowadays possesses points of beauty - that is to say, of attractiveness wholly independent of physical form. How often do we hear a pretty woman say, "Mr. So-and-So is an ugly little man, but he is so nice." The speaker is conscious that her sentiment conflicts with the traditional idea of beauty, hence the apologetic form in which it is expressed. But what she says is the truth; instinctively she feels that in the battle of life as it has now to be waged her ugly but intellectual friend will prevail over a brainless Adonis. That fine physique is still an element of beauty it would be idle to deny; it is no longer, however, the only one. Men and women attract each other by their moral as well as their physical gifts.

Intimately associated with the question of beauty is that of the elective affinities. The attraction of physical excellence all can recognise, and heredity tells us that its importance to the species is great. 
But there is a moral as well as a physical side to heredity. Physical excellence we can see. How can we distinguish in a person of the opposite sex the moral qualities best fitted to make an advantageous blend with our own? The answer to this question, we imagine, is to be found in those manifestations of sympathy to which Goethe has given the name of Wahlverwandtschaften. It is customary to throw a little ridicule upon the term elective affinities, and to treat the sentiments so described as fanciful or unworthy of serious attention. The study of the subject has been left almost entirely to the poets and the novelists, who have acknowledged its importance without trying to explain it. Yet we have good reason to believe that the instinctive aversion or attraction felt by certain individuals for others is a fact of some importance in Nature's scheme. Let us see, first, what place the elective affinities have taken in literature. The most striking exposition of them is given by Goethe in his Wahlverwandtschaften, which is known to have been founded upon his own experience. Eduard and Cliarlotte had loved each other as boy and girl, but circumstances had parted them, and each had made a mariagc de convenance. Released from this by the 
death of their respective partners, the widower and the widow marry, in order to fulfil the dream of their youth. At the opening of the story they are happy enough, although a certain disparity in their natures prevents them from being entirely sympathetic. Theirs is such a union as occurs every day. Eduard has a bosom friend called the Captain whom he invites to come and live with him. This arrangement is at first opposed by Charlotte, who has a presentiment of evil, but she afterwards falls in with her husband's views, more especially as she desires that her adopted daughter Ottilie shall also become a member of the household. Thus four individuals are brought together under one roof-Eduard and Charlotte, who are husband and wife, and the Captain and Ottilie, who are unmarried. Conventional propriety would suggest an engagement between the Captain and Ottilie, but the elective affinities of the two couples rule otherwise. Eduard and Ottilie are violently drawn to each other, and so are the Captain and Charlotte, duty in each case being brought into conflict with passion. Goethe handles the subject with great moderation and delicacy. All the parties are restrained by social considerations, Eduard and Ottilie fretting under the tyranny of custom, and 
Charlotte and the Captain calmly sacrificing themselves to their sense of duty. Eduard wants a divorce, and Charlotte would gladly agree to such a step but for one unfortunate circumstance-she is pregnant for the first time. After the birth of the child matters go on as before, time exercising no healing effect upon these passion-racked natures until their bonds are broken by death.

In the trilogy of la femme, le mari, et l'amant, the same subject has been treated by many French writers from Corneille to George Sand. The common solution to the situation is the death of one of the parties. Whether it be the husband or the lover or the wife who disappears-and one of them is obviously de trop - is a matter depending mainly upon the temperament of the writer or the morals of his period. Perhaps the most instructive example for our present purpose is furnished by La Nouvelle Heloïse. Here the characters of the trilogy live side by side at the express desire of the husband. M. de Volmar, knowing the affection of his wife for Saint-Preux, proposes to overcome it by moral teaching, or rather to purify it of its grosser elements and transform it into a species of virtue. His efforts are vain of course. No more than Goethe does Rousseau 
succeed in finding a tenable situation for the two lovers instinctively drawn to each other, but separated by the barrier of a luckless marriage. Julie overcomes temptation up to a certain point, but just as the experiment in which she figures is about to fail she is conveniently engulfed in the waters of the Lake of Geneva.

With the morality of such questions we have nothing to do. Morality is a matter of social discipline; it is not an inherent principle in nature like the law of gravitation, but is a sort of understanding arrived at by nations or communities for the better regulation of their affairs. It would obviously be impossible for a man to commit any moral offence whatever if he happened to be the solitary inhabitant of a desert island, and where numbers of men are gathered together they have the right to agree among themselves as to what things may or may not be done-in other words, to erect a standard of morality adapted to their needs. Thus in an advanced condition of society thieving is a breach of a conventional regulation, but when two nations go to war they waive their understanding with each other upon this point, and the annexation by one of them of a slice of the other's territory 
is not regarded as theft. Writers who condemn marriage as an institution might with equal justice attack the law of property. Both are conventional ; both have been developed with a view to general convenience, whatever hardship they may inflict upon individuals. What we are now elucidating are certain aspects of the natural law, of which marriage is a conventional regulation.

That physical attractiveness in the parents is advantageous to the offspring admits of no doubt; and moral attractiveness, elective affinity, sympathy, or whatever we may call the ineffable sentiment that blends two natures into one, is plainly intended to fulfil a similar purpose. The evidence upon this point, it is true, is a little vague, chiefly because the experiment and observation from which it is derived have necessarily been limited. But as far as it goes it tells in favour of the theory which a sense of the perfection and completeness of Nature's plan suggests. Burdach confidently declares that love unions are more beneficial to the species than others. ${ }^{1} \mathrm{He}$ admits that illegitimate children do not exhibit any superiority as a rule. This is, however, to be accounted for by the greater anxiety, and even hardship,

I Burdach's Traité de Physiologie (translated from the German). 
that the mothers undergo. Moreover, we are hardly justified in assuming that illegitimate children are necessarily the offspring of love unions to a greater extent than others ; they result in the main from haphazard connexions lightly entered into. Alphonse de Candolle remarks that, "generally speaking, the rôle played by bastards in the princely families of Europe is remarkable when one considers their small number," I but history certainly does not furnish convincing evidence of the superiority of bastards, although Shakespeare appears to lend some countenance to that view. ${ }^{2}$ As regards the question of sympathy, irrespective of marriage, Burdach says: "When parents have an aversion for each other, their offspring is inferior; their children are not so intelligent or so apt" (leurs enfants sont moins vifs et moins dispos). To this opinion Lucas subscribes, ${ }^{3}$ remarking that forced unions tend to be less productive than voluntary ones. Sympathetic preferences and aversions are known to exist among the lower animals. Darwin gives some examples of these, ${ }^{4}$

1 Candolle's Histoire des Sciences et des Savants.

${ }^{2}$ King Lear, Act I. Scene ii.

${ }^{3}$ Lucas's Traité Philosophique et Physiologique de l'Hérédité Naturelle.

4 Darwin's Descent of Man. 
and Lucas quotes an amusing instance of a bull which, upon being brought into the presence of a particular cow, always made for the door of the cowhouse. Maudsley holds that the completest sympathy ought to exist between parents, seeing that "if there be indifference or repulsion, as happens sometimes where interest instead of affection makes a marriage, there cannot be that full and harmonious co-operation of all the conditions necessary to the best propagation." 1 In fact, that writer goes so far as to say that "insanity may be bred by unsuitable unions," among which he specifies the union of "essentially false and hypocritical natures."

Schopenhauer believed that physical qualities were transmitted by the father and intellect by the mother. This view of heredity has been proved to be erroneous, it being impossible to draw any such sharp line of demarcation between the respective functions of the parents. But the German philosopher clearly perceived the operation of the elective affinities, which he regarded as the efforts of the "genius of the species" (der Geist der Gattung) to promote the interests of the race at the cost, if need be, of the individual. ${ }^{2}$ For

1 Maudsley's Pathology of Mind.

2 Schopenhauer, Die Welt als Wille und Vorstellung. 
the sake of love-that is to say, of a union advantageous to the species-men, he pointed out, would sometimes sacrifice worldly position, friendship, life even. This is true, as is also probably his further reflexion that "the miserable condition of the majority of men, physically, morally, and intellectually, is due in some measure to the fact that marriages are not usually contracted by free choice, but through accidental circumstances." There is a host of proverbs in all languages advising people to study their pecuniary interests in marriage rather than their inclinations. "Marry in haste and repent at leisure," say the English. "Quien se casa por amores, ha de vivir con dolores," say the Spaniards. At the same time these counsels are manifestly antagonistic to our instincts. In a play the public are disgusted with the efforts of a father to marry his daughter to some wealthy suitor whom she detests, and are delighted when his scheme is defeated. In society too the man or woman who too obviously marries for money incurs a certain amount of odium. So far Schopenhauer's views are sound enough. When he tries to explain what influences determine the inclinations of the sexes, his misapprehension of the principles of heredity leads him astray. It is not the fact that snub noses seek to 
combine with aquiline, that tall men prefer short women, or that women of delicate sentiment are specially attracted by ignorant and boorish but vigorous men. Still more absurd, if possible, are Schopenhauer's theories as to fair people being a species of monstrosity, and having a strong desire to select dark partners, whereas dark people are seldom attracted by fair ones. The cultivation of excellence rather than the correction of existing defects appears to be Nature's aim. A good-looking man is not impelled to throw himself away upon an ugly woman; his inclination is to seek a partner as good or better than himself.

Regularity of feature and what is called expression, both undoubted elements of beauty, have probably some subtle relation to the moral qualities. We are certainly accustomed to judge of the character of men and women by their faces. One person is attracted by one style of features, another by another. If Nature's laws of combination and metamorphosis in heredity were thoroughly understood, which they are not at present, we should probably find that these instinctive preferences were a guide to the more satisfactory unions in point of moral disposition. The question of blondes and brunettes falls into the same 
category. Chemists tell us that the colouring of the hair and the skin depends upon the presence of certain pigments in those portions of the body of no importance to the individual. Considering that entire races are fair or dark, however, we can hardly accept the chemists' explanation as aught but a superficial onc. Complexion is governed fundamentally by climate, food, mode of life, and other physical conditions, all of which are bound to influence the moral character to some extent. When a man has a strong instinctive preference for a fair woman or a dark woman, therefore, we may assume that his moral qualities are such as will blend satisfactorily with those of the particular type of individual by whom he is attracted.

To the colour of the hair and eyes Beddoe attaches much importance as an element of race, the Celtic population of these islands being still distinguishable in that respect from their fellow-countrymen of Danish and Scandinavian blood. ${ }^{1}$ There is believed to have been into this country a very early influx of Iberian settlers, and the Celt is such a combination as might have resulted from the crossing of those dark Southern immigrants with long-faced,

2 Beddoe's Races of Britain. 
harsh-featured, red-haired native tribes. The prevailing Celtic colour, at all events, is dark brown, with extremes of red and black. On the other hand, the Danes and Scandinavians of the Eastern counties are fair and occasionally flaxen. In character the difference of race is hardly less marked, the Danish and Scandinavian population being plodding, industrious, and good-natured, and the Celtic fiery and impulsive, more quick than accurate in observation. It is no straining of probability, in these circumstances, to assume that complexion has something to do with our elective affinities. As Nature is an incorrigible leveller, there ought to be a tendency on the part of dark people to seek fair partners, and fair people dark ones. For this reason, combined with the greater facilities for communication now existing between one locality and another, the amount of very fair and very dark hair in this country, and probably in Europe generally, would seem to be decreasing, medium shades of brown taking its place.

The majority of marriages are contracted probably without much regard to the subtle preferences we have been discussing. Young people are thrown together by accident and marry as a matter of course. There is a general average of attractiveness in the sexes 
that serves to bring about this result, and its meaning is that any sort of union is better than none at all. Nature is content, like the master of a gaming-table, to establish one or two chances in her favour, trusting thereby to reap an ultimate advantage from the game, that ultimate advantage being the secret of evolution. Even where the elective affinities declare themselves, we must guard against supposing that they tend to the production of what we are accustomed to call superior types. As we have seen, certain forms of genius are closely allied to insanity, and the history of the world yields more than one example of a cultured and intellectual race succumbing in the battle of life. Goethe's long attachment to Christiane Vulpius was an exemplification of the elective affinities. From his relations with Frau von Stein we gather comparatively little instruction. Their attachment appears to have been a sympathetic one; but when it began Frau von Stein was a married woman of thirty-five with children, and Goethe a young man of twenty-seven. They saw each other constantly for nine years, at the end of which time Goethe went to Italy. On his return he became alive to the fact that Frau von Stein was forty-five, and the breach between them occurred 
soon after. It was at this period, when he was thirtyseven, that the poet met his fate. Christiane Vulpius has been described as a domestic servant. She was in reality a flower-girl, the daughter of a drunkard, whose vice she inherited, and had little or no education. But she exercised an infinitely greater influence over Goethe than any other woman, and it lasted for twenty-eight years, and till her death. Her charm, according to Lewes, consisted in "a quick mother-wit, a lively spirit, a loving heart, and great aptitude for domestic duties," qualities which in her youth were combined with "golden locks, laughing eyes, ruddy cheeks, kiss-provoking lips, and a small and gracefully rounded figure." In short, Christiane Vulpius was a "free, healthy specimen of nature, undistorted by artifice." ${ }^{1}$ So far well. But the single son whom she bore to Goethe proved to be less than a mediocrity. By the poet's friends he was contemptuously spoken of as "Der Sohn der Magd." Nature in this case would seem to have availed herself of the elective affinities in order to produce that levelling effect for which she so constantly strives.

It is probable that the elective affinities spring from an larmonious contrast of qualities, and not

${ }^{1}$ Lewes's Life of Goethe. 
from a similarity of disposition. The woman's nature ought to be the complement of the man's, and not its rival. She ought to supply those qualities in which he is lacking. The union of minds of a similar bent, as we have shown in the chapters upon Consanguinity and Blue Blood, is fraught with positive danger. What the offspring of a great poet and poetess would be we do not know by actual experiment, but analogous combinations are not of a favourable character. Maudsley cites the case of a married couple of marked business aptitudes. Both the man and woman were " extremely energetic, and by their joint exertions had built up from the humblest beginnings a large and lucrative business in London. The woman was of an anxious, inconstant, irritable temperament, always actively employed and eager in business; she died at a good age. The man was sanguine, choleric, and active, and died two years after her from apoplexy." People of this stamp are not instinctively drawn to each other ; they marry each other not for love but for business, and Nature takes care to punish their disregard of her laws. In the instance above quoted there was a family of ten. Writing of the case as one actually under his observation, Maudsley says : "Four grown-up members of the family are already 
insane, and more will probably become so." ${ }^{1}$ We may conclude that had the couple in question married what is commonly called their "opposites "- that is to say, had they given freer play to their elective affinities-they would each have produced a healthy offspring.

Love-making, as Schopenhauer has pointed out, is mixed up with a deal of romantic nonsense, which disguises from both parties the real question at issue. Probably the dialogue of the most romantic pair of lovers in the world, if divested of its flummery, would take the following shape:-

He: I want to be the father of a fine boy or girl, and I think you can help me. Will you?

She: With all my heart.

$H e$ : You are plump and well-proportioned.

She: You have fine stature and muscular force.

$\mathrm{He}$ : You are healthy.

She: So are you.

$H e$ : You are fair, gentle, and trusting.

She: You are dark, energetic, and firm.

He: Your features show nobility and pride.

She: Yours, courage and goodness.

$H e$ : You liave delicacy of sentiment and virtue.

1 Maudsley's Pathology of Mind. 
She: You, perception and honour.

$\mathrm{He}$ : You are very intelligent.

She: You are very clever.

$\mathrm{He}$ : All these qualities combined will make a very fine boy or girl, and that is why I prefer you to any other woman.

She: And that is precisely why I prefer you to any other man. 1

${ }^{1}$ The conversation of Schopenhauer's Daphnis and Chlöe, rewritten and brought into harmony with the principles of heredity and elective affinity, as set forth in the present volume. 


\section{CHAPTER XIII}

\section{POLYGAMY}

IT is clear from our examination of the principles of heredity that the society in which the female sex is systematically downtrodden or enslaved pursues a suicidal course, and that the secret of human progress lies in the freest recognition of the rights of the individual woman. If there is one lesson more forcibly taught by heredity than another, it is that the interests of the sexes are absolutely solidaire. Treated as serfs, as mere instruments for the gratification of passion, denied education and the right of choosing their consorts, women exact a terrible penalty from the ensuing generations of men. What is the experience of the world in this respect? We shall see.

Polygamy is the practice of the majority of the human race. It is the keystone of the great religious 
system founded by Mahomet; Hinduism and Buddhism sanction it; barbarous races in all quarters of the globe know no other law. At a modest estimate, $500,000,000$ or two-thirds of mankind are polygamous. The forms of polygamy vary, but they have this in common, that the woman is treated as the inferior animal, and is allowed little or no voice in the disposal of her person. Schopenhauer declared polygamy to be the natural and proper condition of mankind. Regarding women as fit only to be housekeepers and concubines, he reserved his bitterest sarcasms for the European "lady"-that "monstrous product," as he called her, "of Germano-Christian stupidity, with her ridiculous claims to respect and veneration." ' But the German philosopher, while possessing a clear insight into many of the problems of life, was hopelessly warped and prejudiced in his views of womankind, and his admiration of polygamy was certainly not based upon truth. It is a matter of common remark that the Oriental harem has at least the advantage of abolishing prostitution. That is so. In polygamous countries every woman finds a home and a master. But this advantage, if it be

1 Chapter "Ueber die Weiber" in Die Welt als Wille und Vor. stellung. 
one, is but a small set-off to the soul-deadening effects of a system which degrades not one class of women, but the whole sex, and which reacts with fatal effect upon their enslavers.

Mahomedanism has probably done more than any other religion to retard the progress of mankind ; and that because to polygamy it has added the no less pernicious institution of the veil. In the 24th Sura of the Koran women are enjoined to conceal their charms from all men save their husbands, fathers, sons, nephews, and slaves. No injunction could be more innocent in appearance than this. Yet throughout a quarter of the population of the globe its effect has been to prevent the growth of all that we know by the name of home-life, to destroy the germ of all art, all poetry, all romance, nay, all literature beyond the most primitive. Except among the lowest classes, no Mahomedan sees a woman unveiled outside his harem, not even the wife of his dearest friend, the nearest approach to domestic intercourse of the European kind being that a guest should be regaled at dinner with a dish prepared by the wife of his host with her own hands. It follows that marriages are made without any regard to the disposition of the parties. They are arranged by go-betweens, the 
cardinal point of the negotiation being the dowry. If this is settled, the rest follows as a matter of course. Parents give their daughters in marriage without their consent, and the "husband can scarcely ever obtain even a surreptitious glance at the features of his bride until he finds her in his absolute possession." Divorce being optional, the dowry is the Moslem wife's sole guarantee of the stability of the marriage, since she is entitled to take away with her from her husband's house whatever property she may have brought into it. A widow or a divorced woman enters into a new engagement without any ceremony at all.

For economical reasons a man may not be able to keep more than one wife, but the laxity of the relation is such that he can change her almost every month. It is a common experience in Mahomedan countries to meet men who in the course of ten years have married as many as twenty or thirty women, and women not far advanced in life who have been wives to a dozen or more men successively. ${ }^{2}$ The lower classes necessarily dispense with many of the formalities observed by their betters; but among them also marriages are viewed as a matter of business, good-looking girls 
being sold by their parents to some wealthy functionary.

And the most shocking feature of Mahomedanism is that the customs which have shackled a large section of the human race for so many centuries appear to have had their origin in the personal necessities of the so-called successor of Christ. Polygamy is the Mahomedan law, because Mahomet allowed himself the luxury of ten wives. The faithful are restricted to four, but this restriction is tempered by a liberal allowance of concubines. As to the veil, that was suggested by an incident in Mahomet's own experience. While he was visiting Zeid, his adopted son, Zeid's wife, Zeinah, started up in confusion to array herself decently, but the accidental revelation of her charms made a profound impression upon the prophet. Sura xxiv. was promulgated soon afterwards. But the prophet was unable to banish from his mind the thought of Zeinah's beauty. He wished to marry her, and Zeid was not unwilling that he should, but the relationship of the two men, as father and son by adoption, rendered the transaction scandalous. The difficulty was solved by a special revelation, set forth in Sura xxxiii., which not only sanctioned the prophet's 
marriage with Zeinah, but reproved him for having hesitated to add her to the number of his wives. By the same Sura various other of Mahomet's domestic troubles were allayed. His partiality for Ayesha provoked discontent in his harem until it was revealed to him as the divine will that a husband was dispensed from paying an equal amount of attention to all his wives. He himself, on the other hand, was somewhat inclined to jealousy. Accordingly his wives, some of whom were young and beautiful, were invested with a special sanctity, and a divine interdict was set upon their marrying again. ${ }^{1} \quad$ It is strange to reflect how greatly the world has suffered from the caprices, the fears, and the fancies of one selfindulgent old man.

Hindu marriage, which affects the welfare of some hundred and fifty millions of the human race, is another example of the perversion of natural laws by religious fanaticism or superstition. Based upon the sacred books of Manu, which date many centuries before Christ, Hindu marriage is distinguished by the multiplicity of wives or concubines, the betrothal of mere children, and the indissolubility of the nuptial tie, however contracted. Religious authorities declare

1 Sir W. Muir's Mahomet and Islam. 
that a girl must be given in marriage before the age of puberty, and the conventional shame attaching to a family in which this ordinance has been neglected makes every father anxious to dispose of his daughter at a very early age. Ordinarily the lowest age for marriage is eight years, but Manu allows a girl to be married earlier if a suitable husband can be found, ${ }^{1}$ and the contract is not dissolved even by the husband's death. Formerly widows were expected to sacrifice themselves upon the funeral pyre of their husbands, but in 1829 this practice was abolished. Terrible as it was, the law of suttee was perhaps more merciful to the victim than the social convention which has taken its place. For the Hindu widow, even if she be of tender years, is now an outcast from society. Some thirty years ago the scandal of child-widows in India induced the English Government to pass a law allowing them to remarry, but the Act, being opposed to religious sentiment, has practically remained a dead letter, ${ }^{2}$ and the Hindu widow is condemned to lifelong degradation and wretchedness. Nor may any woman hope to evade her responsibilities by remaining single. Besides being betrothed before she is of

1 Banerjee's Hindu Law of Marriage.

${ }^{2}$ Ibid. 
an age to understand the ceremony, the female Hindu is driven into marriage by religious cousiderations, the ceremony being regarded as a sacrament essential to her entrance into that final state of beatitude which is the hope of every follower of Brama. Unlike the Mahomedans, with whom marriage is merely a temporary arrangement, the Hindus have contrived an elaborate series of nuptial rites, which are to be explained no doubt by the terribly serious nature of the contract from the point of view of Hindu law and custom. But while the Mahomedan woman may be, and sometimes is, put to death for adultery, the Hindu wife who has been faithless is merely deserted. Within the sphere of English influence, at all events, she is not liable to further punishment. No other course could be sanctioned by English opinion. Married while children, Hindu wives are often neglected while still young; at the best they share the attentions of a husband with several rivals. To punish their inconstancy while the husband is allowed to fill his zenana with women would, according to Western notions, be a monstrous injustice.

Among the Mongolians, who form the third great section of the polygamous races of the world, marriage is conducted pretty much upon the Mahomedan plan- 
that is to say, matches are made by go-betweens, and the nuptial ceremony has no sacred or binding character. In China women have no legal status. They are the absolute slaves first of their fathers and secondly of their husbands; the father may sell his daughter and the husband his wife, and a widow is the property of her deceased husband's relations, who generally dispose of her to the highest bidder. ${ }^{1}$ Concubines live under the same roof as the wife. They are bought and sold without any formalities, and are often the first sacrifice made by a Chinaman who has to reduce his establishment. Marriages are arranged without any selection being exercised by either of the parties; and it is understood that, however ugly or deformed a bride may prove to be, she cannot be rejected by the husband after she has unveiled herself in his presence.

In a recently published work in French, ${ }^{2}$ General Tcheng-ki-Tong, military attaché to the Chinese Legation in Paris, denies that his countrymen are polygamous, but as he admits that the Chinese concubine enjoys a legal status, his argument appears to be somewhat sophistical. The wife is obliged to accept the

1 Cooper's Travels of a Pioncer of Commeree.

2 Le Theatre des Chinois, by General Tcheng-ki-Tong. 
concubine openly, and the manner of their introduction to each other is regulated by custom. Upon entering her new abode the concubine is expected to show her respect for the wife by four salutations. The wife receives the first salutation seated, at the second she rises, and the third and fourth she returns. If these formalities are disregarded on either side domestic trouble ensues, and the plight in which the unfortunate husband then finds himself is a frequent theme of satire in Chinese comedy. Among the Buddhists, as among the Mahomedans, a woman's property has a steadying effect upon her matrimonial fortunes, but her personal claims to consideration are nowhere recognised.

Throughout the East it may be said, generally, that the instinct of selection, and many concurrent sentiments which tend to the development of higher social states out of lower ones, are systematically repressed or violated. We know by familiar experience that every breach of Nature's rules involves a penalty. The man who disregards the principles of health drags out a feeble and unprofitable existence, if he does not promptly pay for his temerity with his life. Nations are subject to the same law, and in the virtual subordination of the teeming millions of Asia 
to a handful of vigorous Europeans we see the penalty that the "changeless East" is paying for its many centuries of misguided fanaticism and mistaken self-indulgence. What have the vast populations of the East contributed to literature, art, or science, for the past thousand years? Practically nothing. It may be said that these things are not progress, and perhaps they are not-the question cannot be settled by puny mortals who know nothing of the true destinies of the human race or the final goal to which evolution leads. But if we test the social methods of the East and the West by the sum of their contribution to human happiness, the balance, we imagine, turns in our favour. And such advantages as peoples of the European stock have won over the rest of the world in all that distinguishes civilisation from barbarism may fairly be ascribed to monogamy. For this is not only the inspiration of love, and consequently of all the refining arts, but by the operation of selection and heredity it is the source of cumulative knowledge, or rather of cumulative capacity, in the races brought under its influence. The well-born Turk or Persian, for example, is the son of a mother who is wholly destitute of intellectual culture, and who passes her time lounging in the bath and gossip- 
ing with her fellow-slaves. What can be the results of heredity in such a case? What intellectual advancement is possible among a people each successive generation of whom is dragged down to the level of barbarism by maternal influence?

There is no better illustration of the sterilising effects of polygamy upon the human mind than the condition of the literature of polygamous races. Where the passion of love in the European sense of the word is unknown, poetry and fiction may be said to be in their infancy. This is eminently so in Turkey and Persia; and in these countries, moreover, the stage-another important vehicle of sentiment-has hardly risen above the level of our Punch and Judy show. Turkish and Persian plays consist for the most part of illustrations of certain stereotyped religious subjects or exhibitions of the merest buffoonery, sometimes of a disgusting character. Under the influence of French and Italian models, a more vital species of performance has recently been springing up, but the motives of this nascent Mahomedan drama, judging by some samples recently published by a French writer, M. Alphonse Cillière, are still in the embryo state. The most interesting of M. Cillière's translations is a study of harem jealousy-a 
very different sentiment of course from that which occasionally agitates the bosom of the European wife. Ziba-Khanoum, the heroine of the Turkish play, has no desire to monopolise her lord's attentions; she merely resents the fact that Cho' Le-Kanoum has had a prettier dress than herself, and is the recipient of one or two other special favours.

Chinese sentiment is comparatively liberal. Even to a Chinaman, however, the part assigned to love in European novels and plays appears eminently absurd. ${ }^{1}$ Filial piety is in China the great dramatic motive, and a secondary one is literary ambition, or the struggle to win a prize in the numerous scholastic competitions established throughout the Empire. The "juvenile lead" or the "walking gentleman" of the Chinese stage is usually, therefore, a dutiful son or a successful student. The philosophy of Confucius

1 General Tcheng-ki-Tong in his Theatre des Chinois romarks that the Chinese stage is very far from attaching the same importance to love as the French. "L'amour tourmenté, tyranisé," he observes, "paraîtrait à nos yeux une exaggération. Ces tempêtes violentes qui s'élevent dans le cœur et ne laissent après elles que des lendemains sans espoir, sont all-dessus de notre imagination et ne pourraient, dans tous les cas, qu'être très-rares dans notre société où l'antorité paternelle est absolue. Il est donc aisé de com. prendre que les grands drames de l'amour n'auraient, devant notre public, ancune chance de succès." 
continues to be the basis of all Chinese culture, while the modern literature of the Celestials consists mainly of endless prefaces to and comments upon the works of ancient writers.

Although persistently thwarted by human caprice, Nature never ceases to strive for the accomplishment of her aims, and we can perceive a tendency in the customs of Mahomedanism to break down under the strain she imposes. Thus the marriage of first cousins is looked upon in all Mahomedan countries with special favour. In noting this fact Lane remarks that such unions are generally lasting, and that they have in most cases a true basis of affection, owing to the parties laving been acquainted with each other in early life. Can the favour with which these matches are viewed be due to a public consciousness of their propriety in point of mutual affection? Possibly. In that case the awakening sense of the superiority of a love-match to the ordinary Mahomedan marriage may be regarded as the thin end of the wedge. There is certainly little doubt as to the gradual subversion of that curse of Mahomedan life-the veil. In Egypt, according to Lane, "motives of coquetry will frequently induce a woman to expose her face to a man when she thinks 
she may appear to do so unintentionally." "In Persia a glimpse of a lady's face is seldom to be got, save by stratagem, or by what is considered an immodest act on her part, the raising of a corner of the veil by the lady herself; but the Persian belle yet contrives to find a way of rewarding her admirer with a glance." I In Turkey the difficulty presented by the veil has been ingeniously turned. "So coquettishly is the transparent muslin folded over the nose and mouth that the delicate cloud seems but to heighten each charm. Far, very far is it from hiding the wearer's features from the profaning eye of man." 2 It is by such devices that Nature seeks to regain her ravished rights. Failing the recuperative power required for its revival, an ailing race succumbs in time to a stronger competitor; the fittest, in a word, survives. On the face of the earth, as on a scroll, how many records, lost to history, may have been written and erased by successive races or civilisations?

Mormonism, free love, and other new-fangled substitutes for monogamy adopted in America are experiments bound in natural course to fail, because they conflict with instincts which, having grown up

1 Wills's Persia as it is.

2 Mrs. Harvey's Turkish Harems and Circassian Homes. 
during many generations of European or American life, cannot be eradicated in a day. Not one of the polygamous societies of the West has succeeded in establishing itself upon a permanent basis. In the working of the system of "complex marriage," as practised at Oneida Creek, we find a remarkable illustration of the force of inherited sentiment, and the virtual failure of Father Noyes's community may be regarded as typical of the fate of all such experiments unless they happen to be backed up by religious faith of a powerful and enduring character. Complex marriage is a euphemism for free love, its principle being that within the limits of the community any men or women may cohabit by natural consent, the children being reared in a common nursery.

Considering that Father Noyes's adherents are without exception of European blood, we should expect the growth of exclusive attachments to be the bane of the free love system, and in point of fact that has proved to be the case. The members of the Oneida Creek community find in practice, says Nordhoff, " a strong tendency towards what they call selfish love-that is to say, the attachment of two persons to each other, and their desire to be true to each other-and there are here and there in their publica- 
tions signs that there has been suffering among their young people on this account." ${ }^{1}$ The same writer reports a significant speech delivered by Father Noyes at a meeting of the community held for the purpose of censuring the backsliding of a member. "Our brother," said Noyes, "has fallen under the too common temptation of selfish love, and a desire to wait upon and cultivate an exclusive intimacy with the woman who is to bear a child through him. This is an insidious temptation very apt to attack people under such circumstances, but it must nevertheless be struggled against." ${ }^{2}$ Father Noyes was mistaken in supposing that his theories of marriage could be successfully enforced by argument. A preference for free love on the part of both sexes could only be established by heredity- "fixed," that is to say, in the course of many generations-and when this result had been achieved by artificial means, the community left to its own devices would slowly revert to monogamy, which is obviously intended to be the ultimate condition of the race, or an important factor, at all events, in psychological evolution.

1 Nordhoff's Communistic Societies in the Unitcd States.

2 Ibid. 


\section{CHAPTER XIV}

\section{THE FAMILY INSTINCTS}

THE course of our inquiry into the relations of the sexes from the earliest times will have prepared the reader for a refutation of the commonly accepted axiom that human nature is the same in all ages and all over the world. No fallacy could be greater or, indeed, more self-evident than this ; and the modern poet, dramatist, or novelist who acted upon it,-who neglected the spirit of his own age in order to follow classical models,-would find himself hopelessly at variance with the sentiment of his contemporaries. In the relations of members of a family towards each other, more especially those of parents towards children, the same evolutionary process goes on that we have traced in regard to matrimony. The stern Roman father who exercised over his children the power of life and death has been slowly transformed 
by circumstances into the meek, submissive, policeridden householder and ratepayer, who, if he dared to lift his hand to a disobedient son, would be punished by the tribunals. Simultaneously with the emancipation of women there has come about the disintegration of the family. In France and the Latin countries generally, parental authority being intimately bound up with the legal code, continues to be more or less respected; among the Anglo-Saxon communities it has become merely nominal. Englishmen are apt to be amused at the reverence shown in French drama and literature to the sacred names of "father" and "mother." But in France the manifestation of filial respect is as real as that of the contrary sentiment in this country, where, on the stage at least, a man who wept at partiug from his parents, or who even consulted them about his love affairs, would be laughed at.

Broadly speaking, the more highly developed our social relations become, the more is the individual citizen subordinated to the community, and the smaller is his power of initiative or right of private judgment. The resident in a great town may have his own ideas of adorning his dwelling or ministering to his comfort; but if these conflict with the interests of the community, the State steps in 
and restrains him from carrying out his caprice. In accordance with this principle, the rights of a father or mother, sacred in the eyes of the ancients, have been seriously encroached upon by the State, which requires that a parent shall train his children in conformity not with his own ideas, but with those of the community; and, as in the case of marriage customs, the modifications of sentiment involved tend to become acceptable. When a new law is passed, like that of compulsory vaccination, it may for a time be felt as a hardship by individuals, but in the end the people adapt themselves to their new conditions, and men accept as natural and proper what their fathers may have regarded as an exercise of tyranny.

We have more than once turned to the drama as an index of the sentiment of a particular period. Historians, who concern themselves more with names and dates than with the spirit of the age they deal with, leave us no other resource. Perhaps no better guide to the truth could be desired. There are always two kinds of sentiment reflected in the drama and the literature generally of a people; there are those that a man finds in his heart and those that he finds in his imagination. The latter serve to explain and 
to complete the former. The characters conceived by the poet or the dramatist are to some extent ideal of course, but unless they stand in intimate relation to the heart and the imagination of the author's contemporaries they fail to produce the requisite impression of sincerity and truth. Judged by the literary standard, the family instincts of different ages and peoples, from the dawn of civilisation in Greece to the present day, are precisely what, having regard to the evolution of society, we should expect them to be. From having unlimited confidence in his own authority, which in his eyes was based alike upon nature, law, and custom, the father has become timid, vacillating, and weak. He no longer commands; he entreats. For his loss of dignity and authority he endeavours to compensate by a display of tenderness. That the part thus played by the father in society has degenerated, we do not say; but it has changed, and is changing, and the fact is one with which the sociologist is bound to reckon.

As an example of the different ideas entertained of the authority of parents at different periods, let the reader compare for a moment the Edipus of Sophocles with the King Lear of Shakespeare. Both poets treat of the ingratitude of children, but they do 
so in a widely different spirit. Sophocles vindicates the sanctity of parental authority by the most impressive means. The vengeance of CEdipus towards his sons is implacable. When Polynices implores forgiveness, Edipus refuses to answer him, because it would be a profanation of a father's lips to hold communion with an ungrateful son. Entreated by his host to speak to Polynices, Edipus, in recognition of the sacred law of hospitality, consents at last to break silence, but only to pronounce a curse upon the offender. The justice of the gods forbids any exercise of his clemency, because it is necessary that the outrage offered to the majesty of the father should be avenged. Such was the early Greek view of the parental relationship. Lear's personality has few of the solemn attributes of his Athenian prototype. If he has been driven forth by his two undutiful daughters, Regan and Gonerill, the fault is his own; he has despised the counsels of his faithful Kent and mistaken the true affection of his other daughter Cordelia, and the thought of retribution for his wrongs is lost in the pathos of the ending to his poor misguided life.

As the ancient civilisations lasted many centuries, they found time to work out some of the moditica- 
tions of sentiment which inevitably occur in a society passing from the rude barbaric to the highly cultured stage. Euripides is less stern and severe in his views than the earlier poets. His heroes preach clemency and pardon. Menander and the writers of his school are almost as indulgent as the moderns in respect of the relations of father and son. "A good father," says Menander, "ought not to be angry with his own flesh and blood. If he would have his son watch over him in his old age, let him give the youth what he wants." In Rome the same spirit of moderation was developed from the austere customs of the early Republic, the father gradually relinquishing what may be called the functions of the magistrate in order to take up those of the parent as the word is now understood. The change is clearly indicated in one of the dramas of Terence. A father is resolved to be severe with his son, according to the ancient custom, and by his rigorous discipline he drives the young man into foreign service. Thenceforward he knows no peace of mind. He is given up to remorse, and lives a life of hardship in order to punish himself for his cruelty to his son, whom he ultimately welcomes home with open arms. In the same play the paternal authority is attacked from 
another side. Father No. 2 preaches the maxims of the old school. His son argues against him. "Fathers," says the latter, "are unjust; they would have their sons be as old as themselves; they make no allowance for the passions of youth. If I had a son I would be indulgent to him; he should be as ready to confess his faults to me as I should be to forgive them." Plautus also reflects the growing relaxation of paterual authority. In the latter days of the Empire nothing of the old severity of manners remained.

To a great extent the Christian communities of Europe have solved the problem of domestic discipline de novo. They have long been drifting towards a subversion of parental authority altogether, and, in this country at least, the goal has almost been reached. In France, thanks to the Code Napoléon, parents still retain a show of authority; but although the dramatists and novelists treat the title of father with a degree of respect unknown to the Anglo-Saxon races, they do not hesitate, on occasion, to exhibit the paternal relationship in a Iudicrous light. ${ }^{1}$ The change has been in progress since the time of

1 See, for example, that admirable comedy by Augier and Sandeau, Le Gendre de Monsieur Poirier. 
Molière. In the last century Rousseau and other writers lifted up their voices against the so-called degradation of paternity, but without effect, the evolution of sentiment being determined by subtle causes which a literary critic can hardly hope to combat. There is no need to study the stage at the present time with regard to the state of the family instincts; but in order to follow out consistently our plan of observation, we may remark that the student of sociology who cares to consult the contemporary drama will find the father occupying there a very uncertain position, being only saved from ridicule, as a rule, by his affection for his children-an affection wholly divorced from a sense of his own authority or personal dignity. In a word, the paternal character among modern Englishmen may be said to have lost all its majesty, and to have become trivial, or at least politically unimportant. The maternal relationship has been of necessity more stable than the paternal from the earliest times, but even that appears to be losing ground, sons and daughters of the AngloSaxon race being careful nowadays to emancipate themselves, and what is more important, being allowed to do so, from almost all parental restraint. In a still greater degree than it has yet done, 
parental authority is likely to pass from the individual to the State. We cannot affect to view the process with uneasiness. All the great social problems now claiming attention-problems of disease, poverty, education, and even heredity - are only to be solved by such wholesale measures as the State can undertake. The family is too small a unit for the purposes of scientific experiment; the head of the family must subordinate himself to the head of the community. In the ancient civilisations parental authority decayed before anything was ready to take its place. The society of the present day is more happily circumstanced, and as the logical result of the social tendencies above traced we may confidently look forward to an application of the principles of social science upon a scale hitherto unknown. 


\section{CHAPTER XV}

THE FUTURE OF SOCIETY

MaNy important truths are forced upon us by a consideration of the foregoing facts-truths which sooner or later cannot fail to affect our social life-and a rapid review of these may fittingly bring our task to a close. The first, and perhaps the greatest lesson of heredity is that the individual man is much less the arbiter of his own destinies than his pride would have him believe. Born to a heritage of physical and mental capacity, of instincts and sentiments that he has the power to alter only in a limited degree, he may be said to be the creature of circumstances, the sport of fate. He is a waif and stray upon the ocean of life, driven hither and thither by currents over which he has no control, and whose existence for the most part he does not even suspect. All philosophical and religious systems are faulty which attribute 
to the individual a full responsibility for his physical or moral condition. No man by taking thought can add a cubit to his stature. No man by taking thought can make himself wise or witty or virtuous; he may do something for the improvement of his character, as by judicious diet and exercise he may add to his height or weight, but the main lines of his moral and physique are determined for him. The results of Nature's care are shown in the moulding of the species ; the individual is the subject of countless experiments, successful or unsuccessful, all directed to the great end of the discovery of the fittest. Life may be said to be ever striving to assume the most suitable form; it gropes its way as it goes, and avails itself of all the aids to progress it can find upon the route to its unknown goal.

In an interesting speculation upon the future status of women, Herbert Spencer assumes that the legal bond of marriage will cease to be tolerated unless it happens to coexist with a bond of affection between the parties. ${ }^{1}$ We do not see in the existing condition

1 "As monogamy is likely to be raised in character by public sentiment requiring that the legal bond shall not be entered into unless it represents the natural bond, so perhaps it may be that the maintenance of the legal bond will come to be held improper if the natural bond ceases. Largely increased facilities for divorce point 
of society, or in the past experience of the race, any sufficient warrant for this view. The welfare of the children, not the convenience of parents, is most likely to determine the course of domestic evolution. Mainly for the children's sake was the legal bond of wedlock instituted; for their sake it will probably be maintained, during the whole of that phase of human life, at all events, with which we are acquainted. It is true that the State is usurping parental functions with regard to the education, the hours of labour of the young, and like matters; but the establishment of a great State nursery, which would inevitably attend the abolition of the legal responsibility of parents, still lies far beyond the range of practical legislation. However organised, it is doubtful whether a common nursery would be a boon to its inmates. A common nursery was one of the features of the free love

to the probability that whereas, while permanent monogamy was being evolved, the union by law (originally an act of purchase) was regarded as an essential part of marriage, and the union by affection non-essential, and whereas at present the union by law is thought to be the more important, and the union by affection the less important, there will come a time when a union by affection will be held to be of primary moment, and a union by law as of secondary moment; whence reprobation of marital relations in which the union by affection has dissolved."-Herbert Spencer's Principles of Sociology. 
community at Oneida Creek. Children after being weaned were affiliated to the community, and Nordhoff says they looked healthy enough, but that they lacked buoyancy and gladness, as though they missed the exclusive love of a father and mother. In the state of society conceived by Herbert Spencer the convenience of individuals would be consulted at the expense of the race, whereas in evolution the contrary principle prevails; it is the individual who is sacrificed to the community.

Of the latter truth we have an example in the matter of large families and over-population. Lord Kames, a very shrewd thinker in his day, said he was tempted to blame Providence for developing appetite in the youth of both sexes long before they were able to maintain a family. We can now perceive, however, that Providence knows its own business best, and that the efforts of Malthus and other philanthropists to keep down population are really directed against the most powerful of the civilising agencies. Under stress of over-population, the predatory race develops into the agricultural, and the agricultural into the manufacturing; the same spur of necessity impels us to go on improving the arts and appliances of civilised life. That the number of mouths to be fed in England 
should be increasing at the rate of 1000 a day is a substantial guarantee that our civilisation cannot rest upon its oars, but must keep advancing. Indirectly the poor man who brings forth children he cannot feed is a public benefactor; he renders the struggle for life more acute, and by that means stimulates the energies of his race. In throwing his family upon the world in the vague hope that they will somehow be provided for, or without any reflection at all, ho unconsciously obeys the dictates of the Geist der Gattung of Schopenhauer-the Genius of the Species, which is constantly sacrificing the individual to its higher ends.

Modern philanthropy strives by all the means in its power to defeat the natural laws of progress. This it does by placing the interests of the individual above those of the species. In social life it succours the infirm and the unfit, and encourages them to multiply their kind. In politics it labours to ward off or to mitigate the hardships produced by over-populationto retard, therefore, the great natural crises by which peoples and nations are regenerated. Had philanthropy of the modern stamp existed as a force in central and southern Asia five or ten thousand years ago, it would probably have exerted itself to prevent 
the great westward flow of the Aryan race. Both politicians and philanthropists will probably be induced to modify their aims and methods when the principles of evolution are fully understood.

As to marriage, there is no evidence that mere affection can ever be a sufficiently enduring bond between the sexes to safeguard the interests of the offspring. Although in exceptional cases the play of the elective affinities may be trusted to bring about lasting unions, the general attraction of the sexes for each other is such that unions of affection will always be liable to be lightly formed and as lightly broken. The qualities that attract a man or a woman in one of the opposite sex are frequently such as exist in a thousand men or women in the same community. What guarantee of stability, then, would an ordinary love union possess? If the legal bond ever became subordinate to or dependent upon the bond of affection, we should practically be reverting to the primitive conditions of communal marriage from which our ancestors long ago emerged.

But if monogamy is likely to remain unchanged in its main features, so long as the State is unprepared to take parental charge of the children born within its borders, there are many minor modifications of the 
system which public opinion, based upon a knowledge of heredity, may be trusted to bring about. The general recognition of the moral side of heredity will tend to revolutionise our time-honoured method of match-making in which the moral fitness of the parties is never taken into account. Physical fitness is so far considered that the union of a young girl with an old man, or a young man with an old woman, for the sake of wealth or worldly position, is generally condemned. The deformity of one of the parties is also deemed to be a bar to marriage. But the existence in a given family of insanity, drunkenness, or vicious propensities of any sort, is not yet thought to be a disqualification to any of the marriageable members of that family, provided they appear to be free from the congenital taint. No heed is given to the possibility of the disease existing in those persons in a latent form, to be developed by them in after life or transmitted to their children in a simple or a metamorphosed state. To this fertile source of misery and suffering we may assume the society of the future will open its eyes with a view to the establishment of a system of moral as well as physical selection.

There has frequently been acted in London during the past twenty years a comedy in which the prin- 
ciples both of moral and physical heredity, curiously enough, are unconsciously outraged by the author. ${ }^{1}$ A vain, pompous, selfish, hypocritical, unscrupulous father has a couple of pretty daughters engaged to two young men, one of whom has been blind from birth. The author seeks to enlist our sympathies with his matrimonial scheme, and, so far as the unreflecting portion of the public is concerned, succeeds. Yet the two girls, charming though they be in appearance, are presumably by hereditary influence, that is to say, as the daughters of such a father, moral lepers, born with a predisposition to vice, while one of them mating with a blind man may be expected to produce physically imperfect children! To those acquainted with the operation of heredity the spectacle thus presented is as painful as would be that of the beautiful and virtuous heroine of a play, being forced to wed some old, deformed, and miserly suitor. The performance of the comedy in question passes without protest from the public of the present day. If we mistake not, a time will come when such a story will be utterly repugnant to popular sentiment.

How the difficulties connected with moral heredity

1 The Two Roses, by James Albery. 
may be solved in the future relations of the sexes we can only surmise. As civilisation tends to foster in us a faculty of self-regulation,- - the subordination of private to public interests,-it may become obligatory upon families or communities to keep exact genealogical records, showing the moral pedigree of every one of their members. Under this system, when a marriage was proposed the moral pedigrees of the parties would be consulted, and their fitness or unfitness for each other ascertained. Supposing both to have a particular form of congenital weakness likely to be fostered in their offspring, the marriage would be pronounced inexpedient, and public opinion would uphold the ruling. And while unions likely to breed mental or physical disease would be rendered difficult, if not impossible, by the force of public sentiment, those favourable to the species would be encouraged. It would not follow that any great number of people would be disqualified for marriage altogether, although no doubt this would happen in certain cases. They would be compelled to choose their partners upon rational principles, every tendency to degeneration being as far as possible counteracted.

The known daugers of consanguinity have already 
created in the public mind an instinctive aversion to unions of near kin, which among primitive races are freely entered into; and we may expect this feeling by and by to cover all unions which, if not consanguineous in name, are so in fact-that is to say, by the physical or mental predisposition of the parties. Many couples are to be found in a large town, or even in a populous parish, who, although not related in blood, are, on account of the similarity of their constitutional defects, as unfitted to marry with each other as the brothers and sisters of a family in which there exists a streak of insanity. We have seen how neglect or ignorance of this principle leads to the deterioration of all exclusive aristocracies and castes. At present not only is the question of the moral fitness of a bride and bridegroom left out of consideration, but there are few people able to learn with certainty anything of the idiosyncrasies of their own grandfathers or grandmothers.

We may look, further, for a strengthening of the existing sentiment in favour of marriages of affection, so that the parent who constrains his son or daughter to make an objectionable match will incur public reprobation. A wholesome contempt is already felt in English middle-class life for people who marry 
for money. In France the mariage de convenance, deeply rooted as it is, cannot indefinitely withstand the hostility of literature and the stage, the frequent condonation of adultery in the works of French novelists and dramatists being in reality an unconscious protest against loveless unions.

The tendencies we have described will favour the equalisation of the sexes before the law. All the civil disabilities of the female sex, having their origin in the stealing, buying, or selling of wives, will disappear ; women will be allowed to dispose of their affections as they will, and to exercise their talents in any profession they may care to take up. Men will continue, however, to govern, by virtue of their greater physical strength and endurance. The necessities of child-bearing will always be a bar to the free exercise by women of political rights. For this reason the sphere of their influence will necessarily continue to be domestic; whence a radical difference between the instincts and sentiments of the two sexes, which the experience of widows or spinsters who may be independent householders and citizens will never modify in any essential degree.

Divorce as understood in England is bound 
to undergo some modification. All attempts to govern the relations of the sexes by mediæval canon law will have to be abandoned, and marriage will come to be regarded even by the Church as a purely civil contract. Despite the fundamental difference in the instincts of the sexes, divorce will probably be procurable by wives and husbands upon precisely equal grounds. These grounds may be expected to vary from time to time, from adultery to mere incompatibility of temper. In this respect the United States of America are passing through an interesting stage of experience. Hardly any two states of the Union regard the question of marriage from the same standpoint. In New York infidelity is the only recognised ground for divorce. In Virginia, however, a marriage may be dissolved if one of the parties is a fugitive from justice; in West Virginia and Kentucky the notorious immorality of a husband before marriage, provided it has been unknown to the wife, is, upon its discovery by her, a valid cause of divorce; while in Illinois, Kansas, Ohio, and Rhode Island relief may be sought by one of the parties to the marriage bond who can allege any gross neglect of duty agaiust the other. Incompatibility of temper is 
taken in the widest sense of the word, and may imply no more, as in Illinois, than that both parties agree to a divorce. Among these various systems it is impossible to decide upon abstract grounds which is the best. Eventually that form of divorce will prevail in America and elsewhere which may be found to be the most expedient. The system finally adopted by every nation will be the one best calculated to safeguard communal as opposed to individual interests.

In social ethics generally we shall probably come to recognise with Maudsley that there are "three great neuroses - the epileptic, the insane, and the criminal." For thousands of years the world has been governed upon the principle that man is morally a free agent-free to practise vice or virtue as he chooses. We pity the hunchback, and we have nothing but execration for the drunkard or the thief. We have but one law for the rich and the poor, the enlightened and the ignorant. In the case of insanity alone is any allowance made for moral. irresponsibility. The lunatic who murders his fellow is not sentenced to death, but ordered to be confined during Her Majesty's pleasure. Yet the criminal who comes into conflict with the law again and again 
through an hereditary tendency no less inevitable than insanity is subjected to an increase of punishment for every fresh offence. We read of miserable men and women who have made repeated appearances in a court of justice, and who have passed two-thirds of their lives in prison. Some day the law will recognise that these wretched beings are not criminals in the true sense of the word, but modified lunatics, and will deal with them accordingly. In the light of heredity, the administrative methods of Christianity itself appear to call for revision. Religion has ceased in a great measure to concern itself with the cure of the maimed, the halt, and the blind, and it now becomes a question whether moral defects are not largely to be placed in the same category, and whether the object of philanthropists ought not to be to strike at evil in its germ rather than in its fruits.

It may be that the problems of crime and sin, which have so long baffled law and religion, are not so insoluble after all. Under the enlightened system that we contemplate, all the reforming influences of the world would be brought to bear upon man before he was born and not after. The potter moulds his vessel while his clay is soft, not after it has passed 
through the furnace. In being born man undergoes the firing process, so to speak, which fixes his character for good or evil. That prevention is better than cure will probably become the motto of the churches as well as of the medical schools.

The questions of an hereditary monarchy and a governing aristocracy are of political rather than scientific interest. Like all other questions affecting the welfare of the community, they will eventually be settled by considerations of expediency. On the simple ground of heredity, no royal family or aristocracy in the world occupies a tenable position. Nothing could be more plausible in a scientific sense than the idea of a class moulded of finer clay than the rest of the community; but unfortunately all exclusive castes, as we have seen, have been placed upon a false basis. Not only is the descent of qualities, moral and physical, assumed to occur through males alone, whereas the female exercises equal influence with the male in generation, but a system of intermarriage in a caste tends to the deterioration of the members of that caste, and that by the very operation of the law of heredity, which is supposed to constitute their superiority.

Recent writers have doubted whether our present 
civilisation can be more enduring than the great civilisations of the past. "Every family, every people, every race," says Ribot, "is born with a certain measure of vitality, a given amount of physical and moral aptitudes which time and circumstances bring to light. The evolutionary process lasts until the family, the people, or the race has accomplished its destiny, which is brilliant for a few, remarkable for many, obscure for the greater number. As soon as their stock of vitality and aptitude is exhausted, the deterioration of the family, the people, or the race sets in and steadily augments, annihilation finally supervening, unless warded off by some external cause. In this process of decay heredity acts indirectly; the direct cause is to be sought in climate and other physical conditions, and in the manners, customs, and institutions of the community." 1 Jacoby is equally pessimist in his views. "From the great mass of humanity," says this authority, "individuals, families, and races rise above the common level; they laboriously climb the heights of power, riches, intelligence, and talent, and having gained the summit are precipitated once more into the depths. . . . Nations exhaust themselves like soil that is not manured, the

1 Ribot, L'Hérédité Psychologique. 
product of their genius not being returned to the common fund, but being lost to them in a material sense. Thus is explained the phenomenon known to history as the old age and decrepitude of nations. By the operation of selection and the fatal law of the extinction of privileged races, certain peoples become civilised, rise to greatness, then decline and disappear, to be supplanted by younger peoples in whom the selection of talents and energies is barely begun. ... In lowering all who lift themselves above the common level of humanity, in chastising the proud, and avenging the excess of their happiness, Nature makes the privileged classes their own executioners. Too much prosperity offends the gods, said the ancients; and a medical study of the results of all social and intellectual distinction, and selection generally, has led us to the same conclusion." I

The true moral to be drawn from the passages above quoted is the danger of metaphor in discussing a scientific subject. These laboured comparisons of the race with the individual we believe to be wholly misleading. Nations, it is true, have risen and fallen, civilisations have grown up and declined; and in the European communities of the present day causes of

1 Jacoby's Éludes sur la Sélection. 
deterioration are at work which if unchecked would probably bring upon us the fate that overtook the Greeks and the Assyrians. While improving our methods of sanitation, we carefully rescue from the fate that would await them in a ruder society the weak, the vicious, and generally the unfit, and, thanks to our philanthropy, they are enabled to throw their defects into general circulation. Hurtful to the general interest also is our indiscriminate worship of wealth, with the many unsuitable marriages it entails. Finally, class selection, upon the evils of which Jacoby so justly insists, and which prevails in the commercial as well as in the upper classes-in every form of social cliquism, in fact-is a constant and fruitful source of social degeneration. But if evolution means anything at all, it means that Nature does not move in a vicious circle, but, with many halts, much harking back, many false steps, perhaps, keeps in the main advancing. We cannot fairly judge of her progress within the paltry two thousand years covered by anthentic history. It takes an infinitely longer period to work the simplest figure in the warp and woof of existence. In the great web of life, which the Erdgeist of Goethe is ever weaving, there are many broken threads, many imperfect designs. 
But we can at length perceive something of its general pattern; nay, to adopt the vigorous simile of Professor Tyndall, we can even catch glimpses of the flying shuttle. The decay of the peoples and civilisations of the past was due to causes which we are now beginning to understand, and our growing knowledge upon that point, together with the remedies it may enable us to adopt, is in itself to be regarded, perhaps, as a feature of evolution.

Speculation is still free to deal as it pleases with those wider questions, What are we? and Whither do we tend? "Here we drift," says Emerson, "like white sail across the wild ocean, now bright on the wave, now darkling in the trough of the sea; but from what port did we sail? Who knows? Or to what port are we bound? Who knows? There is no one to tell us but such poor weather-tossed mariners as ourselves whom we speak as we pass, or who have hoisted some signal or floated to us some letter in a bottle from afar. But what know they more than we? They also found themselves on this wondrous sea. No; from the older sailors nothing. Over all their speaking trumpets the gray sea and the lond winds answer - Not in us; not in Time." At the risk of spoiling this beautiful figure we would add, 
for the sake of enforcing the truth we have sought to expound, that whatever our destination as mariners may be, we may at least advantageously learn something of the principles of navigation. By that means we shall avoid being helplessly driven to and fro by adverse currents, and more speedily gain the brighter latitudes that lie alead. 




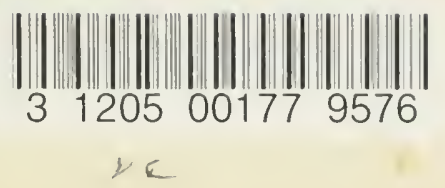

UC SOUTHERN REGIONAL LIBRARY FACILITY

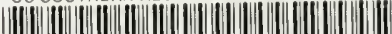

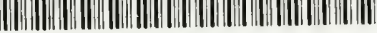
AA $000588245 \quad 1$ 
